San Jose State University

SJSU ScholarWorks

Master's Theses

Master's Theses and Graduate Research

2004

\title{
Evaluation of a monitoring program for detecting oiled birds on beaches
}

Karna Carlson

San Jose State University

Follow this and additional works at: https://scholarworks.sjsu.edu/etd_theses

\section{Recommended Citation}

Carlson, Karna, "Evaluation of a monitoring program for detecting oiled birds on beaches" (2004).

Master's Theses. 2650.

DOI: https://doi.org/10.31979/etd.k36a-5j5r

https://scholarworks.sjsu.edu/etd_theses/2650

This Thesis is brought to you for free and open access by the Master's Theses and Graduate Research at SJSU ScholarWorks. It has been accepted for inclusion in Master's Theses by an authorized administrator of SJSU ScholarWorks. For more information, please contact scholarworks@sjsu.edu. 


\section{NOTE TO USERS}

This reproduction is the best copy available.

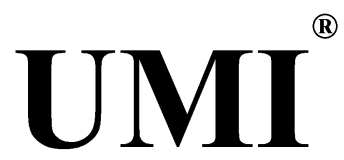





\title{
EVALUATION OF A MONITORING PROGRAM FOR DETECTING OILED BIRDS ON BEACHES
}

\author{
A Thesis \\ Presented to \\ The Faculty of the Department of Environmental Studies \\ San Jose State University \\ In Partial Fulfillment \\ of the Requirements for the Degree \\ Master of Science \\ by \\ Karna Carlson \\ December 2004
}


UMI Number: 1425452

Copyright 2004 by
Carlson, Karna

All rights reserved.

\section{INFORMATION TO USERS}

The quality of this reproduction is dependent upon the quality of the copy submitted. Broken or indistinct print, colored or poor quality illustrations and photographs, print bleed-through, substandard margins, and improper alignment can adversely affect reproduction.

In the unlikely event that the author did not send a complete manuscript and there are missing pages, these will be noted. Also, if unauthorized copyright material had to be removed, a note will indicate the deletion.

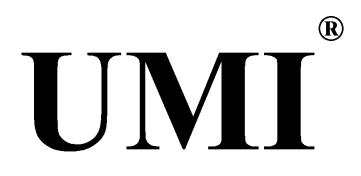

UMI Microform 1425452

Copyright 2005 by ProQuest Information and Learning Company.

All rights reserved. This microform edition is protected against unauthorized copying under Title 17, United States Code.

ProQuest Information and Learning Company 300 North Zeeb Road

P.O. Box 1346

Ann Arbor, Ml 48106-1346 
(C) 2004

Karna Carlson

ALL RIGHTS RESERVED 


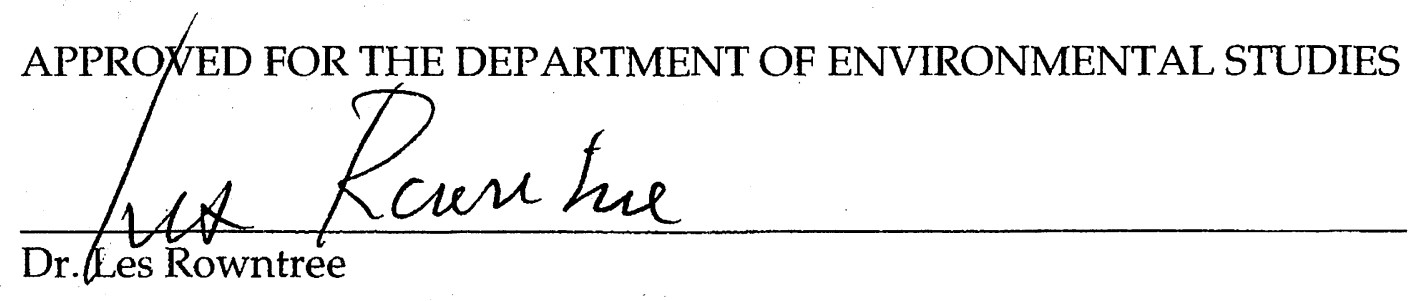

hype Julia

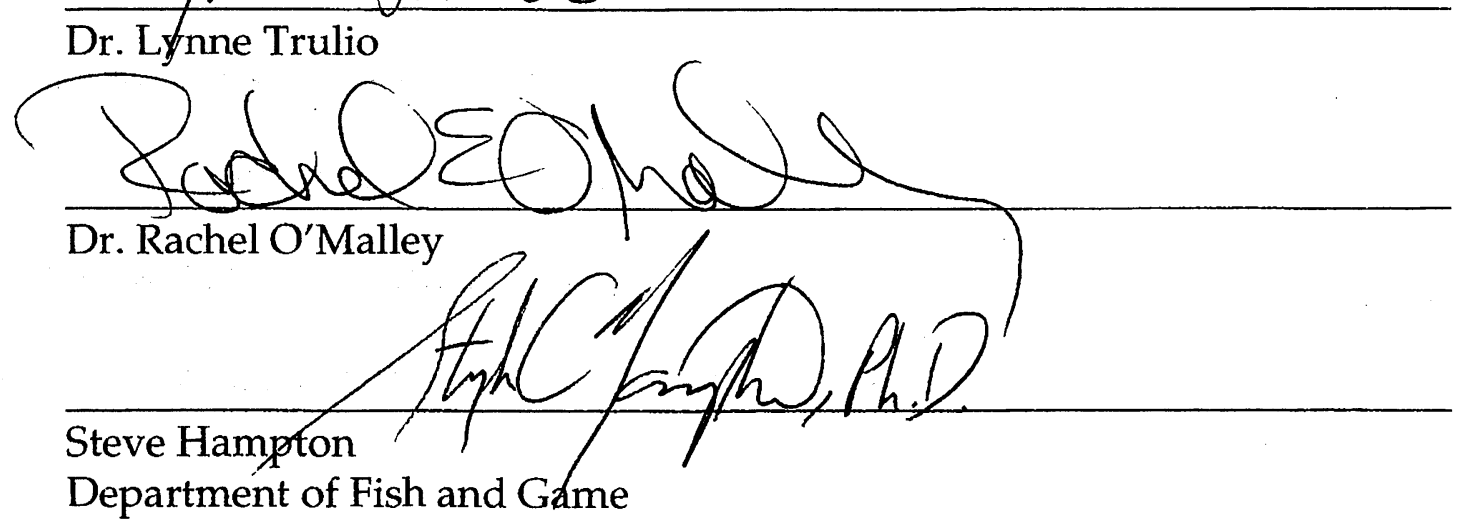

Department of Fish and Game

APPROVED FOR THE UNIVERSITY

Thea T. Whlhamson- 


\title{
ABSTRACT \\ EVALUATION OF A MONITORING PROGRAM FOR DETECTING OILED BIRDS ON BEACHES
}

\author{
By \\ Karna Carlson
}

This thesis research analyzed the quality of data and program structure of a monitoring program for detecting oiled birds. The Department of Fish and Game organized a beach search effort and between December 2002 and January 2003 survey teams looked for oiled birds along the central California coast. The goal of the beach search effort was to produce data that would estimate the total number of birds impacted by a sunken leaking freighter. Searchers used five methods to locate birds, none of which yielded an accurate number of birds or trends for estimating total bird losses. Problems included protocols that were not specifically designed to achieve this goal and data recording that had many errors.

This analysis found that for foot surveys, searchers needed to spend approximately 100 minutes if they were to find birds. Recommendations for designing a monitoring program that provides reliable, quantitative data are provided. 


\section{ACKNOWLEDGEMENTS}

I would like to recognize the support of Dr. Les Rowntree for always providing me guidance and perspective throughout my graduate studies efforts;

Dr. Rachel O'Malley for guiding me through the appropriate research methodologies; Dr. Lynne Trulio for bringing renewed clarity and energy to the research process, and to Steve Hampton of the California Department of Fish and Game, Office of Oil Spill Prevention and Response, for providing the S.S. Jacob Luckenbach data and research support.

I would also like to thank William Normark and Florence Wong of the United States Geological Survey for converting the beach segment global positioning system coordinates into meters and mapping those beach segments with start and end points. I also wish to thank Gerry Uenaka for his technical assistance with the development of the in-text research figures and technical support of the thesis defense power point presentation.

My appreciation also goes to Christian C. Elias of the Santa Clara Valley Water District for his support and encouragement of my graduate studies and approval for the needed time from work to complete this thesis.

Finally, I dedicate this thesis mother and father for their unconditional love and encouragement. 


\section{TABLE OF CONTENTS}

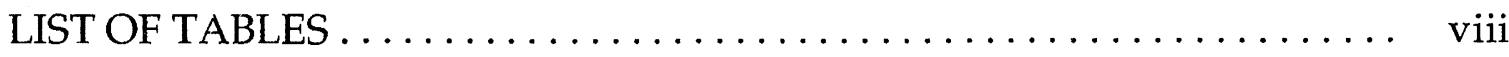

LIST OF FIGURES $\ldots \ldots \ldots \ldots \ldots \ldots \ldots \ldots \ldots \ldots \ldots \ldots \ldots \ldots \ldots \ldots \ldots \ldots \ldots$

\section{Chapter}

INTRODUCTION

Background $\ldots \ldots \ldots \ldots \ldots \ldots \ldots \ldots \ldots \ldots \ldots \ldots \ldots \ldots \ldots \ldots \ldots$

Objectives................................ 6

RELATED RESEARCH

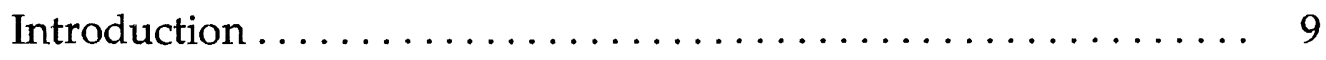

Program Development and Implementation

Considerations ............................... 10

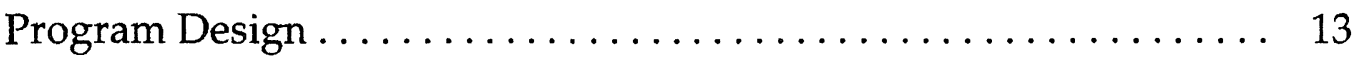

Data Sampling and Analysis ..................... 17

Collaborative Research $\ldots \ldots \ldots \ldots \ldots \ldots \ldots \ldots \ldots \ldots \ldots, 18$

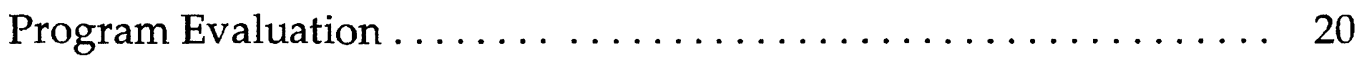

Barriers to Program Development and Implementation $\ldots \ldots \ldots \ldots \quad 23$

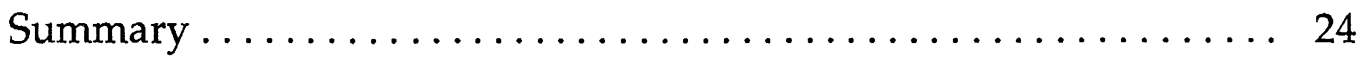

\section{METHODS}

Introduction $\ldots \ldots \ldots \ldots \ldots \ldots \ldots \ldots \ldots \ldots \ldots \ldots \ldots \ldots \ldots \ldots \ldots \ldots, 25$

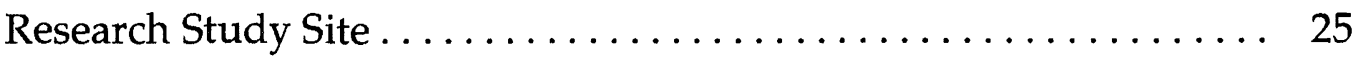

S.S. Jacob Luckenbach Beach Search Effort ................ 27 
Thesis Research Design and Data Analysis ... . . . . . . . . . . . 32

Research Assumptions and Limitations . . . . . . . . . . . . . 34

RESULTS .................................. 36

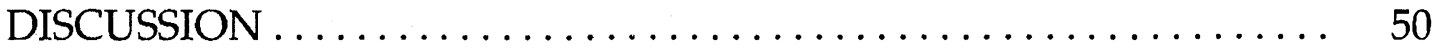

RECOMMENDATIONS ....................... 57

REFERENCES ............................... 60

\section{Appendix}

Beach Search Effort Logs . . . . . . . . . . . . . . . . . 64

Summary of Raw Beach Search Effort Data .............. 65

Map of Beach Segments Searched $\ldots \ldots \ldots \ldots \ldots \ldots \ldots \ldots \ldots \ldots$ 


\section{TABLES}

Table

1. S.S. Jacob Luckenbach Beach Search Effort Field Methods . . . . . . . . . . 27

2. Foot Search Method Results Comparing Data When Birds Found and Not Found $\ldots \ldots \ldots \ldots \ldots \ldots \ldots \ldots \ldots \ldots \ldots \ldots \ldots \ldots \ldots, 38$

3. Combination Foot/Point Scan Search Method Results Comparing When Birds Found and Not Found .................... 39

4. Percent of Cases in Which Birds Were Found by Search Method. . . . . 40

5. Essential Monitoring Program Components ............... 41

6. Methodological Changes Needed in the S.S. Jacob Luckenbach Beach Search Effort............................. 49 


\section{FIGURES}

Figure

Page

1. Location of Sunken Freighter off the Central California Coast ....... 3

2. Photo of the S.S. Jacob Luckenbach ....................... 4

3. Computer Model of Sunken Freighter on Ocean Floor $\ldots \ldots \ldots \ldots, 6$

4. Total California Coastal Region Searched for Oiled Birds ......... 7 


\section{INTRODUCTION}

\section{Background}

Marine ecosystem protection is the outcome of on-going public concern and government response. Threats to marine environments include over-fishing, harvesting, mining, drilling, pollution, oil spills, debris, and recreation.

Designating marine sanctuaries along the U.S. coastline is one way governments have tried to protect marine habitats (McGregor 1994). Marine sanctuary development began after 1972 when Congress passed the Marine Protection, Research and Sanctuaries Act (Act) (McGregor 1994). The Act authorized the National Marine Sanctuaries Program and empowered the U.S. Secretary of Commerce to designate sanctuaries and promote comprehensive management of their uses, such as, conservation, recreation, research and education, and aesthetic resources (NOAA 1999). The first marine sanctuary, the U.S.S. Monitor National Marine Sanctuary, was designated in 1975.

The Act requires sanctuary managers to develop a plan for managing each sanctuary's natural and cultural resources. Sanctuary managers, working within the Sanctuaries and Reserve Division of the Office of Ocean and Coastal Resources Management, a division of the National Oceanic and Atmospheric Administration (NOAA), work collaboratively with the public, grassroots organizations, local, state, and federal governments, researchers, and industry to 
develop such plans. As part of these plans, sanctuary managers must prepare for emergencies by developing sanctuary contingency plans for various disaster scenarios and to coordinate response efforts between local, state, and federal agencies. To complement contingency plans, sanctuaries may also implement on-going monitoring efforts to survey coastal beaches for oil spills, collecting baseline data on spill locations, including dead and injured marine animals and habitats, to aid in response and restoration by incident commanders, resource agencies, and litigators. The collected data provide a tool for assessing ecosystem health, developing policy and identifying funding priorities, supporting litigation in cases of human induced disaster, and promoting public accountability.

Significant oil spill events, for which monitoring has become increasingly important, are the result of a sunken freighter that sank off the coast of the San Francisco Bay in 1953. For decades, intermittent oil spills have polluted California's central coast and killed large numbers of marine birds. For many years, the source of the oil was unknown. In 2001, the U.S. Coast Guard finally identified the oil source as the sunken freighter, the S.S. Jacob Luckenbach (Hampton et al. 2003), which sank on July 14, 1953, seventeen miles southwest of the Golden Gate Bridge and ten miles southeast of the Southeast Farallon Island (McCleneghan 2002) (Figure 1). The S.S. Jacob Luckenbach was a C-3 freighter built in 1944 and left San Francisco en route to South Korea loaded with 10,880 barrels 
(457,000 gallons) of bunker fuel (Hampton et al. 2003), railroad and automotive parts, and other materials to support the Korean War (McCleneghan 2002)

(Figure 2). As the freighter traveled out of the San Francisco Bay, it was struck near its stern by the S.S. Hawaiian Pilot and sunk in an estimated 175 feet of water.

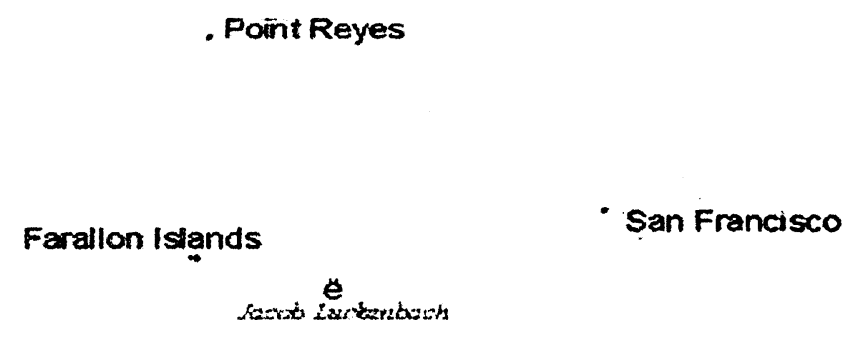

- Half Moon Bay

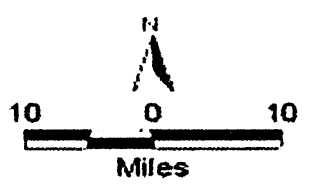

Santa Cruz

Figure 1: Location of Sunken Freighter off the Central California Coast (California Department of Fish and Game) 


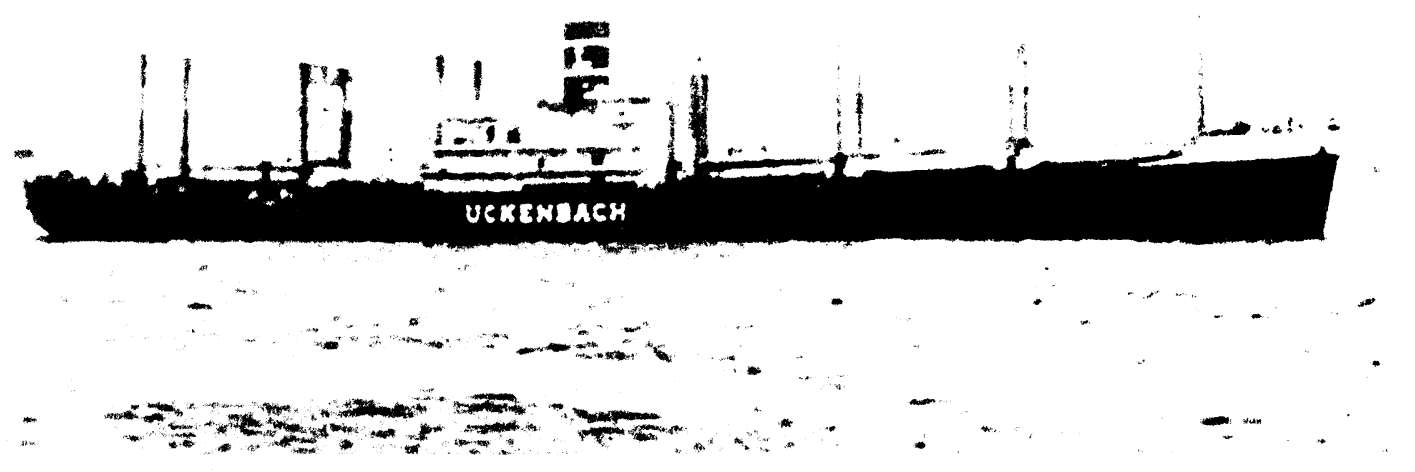

Figure 2: Photo of the S.S. Jacob Luckenbach (California Department of Fish and Game)

The eroding S.S. Jacob Luckenbach hull is now considered the source of many mysterious, intermittent releases of oil since the 1970's, impairing the coastline and marine birds during the significant storm events that are common during the late fall and winter months (McCleneghan 2002) in the San Francisco Bay region. If assumed to be leaking since settling to the ocean floor in 1953, over time, the S.S. Jacob Luckenbach is estimated to be responsible for the deaths of tens of thousands of marine birds (Hampton et al. 2003), including Common Murres on the Southeast Farallon Island (Carter et al. 2003).

Government response to, and documentation of, oiled bird events was limited prior to the 1990's (Hampton et al. 2003). In November 2001, after another significant oiled marine bird event along the central coast shoreline, mostly 
affecting Common Murres, the California Department of Fish and Game's Office of Oil Spill Prevention and Response (OSPR) and the U.S. Coastguard, Marine Safety Office, San Francisco (USCG), initiated a coordinated oil spill response effort (McCleneghan 2002).

After discovering and locating the final resting place of the S.S. Jacob Luckenbach, divers successfully pumped over 100,000 gallons of fuel from the sunken freighter (McCleneghan 2002) (Figure 3). However, the impact of oiling on the local Common Murre colonies continues to be significant, since greater than ninety-five percent of the breeding population (Hampton et al. 2003) nest on the Farallon Islands during the winter. Since no responsible party exists to pay for the cleanup efforts of the S.S. Jacob Luckenbach, the USCG's National Pollution Funds Center authorized the use of the Oil Spill Liability Trust Fund (Fund), created under the Oil Pollution Act of 1990, to pay for clean-up and compensatory restoration costs (Hampton et al. 2003). Compensatory restoration costs repay the public for injuries to natural resources, such as losses to marine bird populations. Natural resource trustee agencies may pursue this compensation by filing a natural resource damage claim to the Fund using a natural resource damage assessment. In the case of the S.S. Jacob Luckenbach's impacts to oiled birds, agencies must quantify the number of injuries (Hampton et al 2003) by determining the accurate number of beached birds, injured or dead. 


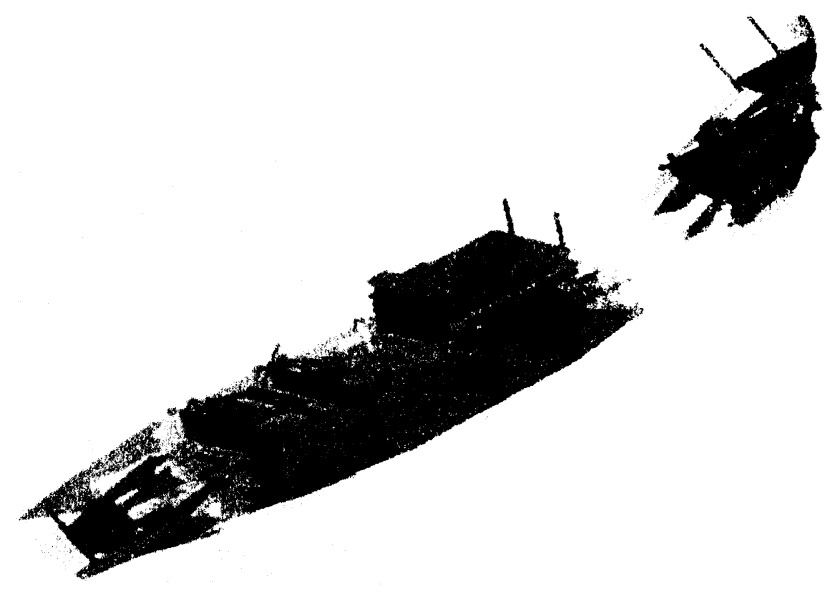

Figure 3: Computer Model of Sunken Freighter on Ocean Floor (California Department of Fish and Game)

Few coastal monitoring programs exist and little information is available to design an ideal model for a monitoring program. Although authors individually theorize about the important components of monitoring programs, few recommend a comprehensive model to guide researchers and government agencies in the development of effective data collection efforts.

\section{Objectives}

This thesis research analyzes the oiled bird data collected by searchers for the California Department of Fish and Game's Office of Oil Spill Prevention and Response between December 2002 and January 2003 along the California 
coastline, between the central Sonoma and central Monterey counties (Figure 4), and the survey protocols for that effort.

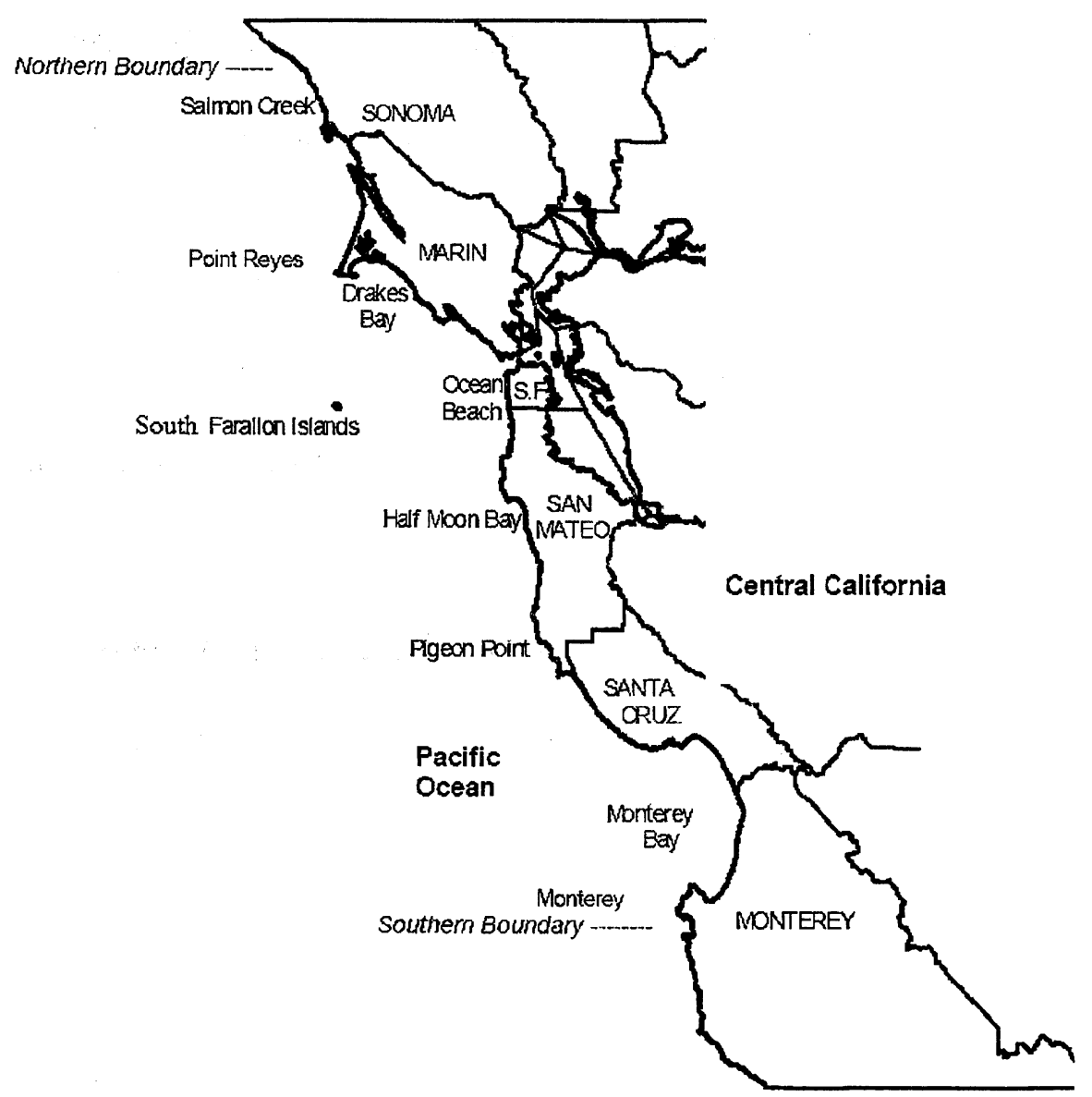

Figure 4: Total California Coastal Region Searched for Oiled Birds (California Department of Fish and Game) 
This analysis is designed to address three research questions:

1. What can be inferred about the rate of oiled birds from the S.S. Jacob Luckenbach beach search effort data? Do the data meet the goals of the beach search effort to estimate the total number of birds impacted by the S.S. Jacob Luckenbach?

2. According to the literature, what are the essential components of a reliable monitoring program designed to produce quantitative data?

3. How can the S.S. Jacob Luckenbach beach search effort be changed to be a reliable program that meets the criteria developed for research question \#2? 


\section{RELATED RESEARCH}

\section{Introduction}

Monitoring studies used to assess management practices of protected ecosystems convey a program's effectiveness to fulfill the ecological, policy, and funding goals of managers, policymakers, and the public (Epstein 1995, Griffith 1998, Hockings 1998, Lee 1996, Ringold et al. 1999, Sherman 1994, Smith-Evans and Dawes 1997, and Vora 1997). Data collected from these studies communicate to managers changes in ecosystem health, resource availability, and system trends, whether those changes are human induced, such as oil spills or logging practices, or naturally occurring, like earthquakes or volcanic eruptions (Rees and Pond 1995; Vora 1997; Malone and Nemazie 1996; Gilfillan et al. 1999; and Ringold et al. 1999). However, monitoring is still an expanding ecosystem assessment application. Monitoring programs should also provide accurate and quantified assessments of ecological condition. Social and natural scientists continue to examine program development and implementation, appropriate monitoring parameters, study design, institutional research, and program barriers. Although not exhaustive, this literature review examines the various aspects of monitoring programs analyzed and discussed by scientists. 


\section{Program Development and Implementation Considerations}

Monitoring surveys are just one of elements needed to evaluate ecosystem health (Vora 1997). Assessing health also includes conducting broad baseline inventories (Agnew 1997, Krogh and Koop, Ogden et al. 1994, and Lee and Pritchard 1996); defining goals and objectives for ecosystems of varying scales (Vora 1997 and Griffith 1998); identifying observable or measurable key indicators that can be used to answer assessment questions (Agnew 1997); determining the specific thresholds, values, ranges and endpoints for individual indicators; designing a monitoring program (Nelson 1993 and Ogden et al. 1994); monitoring identified indicators to detect status relative to identified diagnostic thresholds (Agnew 1997 and Malone and Nemazie 1996); and evaluating results (Nelson 1993 and Green 1979).

Researchers outline different theories behind the development and implementation of a monitoring program (Griffith 1998, Natural Resources Defense Council 1999, Wells 1999, and Ringold et al. 1999). Griffith (1998), for example, gives four reasons monitoring programs are developed: 1) To determine the present and future health of ecosystems; 2) To establish empirical limits of variation of natural resources; 3) To diagnose abnormal conditions and identify issues in time to develop effective mitigation, and 4) To identify potential agents of abnormal change. The United States Natural Resources Defense Council (NRDC) similarly believes that monitoring programs are 
important to develop and implement because they 1) provide information needed to evaluate pollution abatement problems, 2) serve as early warning systems that lower cost solutions to environmental problems, 3) contribute to knowledge of ecosystems and how they are affected by human activity, 4) provide essential data for the construction, adjustment, and verification of quantitative predictive models, which are an important basis for evaluating, developing, and selecting management strategies and, 5) provide environmental managers the scientific rationale for setting environmental quality standards.

Wells (1999) also argues that periodic assessments of oceanic and marine ecosystem health and quality are essential because they reveal the current conditions and trends, especially of the problems, within these systems. These also provide environmental managers with reference points for setting priorities in controls, regulations, new developments, and research. The resulting data provide a focal point for questions, such as: What are the existing problems? How well are they understood? Are they getting better or worse? Long-term monitoring can provide trend data, especially on population change and distribution, occurrences of environmental pollution, the success of rehabilitation and restoration projects, and demographic changes taking place in the coastal zone.

However, Ringold et al. (1999) emphasize that in assessing ecosystem health, scientists must also evaluate a monitoring program's effectiveness. For example, 
programs should be assessed to determine whether the objectives of the plan are being achieved; whether steps of the plan are being implemented; and whether the assumptions underlying the plan are correct.

Monitoring programs for ecological health have been established on national and local scales. One example of a national program is the U.S. Environmental Protection Agency's (EPA) Environmental Monitoring and Assessment Program (EMAP). The need to develop a more effective, large-scale, monitoring program was recognized early by the EPA (EPA 1996). In 1988, the U.S. EPA's Science Advisory Board made several recommendations to the EPA to strengthen its research on the condition of the environment. As a result, EMAP was developed, with the goal to "monitor the condition of the nation's ecological resources to evaluate the cumulative success of current policies and programs and identify emerging problems before they become widespread or irreversible" (EPA 1996). This program can be used to confirm that the nation's environmental protection programs are maintaining or improving the quality of the environment (Messer et al. 1991). EMAP's goal is applicable to evaluating the status of all protected ecosystems, including coastal systems.

Despite this large-scale effort, the NRDC found that there are significant stretches of California coastline without water quality monitoring efforts. In their annual report, "Testing the Waters - 1999 A Guide to Water Quality at Vacation Beaches", the NRDC concluded that many swimming waters remain 
unmonitored along the coast and are threatened by pollution. Recognizing the need for coastal monitoring, California passed a law in 1997 mandating the monitoring of beaches beginning in 1999; to date, regulations are not in place to enforce the law. The NRDC, in their recommendations, suggests the EPA expand the monitoring efforts of their Beach Environmental Assessment, Closure and Health $(\mathrm{BEACH})$ Program. However, there is concern that large, nationwide programs, intended to oversee all environmental monitoring, diminish their purpose and effectiveness when these monitoring efforts could be conducted locally, thus reducing the occurrence of turf battles between local and national agencies (Griffith 1998).

\section{Program Design}

Authors agree that a successful monitoring program is one in which its purpose and goals are clearly identified (Griffith 1998, Ringold et al. 1999, Vora 1997). Vora (1997) makes the case that monitoring should not be carried out until its design objectives, scope, and data reliability have been defined, taking note that data results should assess and communicate the effects and effectiveness of management practices. Additionally, Griffith argues that monitoring programs

should be designed to address a set of hierarchical questions: 1) Purpose: What is the aim of monitoring? 2) Method: How can this be achieved? 3) Analysis: How are the data, which will be collected periodically, to be handled? 4) 
Interpretation: What does the data mean, and 5) Achievement: When will the goal be achieved?

Nelson (1993) reviewed general and specific sampling design considerations. Four general conditions needed to achieve an "optimal impact study design" (Green 1979). In the case of beach restoration monitoring, these are: 1) collection of pre-impact baseline data; 2) determination of the type of impact (e.g., oil spill) and its time and place of occurrence; 3) simultaneous measurements of all relevant biological and environmental variables; and 4) identification of a control site. It is very difficult to develop statistically analyzable data with impact monitoring studies because it is impossible to randomly assign a particular treatment effect to a particular location, intersperse two types of treatments, and identify sample sites that are true treatment replicates. Using inferential statistics to analyze beach restoration, for example, remains problematic for these reasons (Nelson 1993). Instead, the investigator must be cautious with monitoring observations so that random events do not impinge solely on the replicates of one treatment.

Statistical validity can be achieved with Before and After Control Impact (BACI) designs. This technique requires multiple control sites to determine ranges of natural variation. Monitoring programs meant to determine human impacts to certain sites from unique events should try to implement a BACI design. Monitoring should incorporate long-term sampling. In Lee and 
Pritchard's (1996) analysis of long-term patterns in time-limited environmental monitoring programs, the entire study focused on BACI and data was thus collected accordingly - before and after an impact at replicated control and impact locations. Thus the authors caution against making assessments in the absence of long-term data sets, especially if stochastic events (e.g., floods and fires) are not always consistent. Furthermore, Ogden et al. (1994) also make the case for long-term research, confident it will ultimately manage human impact if conducted over a time scale that incorporates variation in ecosystems, processes, and geography.

Ultimately, monitoring design to evaluate ecosystem health should be adaptive and flexible (Ringold et al. 1999). Scientists must consider the practicality of assessing an entire ecosystem. In some instances, program objectives require assessing only one parameter of an ecosystem. Thus, an indicator species, a dependent or related species likely to reflect changes in the availability of certain fauna resources, indicating the state of that part of the ecosystem most impacted by stochastic or planned activities, can be used as a monitoring tool of ecosystem health (Agnew 1997).

Monitoring programs may require changing priorities altogether to recognize changed circumstances. Armstrong et al. (1996) examine Sydney, Australia's need to change the priorities of their Beachwatch Pollution Monitoring Programme. Sydney's local officials decided to take advantage of deep ocean 
currents to keep sewage away from public beaches and replaced their near-shore, cliff sewage outfalls with offshore, deepwater diffusers. As a result, the program's surveys went from monitoring impacts of gross sewage pollution to more diffuse pollution created offshore.

Several researchers have assessed the design of beach debris monitoring programs. Rees and Pond (1995) assess marine debris monitoring programs. They outline three methods used to collect debris data and evaluate the effectiveness of each method. The first collection method requires mathematical extrapolation by multiplying the number of people at sea in a given activity by the average amount of litter produced by that activity. The second approach uses transect lines from sides of research boats, counting the density and type of debris along that transect. The final approach uses volunteers and beach monitoring surveys to collect data. The authors conclude that the beach survey method is the most appropriate method because it allows a large sample size to be monitored cost-effectively and with minimal equipment. Furthermore, variations on beach sample surveys are versatile enough for varying baseline studies, trend assessment, and assess land-based and ocean-based litter.

Gilfillan et al. (1999) also examine study design in their comparison of Exxon Valdez oil spill monitoring programs. They evaluated three study designs and their statistical power by comparing programmatic elements. The first approach was designed to assess the injury and recovery of wildlife in the entire spill zone; 
the second had a similar objective but focused only on moderate-to-heavily oiled shores; and the third determined the effect of hot-water cleanup techniques on shoreline biota. The researchers concluded that the number of sampling sites in the design of an oil spill study should be as high as possible; second, the statistical power to detect oiling impacts can be increased by selecting the oiled sites from only the most heavily oiled locations; and third, researchers need to evaluate for an ecosystem the pros and cons of different ways of minimizing variance.

\section{Data Sampling and Analysis}

Program design affects data sampling and analysis. In the case of biological monitoring design for beach restoration efforts, Nelson's (1993) analysis specifies that monitoring designs may not always be constructed to meet the individual biological requirements of a given area; therefore detailed baseline studies are required. However, Andrew and Mapstone (1987) argue against standardization of sampling in study design, but Nelson (1993) agrees that some consistency in sampling and methodology would provide data from which conclusions can be drawn concerning general biological impacts of beach restoration.

Krogh and Koop (1996) identify the requirements necessary to yield effective data and analysis. First, treatment comparisons should be as free as possible from systematic error, second, conclusions should have a wide range of validity, 
and third, uncertainty in conclusions should be accessible. The authors emphasize that a good experiment is one which includes clear hypotheses, appropriate experimental design and statistical tests, careful consideration of the parameters to be measured, power of the study to detect statistical and ecological differences, appropriate choice of control sites, and adequate pilot studies. Effective sampling and analysis is also a condition of knowing how many samples in a given site yield effective results, using fixed versus variable sample sites along a transect, the type of equipment to procure data, and knowing when and how long to conduct sampling at a site (Nelson 1993).

\section{Collaborative Research}

Monitoring success also depends on a collaborative effort to effectively and efficiently gather and share data (Agnew 1997, Epstein 1995, Malone and Nemazie 1996, Ogden et al. 1994). In Agnew's review of the Commission for the Conservation of Antarctic Marine Living Resources Ecosystem Monitoring Programme, an argument for parallel programs of research and monitoring is made. As a result, monitoring can be modified with changing requirements and produce a strong scientific background for the interpretation of results. While the program monitored for mortality among Adelie penguin chicks on Bechervise Island, Antarctica, associated research demonstrated that krill scarcity in the 
island's vicinity was the culprit. Collaborative work in this research thus yielded more robust results.

The connection between environmental change and its effect on the global resurgence of infectious disease also warrants coordinated research efforts (Epstein 1995). Although the link between environment and health may be direct or indirect, a major impediment to disease monitoring and detection is the fragmentation of epidemiology and scientific disciplines. However, with the development of geographically displayed data, new opportunities exist for multi-disciplines to coordinate their results and overlay data sets. Epstein (1995) concludes that risk assessment of anthropogenic activities must include ecological effects to ensure that indirect human effects on the environmental quality do not exacerbate disease.

Malone and Nemazie (1996) also emphasize the need for collaboration and data sharing between scientists, especially as ecosystem research has significantly increased at a time when ecosystems are being lost or degraded at accelerating rates, meanwhile government agencies are sponsoring costly monitoring programs and research publications. They further reason that the gap between national needs and the capacity of the nation's research institutions grows rapidly, thus making a case to strengthen the role of coastal laboratories to address the problems affecting coastal ecosystems. The authors suggest that the success of laboratories is in their willingness to work with federal agencies to 1) 
overcome parochial attitudes and approaches - labs and agencies should no longer work independently in jurisdictions they believe to be solely theirs; 2) develop and coordinate research and monitoring programs to make optimal use of resources; and 3) respond to new demands and expectations. Malone and Nemazie (1996) further believe that coastal laboratories are in a position to 1) promote scientific programs at the local, regional and national level and 2) facilitate consensus among scientists and stakeholders. Finally, the authors stress the importance of laboratories and federal agencies to share resources and form coalitions to develop relevant and cost-effective research in the coastal zone.

A final example is the long-term study of the Florida Keys seascape. Ogden et al. (1994) concluded that effectively documenting and understanding changes to ecosystem health means integrating research across disciplines, incorporating geographic and temporal scales of natural ocean processes upon which human impact is superimposed. Therefore, it is concluded that effective data management and trend analysis in monitoring programs must consider interdisciplinary coordination.

\section{Program Evaluation}

Ecosystem management plans, although widely developed and implemented, often lack an evaluation component (Hockings, 1998). Although formal evaluation plans are considered and developed for larger agency programs, they 
remain the exception for small, individualized protected areas and management plans.

Much of the literature outlines the ways in which monitoring programs should be developed and implemented (Griffith 1998, Smith-Evans and Dawes 1997, Vora 1997). Few critique and evaluate a monitoring program's power, or effectiveness to produce desired results (Gilfillan et al. 1999).

In one program evaluation, Gilfillan et al. (1999) compared the study design, analysis methods, and statistical power of three shoreline assessment programs, used in the aftermath of the Exxon Valdez spill, which assessed the effects of oil and cleanup techniques in the spill zone of Prince William Sound, Alaska. These programs were 1) the Shoreline Ecology Program (SEP) conducted by Exxon; 2) the Coastal Habitat Injury Assessment (CHIA) conducted for the Exxon Valdez Oil Spill Council; and 3) the Biological Monitoring Study (BMS) conducted for the National Oceanographic and Atmospheric Administration (NOAA).

First, the objectives and study designs were compared in a table based on the following program components: Objective, Experimental unit, Number of sites, Habitats, Oiling levels, Cleanup, Transects per site, Sample stations. Next, the authors outlined the analysis methods comparing each of the programs' comparison units, covariates, population distribution, statistical methods, and significance level. Once the authors outlined the programs based on objectives, study design, and analysis methods, they set out to establish the programs' 
ability to effectively detect the impact of the oil, also known as a program's "power." The authors establish that design differences affect the ability of each program to detect the impact of oil. Therefore, the studies' power was calculated as a function of the number of sites in the design, the signal-to-noise level in the data, and the analysis method. Data were calculated by taking the site and transect numbers for the bedrock habitat assessed in each study. A series of signal-to-noise ratios (treatment mean square per the error mean square) were used to compute various design/analysis scenarios. The authors then compared the power curves of the various signal-to-noise ratios and discussed that the number of sites in an assessment plays a large role in achieving a high power to detect oil spill impacts. They concluded that several strategies be implemented in detecting spill impacts: 1) the number of research sites should be as high as possible to take into account data variation; 2) the sites researched should be heavily oiled locations, suggesting that if a program's objective is to determine that damage did occur, a well oiled site will reveal that data;3) the pros and cons of different ways to minimize variance (e.g., matched-pair design; matching the same physical attributes for control and oiled sites) for a particular environment should be evaluated. 


\section{Barriers to Program Development and Implementation}

Establishing monitoring programs to determine ecosystem health is complex as scientists, politicians, and managers, must agree on its various aspects.

Ringold et al. (1999) identify three barriers in monitoring design and implementation to be addressed for a successful program. These barriers are: the lack of clear objectives (refining existing qualitative objectives must be

continuous), inconsistent, changing, or nonexistent methods (methods must exist and be consistent between organizations and agencies), and the lack of available information to estimate variability of environmental features and measurement error over relevant temporal and spatial scales (effective and relevant ecological indicators must be identified to assess the quality of the environment) (Griffith 1998).

Additionally, the inability to discriminate between natural variation and human induced changes is a major problem in marine ecosystem research (Ogden et al. 1994). Natural processes vary on a time scale different than research funding cycles; thus collecting long-term ecosystem data sets are critical to ecosystem management. $\mathrm{BACI}$ designs and long-term monitoring are needed to address this problem.

Finally, institutional barriers can impact the integrity of an established program. Although some studies require collecting years of data to document long-term environmental effects, changes in government priorities - both 
programmatic and financial - restrict logistically expensive studies, such that only short-term results can be determined (Lee and Pritchard 1996). Social, political, and economic aspects of a monitoring program are clearly integral to the condition and management of the environment, since these are driving forces behind environmental impacts as well the inequitable distribution of these resources to address treatment (Epstein 1995).

\section{Summary}

In the field of conservation management, monitoring programs are increasingly recognized for their importance to determine the condition of the environment and identify the need for future improvements. These programs assist policymakers in policy development and funding decisions and meet expectations of the public's desire for a clean and safe environment (Griffith 1998, Hockings 1998, Ringold et al. 1999). However, once monitoring programs are designed and implemented, they, too, require evaluation to determine whether they are effective in meeting the objectives of their design. Authors (Gilfillan et al. 1999, Griffith 1998, Hockings 1998, and Ringold et al. 1999) agree that the effectiveness of a monitoring program resides not in post-data analyses, but in assessments at all phases of its design. 


\section{METHODS}

\section{Introduction}

This thesis study evaluates the effectiveness of the S.S. Jacob Luckenbach beach search effort conducted between December 2002 and January 2003 to find oiled birds along the central California coast. Searchers representing the U.S. Fish and Wildlife Service, the California Department of Fish and Game's Office of Oil Spill Prevention and Response, the non-profit organization Oiled Wildlife Care Network, and the consulting firm, Mad River Biologists, gathered data on the numbers of beached oiled birds with the goal of using the data to generate an estimate of the total number of impacted birds. Ideally, this estimate would be used to apply for compensation under the Oil Pollution Act of 1990.

\section{Research Study Site}

The sunken S.S. Jacob Luckenbach lies just off the entrance of the San Francisco Bay, the converging point of the Gulf of the Farallones and Monterey Bay National Marine Sanctuaries. The Gulf of the Farallones National Marine sanctuary was dedicated by Congress in 1981 and incorporates 1,255 square miles of the San Francisco Bay region, located just north of the Monterey Bay National Marine Sanctuary. The Farallon Islands within the Gulf of the Farallones National Marine Sanctuary are a designated National Wildlife Refuge 
providing resting and breeding sites for 10,000 seals and sea lions and 400,000 seabirds, who are attracted each year to the nutrient rich waters created by upwellings along the sanctuary's 35 mile extended continental shelf. Other sanctuary inhabitants include the dungeness crab, California gray whale, humpback whale, blue whale, rockfish, and abalone. The Gulf of the Farallones National Marine Sanctuary supports the largest concentration of breeding seabirds within the continental United States (Monterey Bay Aquarium Foundation 1997).

The Monterey Bay National Marine Sanctuary, dedicated by Congress in 1992, is presently the largest national marine sanctuary, spanning 5,300 square miles between San Francisco and San Luis Obispo counties, an area greater than either Yosemite or Yellowstone National Parks. The sanctuary includes one of the largest and deepest submarine canyons off North America's west coast, which, at its deepest point, 10,663 feet, is twice the depth of the Grand Canyon (Monterey Bay Aquarium Foundation 1997). Remarkably, the Monterey Bay National Marine Sanctuary not only provides breeding, feeding, and migration areas for over 26 species of marine mammals, 94 species of birds, and 345 species of fish, but is also a significant cultural site of 1,276 reported shipwrecks and 718 coastal prehistoric sites (Monterey Bay Aquarium Foundation 1997).

This methods section describes the S.S. Jacob Luckenbach beach search methods first and then the design and analysis methods for this thesis. 


\section{S.S. Jacob Luckenbach Beach Search Effort}

The raw beach search effort survey data provided by the Department of Fish and Game was collected between December 17, 2002 and January 1, 2003 along the central California coastline between the Sonoma and Monterey counties.

Using Beach Search Effort Logs (survey logs), data were collected by searchers from non-profit organizations, government agencies, and private business. Searchers were verbally instructed by the Department of Fish and Game to survey stretches of beach along the central California coastline looking for, collecting, and recording the presence of, oiled birds, dead or alive (Table 1). Although the survey log formats varied, in general, searchers were required to record the following data: oil spill name, date of search, names of searchers, beach segment name, total distance searched per beach segment using geographic positioning system (GPS) coordinates, start and end time of beach segment searched, search method, e.g., foot, point, or vehicle scan, of each beach segment, and the number of oiled birds observed per beach segment (appendix A).

Table 1: S.S. Jacob Luckenbach Beach Search Effort Field Methods

\begin{tabular}{|c|l|l|l|}
\hline Search Method & \multicolumn{1}{|c|}{ Definition } & Field Equipment & $\begin{array}{c}\text { Procedure for } \\
\text { located oiled birds, } \\
\text { dead and alive }\end{array}$ \\
\hline FOOT SEARCH & $\begin{array}{l}\text { For two searchers with a } \\
\text { vehicle: one searcher } \\
\text { walks along the back } \\
\text { of the beach and the } \\
\text { second searcher walks }\end{array}$ & $\begin{array}{l}\text { GPS device, search effort } \\
\text { log, sometimes on rain- } \\
\text { proof paper, pillowcases } \\
\text { or nets for capturing live } \\
\text { birds, waterproof bags, }\end{array}$ & $\begin{array}{l}\text { Unoiled dead birds } \\
\text { are left on the beach } \\
\text { and noted in the } \\
\text { search effort log. }\end{array}$ \\
\hline
\end{tabular}




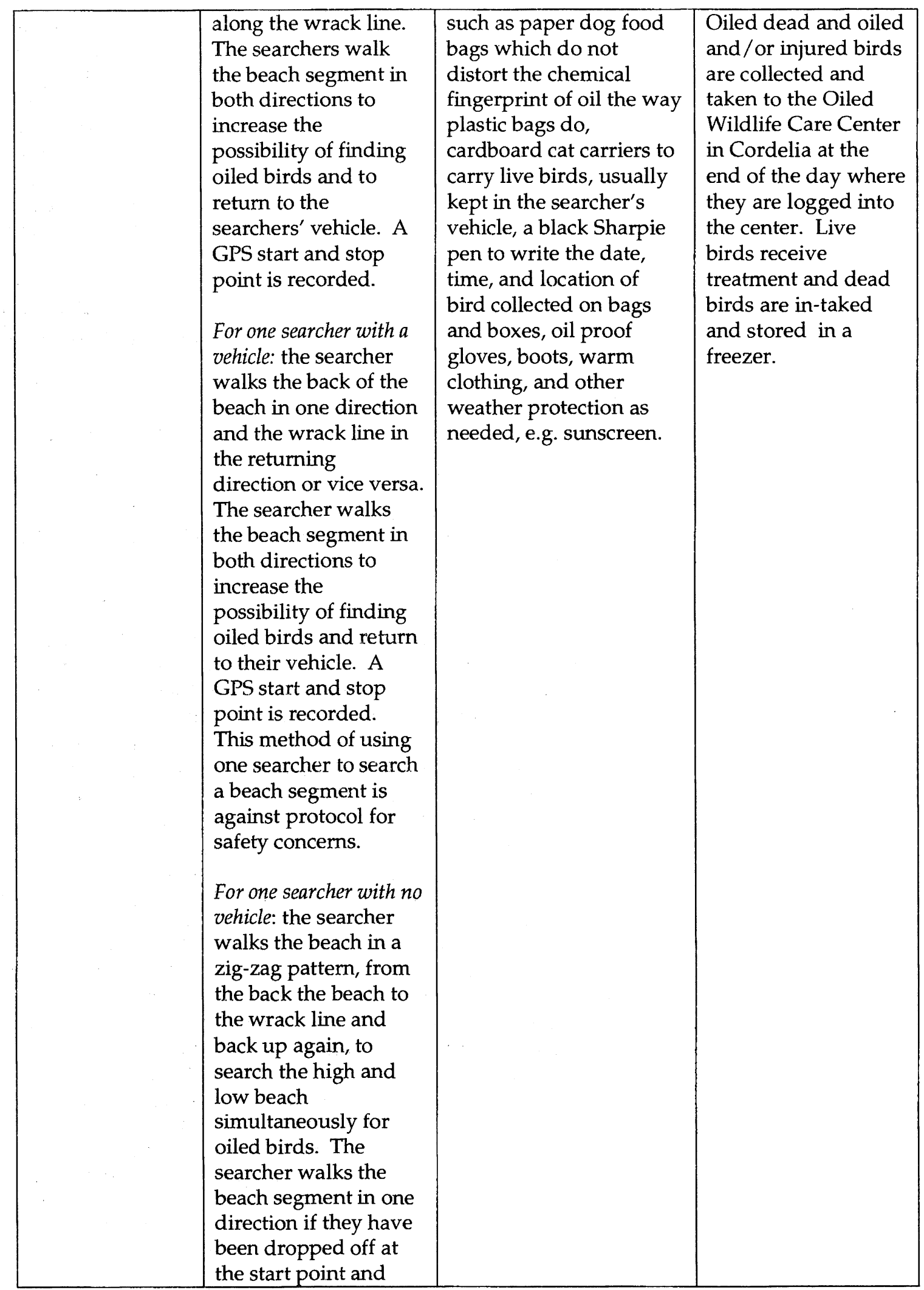




\begin{tabular}{|c|c|c|c|}
\hline & $\begin{array}{l}\text { will be picked up at } \\
\text { the end point. A GPS } \\
\text { start and stop point is } \\
\text { recorded. This } \\
\text { method of using one } \\
\text { searcher to search a } \\
\text { beach segment is } \\
\text { against protocol for } \\
\text { safety concerns. } \\
\text { "Rate" in foot } \\
\text { searches refers to time } \\
\text { spent on the beach, as } \\
\text { time spent surveying } \\
\text { beach segments } \\
\text { increases the chance } \\
\text { of finding oiled birds. }\end{array}$ & & \\
\hline Search Method & Definition & Field Equipment & $\begin{array}{l}\text { Procedure for } \\
\text { located oiled birds, } \\
\text { dead and alive }\end{array}$ \\
\hline $\begin{array}{l}\text { POINT SCAN } \\
\text { SEARCH }\end{array}$ & $\begin{array}{l}\text { The searcher records a } \\
\text { GPS starting point } \\
\text { and point scans the } \\
\text { length of a beach } \\
\text { segment by standing } \\
\text { at one point of the } \\
\text { beach segment and } \\
\text { surveying the } \\
\text { segment for oiled } \\
\text { birds using } \\
\text { binoculars. } \\
\text { Searchers who did not } \\
\text { have time to conduct } \\
\text { foot searches of beach } \\
\text { segments developed } \\
\text { this method. } \\
\text { "Rate" in point scan } \\
\text { searches refers to time } \\
\text { scanning the beach } \\
\text { segment, as time spent } \\
\text { on the beach increases } \\
\text { the chance of finding } \\
\text { oiled birds. }\end{array}$ & $\begin{array}{l}\text { GPS device, search effort } \\
\text { log, sometimes on rain- } \\
\text { proof paper, pillowcases } \\
\text { or nets for capturing live } \\
\text { birds, waterproof bags, } \\
\text { such as paper dog food } \\
\text { bags which do not } \\
\text { distort the chemical } \\
\text { fingerprint of oil the way } \\
\text { plastic bags do, } \\
\text { cardboard cat carriers to } \\
\text { carry live birds, usually } \\
\text { kept in the searcher's } \\
\text { vehicle, a black Sharpie } \\
\text { pen to write the date, } \\
\text { time, and location of } \\
\text { bird collected on bags } \\
\text { and boxes, oil proof } \\
\text { gloves, boots, warm } \\
\text { clothing, and other } \\
\text { weather protection as } \\
\text { needed, e.g. sunscreen. }\end{array}$ & $\begin{array}{l}\text { Unoiled dead birds } \\
\text { are left on the beach } \\
\text { and noted in the } \\
\text { search effort log. } \\
\text { Oiled dead and oiled } \\
\text { and/or injured birds } \\
\text { are collected and } \\
\text { taken to the Oiled } \\
\text { Wildlife Care Center } \\
\text { in Cordelia at the } \\
\text { end of the day where } \\
\text { they are logged into } \\
\text { the center. Live } \\
\text { birds receive } \\
\text { treatment and dead } \\
\text { birds are in-taked } \\
\text { and stored in a } \\
\text { freezer. }\end{array}$ \\
\hline
\end{tabular}




\begin{tabular}{|c|c|c|c|}
\hline Search Method & Definition & Field Equipment & $\begin{array}{l}\text { Procedure for } \\
\text { located oiled birds, } \\
\text { dead and alive }\end{array}$ \\
\hline $\begin{array}{l}\text { VEHICLE } \\
\text { SEARCH }\end{array}$ & $\begin{array}{l}\text { The searcher drives } \\
\text { the length of the beach } \\
\text { segment in one } \\
\text { direction surveying } \\
\text { for oiled birds. A GPS } \\
\text { start and stop point is } \\
\text { recorded. } \\
\text { Vehicles require } \\
\text { broad, flat, open } \\
\text { beaches with fine sand } \\
\text { to conduct searches. } \\
\text { "Rate" in vehicle } \\
\text { searches refers to the } \\
\text { rate of the vehicle's } \\
\text { speed traveled along } \\
\text { the beach segment, i.e. } \\
\text { miles per hour. }\end{array}$ & $\begin{array}{l}\text { GPS device, search effort } \\
\text { log, sometimes on rain- } \\
\text { proof paper, pillowcases } \\
\text { or nets for capturing live } \\
\text { birds, waterproof bags, } \\
\text { such as paper dog food } \\
\text { bags which do not } \\
\text { distort the chemical } \\
\text { fingerprint of oil the way } \\
\text { plastic bags do, } \\
\text { cardboard cat carriers to } \\
\text { carry live birds, usually } \\
\text { kept in the searcher's } \\
\text { vehicle, a black Sharpie } \\
\text { pen to write the date, } \\
\text { time, and location of } \\
\text { bird collected on bags } \\
\text { and boxes, oil proof } \\
\text { gloves, boots, warm } \\
\text { clothing, and other } \\
\text { weather protection as } \\
\text { needed, e.g. sunscreen. }\end{array}$ & $\begin{array}{l}\text { Unoiled dead birds } \\
\text { are left on the beach } \\
\text { and noted in the } \\
\text { search effort log. } \\
\text { Oiled dead and oiled } \\
\text { and/or injured birds } \\
\text { are collected and } \\
\text { taken to the Oiled } \\
\text { Wildlife Care Center } \\
\text { in Cordelia at the } \\
\text { end of the day where } \\
\text { they are logged into } \\
\text { the center. Live } \\
\text { birds receive } \\
\text { treatment and dead } \\
\text { birds are in-taked } \\
\text { and stored in a } \\
\text { freezer. }\end{array}$ \\
\hline Search Method & Definition & Field Equipment & $\begin{array}{c}\text { Procedure for } \\
\text { located oiled birds, } \\
\text { dead and alive }\end{array}$ \\
\hline $\begin{array}{l}\text { COMBO } \\
\text { FOOT/POINT } \\
\text { SCAN SEARCH }\end{array}$ & $\begin{array}{l}\text { Searcher conducts a } \\
\text { combination foot and } \\
\text { point scan survey of } \\
\text { the beach segment. } \\
\text { Searchers who did not } \\
\text { have time to conduct } \\
\text { foot searches of beach }\end{array}$ & $\begin{array}{l}\text { GPS device, search effort } \\
\text { log, sometimes on rain- } \\
\text { proof paper, pillowcases } \\
\text { or nets for capturing live } \\
\text { birds, waterproof bags, } \\
\text { such as paper dog food } \\
\text { bags which do not } \\
\text { distort the chemical }\end{array}$ & $\begin{array}{l}\text { Unoiled dead birds } \\
\text { are left on the beach } \\
\text { and noted in the } \\
\text { search effort log. } \\
\text { Oiled dead and oiled } \\
\text { and/or injured birds } \\
\text { are collected and }\end{array}$ \\
\hline
\end{tabular}




\begin{tabular}{|c|c|c|c|}
\hline & $\begin{array}{l}\text { segments developed } \\
\text { this method. }\end{array}$ & $\begin{array}{l}\text { fingerprint of oil the way } \\
\text { plastic bags do, } \\
\text { cardboard cat carriers to } \\
\text { carry live birds, usually } \\
\text { kept in the searcher's } \\
\text { vehicle, a black Sharpie } \\
\text { pen to write the date, } \\
\text { time, and location of } \\
\text { bird collected on bags } \\
\text { and boxes, oil proof } \\
\text { gloves, boots, warm } \\
\text { clothing, and other } \\
\text { weather protection as } \\
\text { needed, e.g. sunscreen. }\end{array}$ & $\begin{array}{l}\text { taken to the Oiled } \\
\text { Wildlife Care Center } \\
\text { in Cordelia at the } \\
\text { end of the day where } \\
\text { they are logged into } \\
\text { the center. Live } \\
\text { birds receive } \\
\text { treatment and dead } \\
\text { birds are in-taked } \\
\text { and stored in a } \\
\text { freezer. }\end{array}$ \\
\hline Search Method & Definition & Field Equipment & $\begin{array}{l}\text { Procedure for } \\
\text { located oiled birds, } \\
\text { dead and alive }\end{array}$ \\
\hline $\begin{array}{l}\text { COMBO } \\
\text { FOOT/VEHICLE } \\
\text { SEARCH }\end{array}$ & $\begin{array}{l}\text { Searcher conducts a } \\
\text { combination foot and } \\
\text { vehicle survey of the } \\
\text { beach segment. } \\
\text { Foot searches are used } \\
\text { when a vehicle cannot } \\
\text { access a beach } \\
\text { segment because it is } \\
\text { prohibited or } \\
\text { impossible, e.g. cliff or } \\
\text { stairs. } \\
\text { Vehicles require } \\
\text { broad, flat, open } \\
\text { beaches with fine sand } \\
\text { to conduct searches. }\end{array}$ & $\begin{array}{l}\text { GPS device, search effort } \\
\text { log, sometimes on rain- } \\
\text { proof paper, pillowcases } \\
\text { or nets for capturing live } \\
\text { birds, waterproof bags, } \\
\text { such as paper dog food } \\
\text { bags which do not } \\
\text { distort the chemical } \\
\text { fingerprint of oil the way } \\
\text { plastic bags do, } \\
\text { cardboard cat carriers to } \\
\text { carry live birds, usually } \\
\text { kept in the searcher's } \\
\text { vehicle, a black Sharpie } \\
\text { pen to write the date, } \\
\text { time, and location of } \\
\text { bird collected on bags } \\
\text { and boxes, oil proof } \\
\text { gloves, boots, warm } \\
\text { clothing, and other } \\
\text { weather protection as } \\
\text { needed, e.g. sunscreen. }\end{array}$ & $\begin{array}{l}\text { Unoiled dead birds } \\
\text { are left on the beach } \\
\text { and noted in the } \\
\text { search effort log. } \\
\text { Oiled dead and oiled } \\
\text { and/or injured birds } \\
\text { are collected and } \\
\text { taken to the Oiled } \\
\text { Wildlife Care Center } \\
\text { in Cordelia at the } \\
\text { end of the day where } \\
\text { they are logged into } \\
\text { the center. Live } \\
\text { birds receive } \\
\text { treatment and dead } \\
\text { birds are in-taked } \\
\text { and stored in a } \\
\text { freezer. }\end{array}$ \\
\hline
\end{tabular}




\section{Thesis Research Design and Data Analysis}

The purpose of this thesis is to address the following three research objectives:

First, what can be inferred about the rate of oiled birds from the S.S. Jacob Luckenbach beach search effort data? Do the data meet the goals of the beach search effort to estimate the total number of birds impacted by the S.S. Jacob

\section{Luckenbach?}

Second, according to the literature, what are the essential components of a reliable monitoring program designed to produce quantitative data?

Third, how can the S.S. Jacob Luckenbach beach search effort be changed to be a reliable program that meets the criteria developed for research question \#2?

To address the first research question, this thesis examined whether the search data could be used to estimate the total number of birds impacted by the S.S. Jacob Luckenbach. And, if such an estimate could not be developed, what could the data say. The data were analyzed for quality and then the actual number of birds impacted by oiling was correlated with searcher distance, time, and rate per beach segment. Next, $t$-Tests were used to analyze foot and combination foot/point scan search methods (methods for which there were enough data to conduct a statistical analysis).

The raw survey data were first prepared for analysis using only entirely complete beach segment entries from each Beach Search Effort Log. Log numbers were assigned to organize the surveys in descending order by date, 
starting with January 1, 2003, and ending with December 17, 2002, then, with the assistance of the U.S. Geological Survey, converted the GPS coordinates into meters to determine the length of each beach segment searched. Finally, the beach segment data was grouped by search method and organized them in ascending order by the number of birds found per search method. The summary data used for analysis included the survey log number, segment name, search method, distance searched in meters, time in minutes, number of birds observed, rate, birds per distance searched, birds present or absent, birds per time searched, and birds per distance per time (Appendix B).

Search methods were analyzed by four search method categories: foot, point, vehicle, and combination foot/point. Descriptive statistics were developed for each search method, which included its mean, standard error, median, mode, and standard deviation of each method's distance, time, number of birds, rate, birds/distance, birds/time, and birds/distance/time.

For two search methods, foot and combination foot/point searches, $t$-Test analyses were conducted to determine if there was a significance difference in search rate, time, or distance between when oiled birds were found and not found.

To address the second research question, essential components for a successful monitoring program were identified based on literature reviews of pre-existing 
monitoring programs. Components were compiled into a table for comparison to the S.S. Jacob Luckenbach beach search effort.

Based on the analysis for the two research questions, recommendations for how the S.S. Jacob Luckenbach beach search effort can be improved are made.

\section{Research Assumptions and Limitations}

The S.S. Jacob Luckenbach beach search effort research analysis is based on several assumptions:

Assumption 1: Because it is unknown when releases of oil occurred from the S.S. Jacob Luckenbach and no one specific search method type was any more correlated with a release of oil, different search method types occurred randomly and consistently so that it did not create a bias with respect to oiling, i.e., each different search method occurred at the same time, e.g., the same day.

Assumption 2: During the winter season when the greatest numbers of marine birds migrate toward the Farallon islands to forage in the open ocean surrounding the islands before congregating there to nest and rear their young in the spring and summer months, especially the Common Murre, the number and species of bird present in the affected area is about the same on any particular day. 
Assumption 3: On days when birds were found, if no entry was made in the Beach Search Effort Log column marked "Birds Collected," no birds were found along that beach segment.

Limitations in the data collected from the S.S. Jacob Luckenbach beach search effort affected the quantity and quality of data analyzed for this research:

Limitation 1: Inconsistent survey logs were utilized in the data collection effort. Different survey forms requested different kinds of beached bird data. Limitation 2: Data were entered illegibly in the survey logs.

Limitation 3: Data were entered incompletely, inaccurately, or inconsistently with the Beach Search Effort Log entry requirement. 


\section{RESULTS}

What can be inferred about the rate of oiled birds from the S.S. Jacob Luckenbach beach search effort data? Do the data meet the goals of the beach search effort to estimate the total number of birds impacted by the S.S. Jacob Luckenbach?

This analysis revealed that the available data were not adequate to create a quantifiable index to determine the total number of birds impacted by oil from the S.S. Jacob Luckenbach for these reasons:

1) Standardized field search methods were not established. For example, what started out as a foot search evolved into a point scan if a searcher ran out of time to complete the search, and therefore, search methods could not be compared. Additionally, the area covered in each beach segment could not be quantified.

2) There were not enough data for each type of search method to be statistically analyzed.

3) A searcher efficiency rate was not established. Regardless of search method, the area searched in each beach segment and the efficiency of the search needs to be identified to estimate the total number of impacted birds. For example, if one beach segment, representing ten percent of the total beach, is searched, and twenty impacted birds are in the beach 
segment, and searchers find only ten, or half, of those birds, then the searcher efficiency calculation is $10 \times 10 \times 2$. This standard had not been established to calculate the number of birds missed by searchers and must be factored into any estimate of the actual number of birds impacted by oiling.

4) Some data were not adequately recorded and there was no standard quality control procedure.

Although a quantifiable index could not be determined, enough data were collected from two methods, foot searches and combination foot/point scan searches, to allow t-Test comparisons between searches when birds were found versus not found for rate, time, and distance.

$\mathrm{t}$-Test analyses of the foot search method (Table 2) show that on days birds were found, searchers spent significantly more time searching and traveled significantly farther than on days when oiled birds were not found. Mean rate of travel had no effect on whether birds were found or not. 
Table 2: Foot Search Method Results Comparing Data When Birds Found and Not Found

\begin{tabular}{|c|c|c|c|c|c|c|}
\hline & \multicolumn{2}{|c|}{ Birds Found } & \multicolumn{2}{|c|}{ Birds Not Found } & \multirow[b]{2}{*}{$\begin{array}{l}P(T<=) \\
\text { two tail }\end{array}$} & \multirow[b]{2}{*}{$\begin{array}{c}\text { Level of } \\
\text { Significance }\end{array}$} \\
\hline & $\mathbf{N}$ & Mean & $\mathbf{N}$ & Mean & & \\
\hline $\begin{array}{c}\text { Mean } \\
\text { Distances } \\
\text { (meters) }\end{array}$ & 25 & 2073.04 & 31 & 1146.19 & 0.03499939 & Significant \\
\hline $\begin{array}{c}\text { Mean } \\
\text { Times } \\
\text { (minutes) }\end{array}$ & 25 & 109.88 & 31 & 30.29 & $8.5981 \mathrm{E}-05$ & $\begin{array}{c}\text { Very } \\
\text { significant }\end{array}$ \\
\hline $\begin{array}{c}\text { Mean } \\
\text { Rates of } \\
\text { Travel }\end{array}$ & 25 & 24.84 & 31 & 49.76 & 0.05967602 & $\begin{array}{c}\text { Not } \\
\text { significant }\end{array}$ \\
\hline
\end{tabular}

Table 3 shows that, for the combined foot/point scan search method, no parameter - time searching, distance covered, and rate of search - had an effect on whether birds were found or not. 
Table 3: Combination Foot/Point Scan Search Method Results Comparing Data When Birds Found and Not Found

\begin{tabular}{|c|c|c|c|c|c|c|}
\hline \multicolumn{5}{c}{} & \multicolumn{1}{c}{ Birds Found } & \multicolumn{1}{c}{ Birds Not Found } \\
\multicolumn{1}{c}{ N } & Mean & \multicolumn{2}{c}{ Mean } & \multicolumn{1}{c}{$\begin{array}{c}\text { P (T<=) } \\
\text { two tail }\end{array}$} & $\begin{array}{c}\text { Level of } \\
\text { Significance }\end{array}$ \\
\hline $\begin{array}{c}\text { Mean } \\
\text { Distances } \\
\text { (meters) }\end{array}$ & 10 & 1664.00 & 16 & 1158.18 & 0.57838642 & $\begin{array}{c}\text { Not } \\
\text { Significant }\end{array}$ \\
\hline $\begin{array}{c}\text { Mean } \\
\text { Times } \\
\text { (minutes) }\end{array}$ & 10 & 63.4 & 16 & 32.37 & 0.17054228 & $\begin{array}{c}\text { Not } \\
\text { significant }\end{array}$ \\
\hline $\begin{array}{c}\text { Mean } \\
\text { Rates of } \\
\text { Travel }\end{array}$ & 10 & 246.72 & 16 & 48.42 & 0.40982774 & $\begin{array}{c}\text { Not } \\
\text { significant }\end{array}$ \\
\hline
\end{tabular}

Table 4 provides a qualitative evaluation, percent of cases in which birds were found, of the effectiveness of each search method for locating oiled birds. An assumption of this analysis is that the same number of oiled birds can be found on any random day. Given this assumption, Table 4 shows that foot searches are the most efficient search method as it yielded the highest percent, $45 \%$, of cases in which birds were found. Point scan searches yielded the lowest percentages of when birds were found. Although vehicle searches may have potential, too few data were collected to confirm whether this search method is effective. 
Table 4: Percent of Cases in Which Birds Were Found by Search Method

\begin{tabular}{|c|c|c|l|}
\hline $\begin{array}{c}\text { Search } \\
\text { Method }\end{array}$ & $\begin{array}{c}\text { Cases Birds } \\
\text { Found/ } \\
\text { Total Cases }\end{array}$ & $\begin{array}{c}\text { Percent Cases } \\
\text { Found }\end{array}$ & \multicolumn{1}{c|}{ Results } \\
\hline $\begin{array}{c}\text { Foot } \\
\text { Scan }\end{array}$ & $25 / 56$ & $45 \%$ & $\begin{array}{l}\text { Foot searches seem to be a } \\
\text { good survey method. }\end{array}$ \\
\hline $\begin{array}{c}\text { Point Scan } \\
\text { Vehicle }\end{array}$ & $10 / 26$ & $39 \%$ & $\begin{array}{l}\text { Adding point scan searches } \\
\text { to foot searches seem to } \\
\text { dilute the foot search } \\
\text { survey data. }\end{array}$ \\
\hline Foot/Vehicle & $2 / 14$ & $14 \%$ & $\begin{array}{l}\text { Point scan searches seem } \\
\text { to yield poor data results. }\end{array}$ \\
\hline & $5 / 6$ & $50 \%$ & $\begin{array}{l}\text { Vehicle searches seem to } \\
\text { have potential; too few } \\
\text { data to know. }\end{array}$ \\
\hline & & $83 \%$ & $\begin{array}{l}\text { Combination foot/vehicle } \\
\text { searches seem to have } \\
\text { potential; too few data to } \\
\text { know. }\end{array}$ \\
\hline
\end{tabular}

Table 5 provides the program components from the literature for a successful monitoring program. To develop an effective monitoring program that is efficient, well planned, well documented, and statistically robust, program design, implementation, evaluation, and barriers to success must be identified. The four components of a reliable monitoring program, the design, 
implementation, evaluation, and barrier considerations (Vora 1997, Griffith 1998, Wells 1999, EPA 1996, Ringold et al. 1999, Natural Resources Defense Council 1999, Rees and Pond 1995, Nelson 1993, Krogh and Koop 1996, Agnew 1997, Lee and Pritchard 1996, Ogden et al. 1994, Epstein 1995, Malone and Nemazie 1996, Armstrong et al. 1996, Gilfillan et al. 1999, Gulf of the Farallones National Marine Sanctuary n.d.), are listed in Table 5.

For each of these components, Table 5 lists the respective elements, justifications, and examples from the literature. These components and elements provide a model for an ideal monitoring program. The S.S. Jacob Luckenbach beach search effort is compared to this model in Table 5 .

Table 5: Essential Monitoring Program Components

\begin{tabular}{|c|c|c|c|c|}
\hline $\begin{array}{l}\text { Programmatic } \\
\text { Consideration }\end{array}$ & Element & Example & Citation & $\begin{array}{c}\text { S.S. Jacob } \\
\text { Luckenbach Oil } \\
\text { Spill Response }\end{array}$ \\
\hline $\begin{array}{l}\text { 1. Design } \\
\text { Considerations } \\
\text { Programmatic } \\
\text { design must clearly } \\
\text { identify why the } \\
\text { program exists and } \\
\text { what value it adds } \\
\text { to policy } \\
\text { considerations and } \\
\text { research efforts in } \\
\text { this field. }\end{array}$ & $\begin{array}{l}\text { Purpose, goals, } \\
\text { and objectives } \\
\text { The purpose, } \\
\text { goals, and } \\
\text { objectives } \\
\text { identify why a } \\
\text { monitoring } \\
\text { program exists, } \\
\text { what is plans to } \\
\text { achieve, and } \\
\text { how, i.e. is it a } \\
\text { tool for agency } \\
\text { managers to } \\
\text { identify priorities } \\
\text { in research, } \\
\text { regulations, and } \\
\text { new } \\
\text { developments or } \\
\text { whether it serves } \\
\text { as an early }\end{array}$ & $\begin{array}{l}\text { EPA's } \\
\text { Environmental } \\
\text { Monitoring and } \\
\text { Assessment } \\
\text { Program }\end{array}$ & $\begin{array}{l}\text { Vora 1997; } \\
\text { Griffith 1998; } \\
\text { Wells 1999; } \\
\text { EPA 1996; } \\
\text { Ringold et.al } \\
\text { 1999; Natural } \\
\text { Resources } \\
\text { Defense } \\
\text { Council } 1999\end{array}$ & $\begin{array}{l}\text { Purpose: } \\
\text { Restore seabirds } \\
\text { to pre- } \\
\text { Luckenbach spill } \\
\text { levels and } \\
\text { provide } \\
\text { compensatory } \\
\text { restoration to the } \\
\text { public for interim } \\
\text { losses. } \\
\text { Goal: } \\
\text { Develop a } \\
\text { natural resource } \\
\text { damage } \\
\text { assessment as } \\
\text { part of the } \\
\text { natural resource }\end{array}$ \\
\hline
\end{tabular}




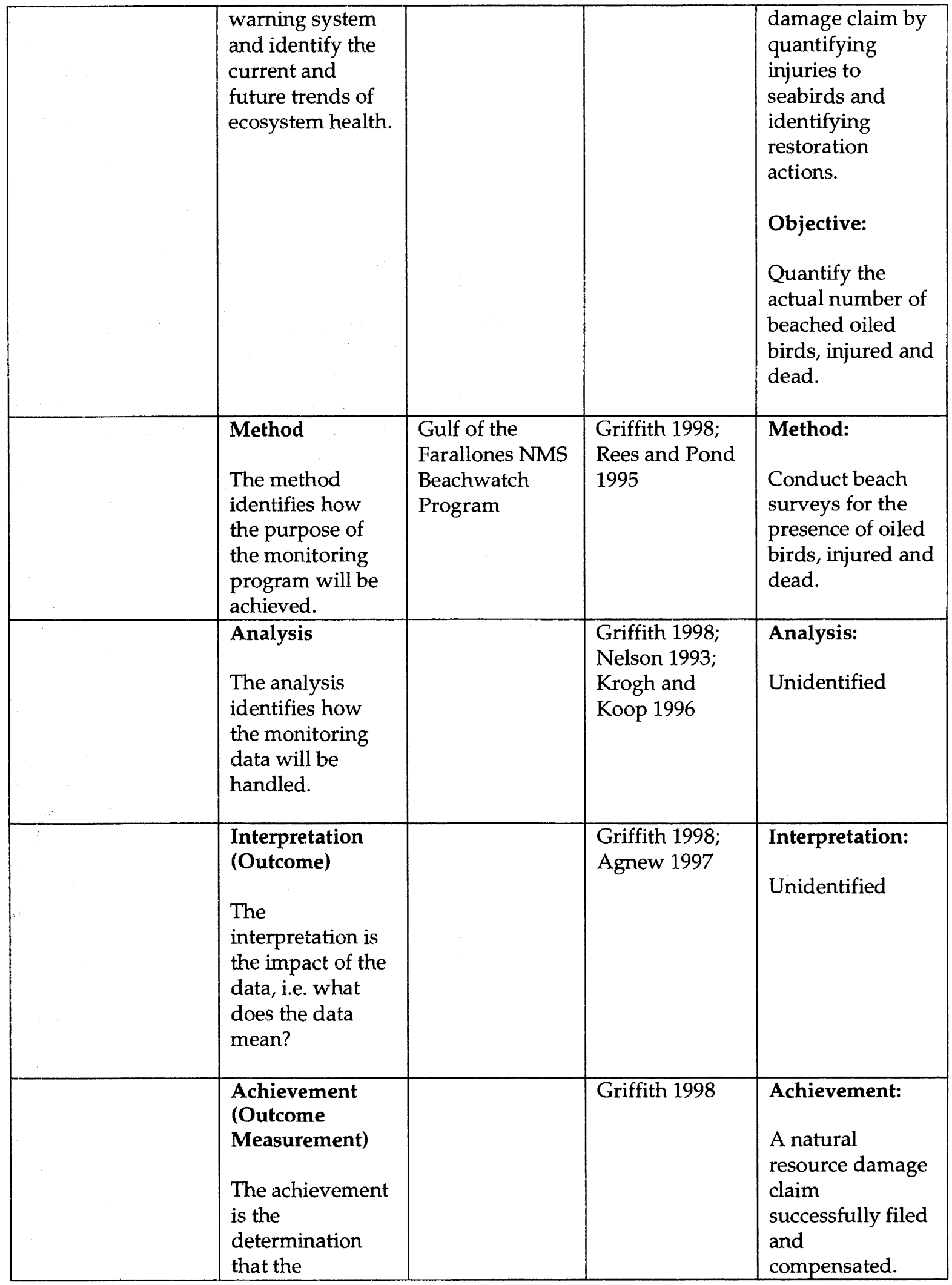




\begin{tabular}{|c|c|c|c|c|}
\hline & $\begin{array}{l}\text { monitoring } \\
\text { program's } \\
\text { purpose has been } \\
\text { met, i.e. when } \\
\text { will the goal be } \\
\text { achieved? }\end{array}$ & & & \\
\hline $\begin{array}{l}\text { Programmatic } \\
\text { Consideration }\end{array}$ & Element & Example & Citation & $\begin{array}{c}\text { S.S. Jacob } \\
\text { Luckenbach Oil } \\
\text { Spill Response }\end{array}$ \\
\hline $\begin{array}{l}\text { 2. Implementation } \\
\text { Considerations } \\
\text { Programmatic } \\
\text { implementation } \\
\text { must clarify how } \\
\text { the monitoring } \\
\text { program exists, i.e. } \\
\text { how it is carried } \\
\text { out }\end{array}$ & $\begin{array}{l}\text { Data Sampling } \\
\text { and Analysis } \\
\text { Data sampling } \\
\text { and analysis } \\
\text { establish the } \\
\text { power, or } \\
\text { effectiveness to } \\
\text { produce desired } \\
\text { results of the } \\
\text { monitoring } \\
\text { program's efforts. } \\
\text { Sampling design } \\
\text { should } \\
\text { incorporate the } \\
\text { appropriate } \\
\text { number of } \\
\text { samples within a } \\
\text { given site to yield } \\
\text { effective results; } \\
\text { use fixed versus } \\
\text { variable data } \\
\text { along a transect; } \\
\text { identify the type } \\
\text { of field } \\
\text { equipment used, } \\
\text { and know when } \\
\text { and how long to } \\
\text { conduct } \\
\text { sampling at a } \\
\text { site. } \\
\text { Data collection } \\
\text { efforts should be } \\
\text { long term to } \\
\text { make } \\
\text { assessments } \\
\text { about human }\end{array}$ & $\begin{array}{l}\text { Gulf of the } \\
\text { Farallones NMS } \\
\text { Lee and } \\
\text { Pritchard's } \\
\text { Before and After } \\
\text { Control Impact } \\
\text { Study }\end{array}$ & $\begin{array}{l}\text { Nelson 1993; } \\
\text { Krogh and } \\
\text { Koop 1996; Lee } \\
\text { and Pritchard } \\
\text { 1996; Ogden et } \\
\text { al. 1994 }\end{array}$ & $\begin{array}{l}\text { Data Sampling } \\
\text { and Analysis: } \\
\text { Data sampling } \\
\text { incorporated five } \\
\text { beach survey } \\
\text { methodologies } \\
\text { 1) Foot Scan } \\
\text { 2) Point Scan } \\
\text { 3) Vehicle Scan } \\
\text { 4) Foot/ } \\
\text { Vehicle } \\
\text { 5) Foot/ } \\
\text { Point } \\
\text { Scan }\end{array}$ \\
\hline
\end{tabular}




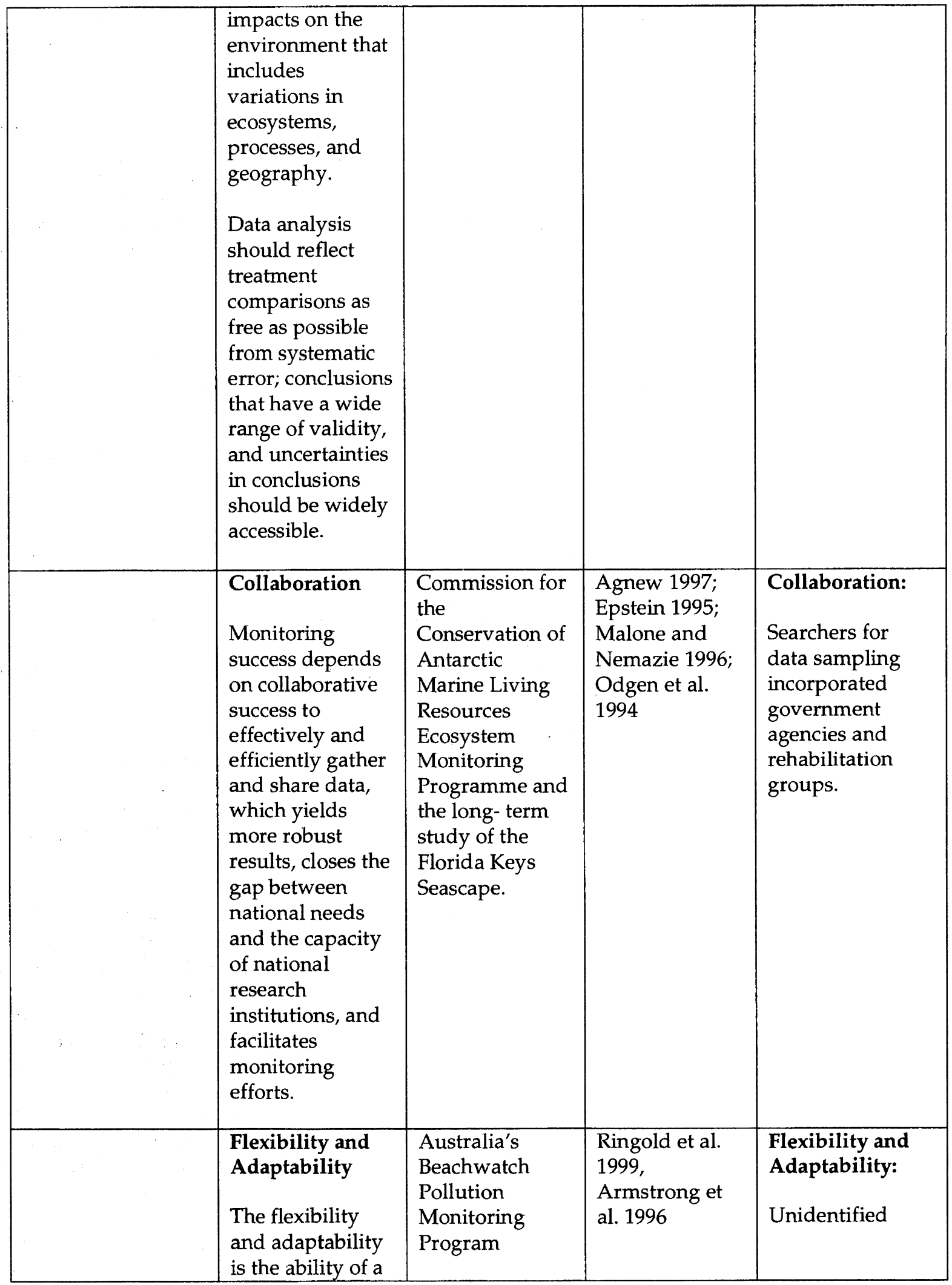




\begin{tabular}{|c|c|c|c|c|}
\hline & $\begin{array}{l}\text { program to } \\
\text { change priorities } \\
\text { to recognize } \\
\text { changed } \\
\text { circumstances. }\end{array}$ & & & \\
\hline & $\begin{array}{l}\text { Training } \\
\text { Training, both } \\
\text { initial and } \\
\text { refresher courses, } \\
\text { reinforces the } \\
\text { monitoring } \\
\text { program's field } \\
\text { protocols for } \\
\text { volunteer } \\
\text { surveyors to } \\
\text { ensure proper } \\
\text { data collection in } \\
\text { an effort to yield } \\
\text { a data set as free } \\
\text { from error as } \\
\text { possible. }\end{array}$ & $\begin{array}{l}\text { Gulf of the } \\
\text { Farallones NMS } \\
\text { Beach Watch } \\
\text { Program }\end{array}$ & & $\begin{array}{l}\text { Training: } \\
\text { Informal training } \\
\text { on survey field } \\
\text { equipment and } \\
\text { methodologies }\end{array}$ \\
\hline $\begin{array}{l}\text { Programmatic } \\
\text { Consideration }\end{array}$ & Element & Example & Citation & $\begin{array}{c}\text { S.S. Jacob } \\
\text { Luckenbach Oil } \\
\text { Spill Response }\end{array}$ \\
\hline $\begin{array}{l}\text { 3. Evaluation } \\
\text { Considerations } \\
\text { Programmatic } \\
\text { evaluation must } \\
\text { consider a } \\
\text { program's power, } \\
\text { or effectiveness to } \\
\text { produce desired } \\
\text { results, i.e. include } \\
\text { assessment criteria } \\
\text { to determine the } \\
\text { success of the } \\
\text { monitoring } \\
\text { program, whether } \\
\text { the goals and } \\
\text { objectives are being } \\
\text { met. }\end{array}$ & $\begin{array}{l}\text { Assessment } \\
\text { Criteria } \\
\text { The assessment } \\
\text { criteria evaluates } \\
\text { the coastal } \\
\text { monitoring } \\
\text { program's ability } \\
\text { detect the impact } \\
\text { of oiling on a } \\
\text { beach. } \\
\text { Assessment } \\
\text { strategies should } \\
\text { include the } \\
\text { highest number } \\
\text { of research sites } \\
\text { surveyed to take } \\
\text { into account data } \\
\text { variation; beach } \\
\text { sites researched } \\
\text { should be in } \\
\text { heavily oiled }\end{array}$ & $\begin{array}{l}\text { Three shoreline } \\
\text { assessment } \\
\text { studies used in } \\
\text { the aftermath of } \\
\text { the Exxon } \\
\text { Valdez spill: } \\
\text { 1) Exxon's } \\
\text { Shoreline } \\
\text { Ecology } \\
\text { Program } \\
\text { 2) Coastal } \\
\text { Habitat } \\
\text { Injury } \\
\text { Assessment } \\
\text { Program } \\
\text { conducted } \\
\text { for Exxon } \\
\text { 3) Biological } \\
\text { Monitoring }\end{array}$ & $\begin{array}{l}\text { Gilfillan et al. } \\
1999\end{array}$ & $\begin{array}{l}\text { Assessment } \\
\text { Criteria: } \\
\text { Unidentified }\end{array}$ \\
\hline
\end{tabular}




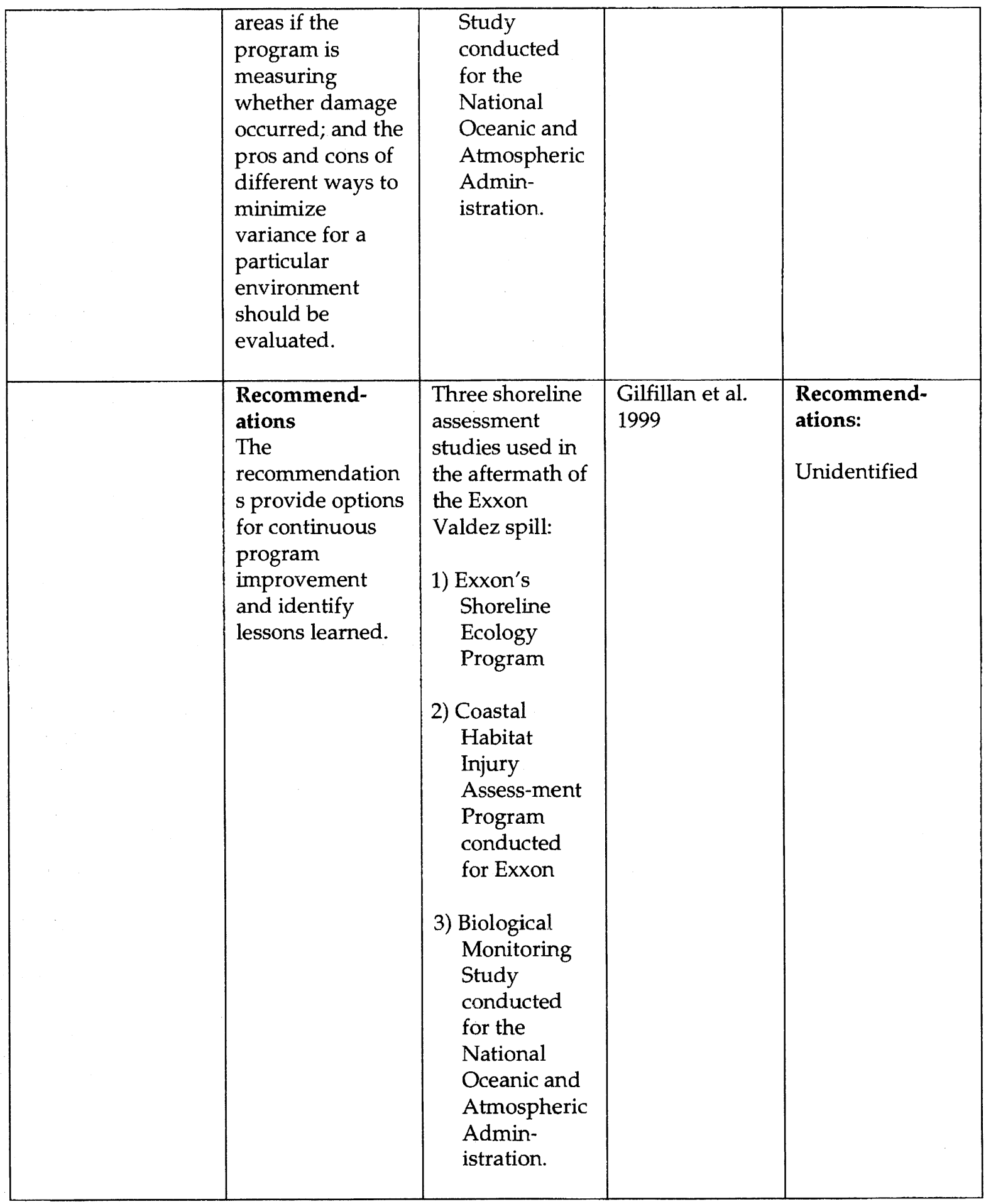




\begin{tabular}{|c|c|c|c|c|}
\hline $\begin{array}{l}\text { Programmatic } \\
\text { Consideration }\end{array}$ & Element & Example & Citation & $\begin{array}{c}\text { S.S. Jacob } \\
\text { Luckenbach Oil } \\
\text { Spill Response }\end{array}$ \\
\hline $\begin{array}{l}\text { 4. Barrier } \\
\text { Considerations } \\
\text { Programmatic } \\
\text { barriers must be } \\
\text { considered and } \\
\text { understood in an } \\
\text { effort to 1) conduct } \\
\text { continuous process } \\
\text { improvements and } \\
\text { 2) identify and } \\
\text { recommend policy } \\
\text { and budget } \\
\text { implications. }\end{array}$ & $\begin{array}{l}\text { Design } \\
\text { Design barriers } \\
\text { include the lack } \\
\text { of clear } \\
\text { objectives, } \\
\text { inconsistent, } \\
\text { changing, or non- } \\
\text { existent methods, } \\
\text { and the lack of } \\
\text { available } \\
\text { information to } \\
\text { provide effective } \\
\text { and relevant } \\
\text { ecological } \\
\text { indicators to } \\
\text { assess } \\
\text { environmental } \\
\text { quality. }\end{array}$ & & $\begin{array}{l}\text { Ringold et al. } \\
\text { 1999; Griffith } \\
1998\end{array}$ & $\begin{array}{l}\text { Design: } \\
\text { Inconsistent data } \\
\text { collection } \\
\text { methods; } \\
\text { informal } \\
\text { surveyor training } \\
\text { methods; } \\
\text { unidentified } \\
\text { study analysis, } \\
\text { interpretation, } \\
\text { flexibility and } \\
\text { adaptability, } \\
\text { assessment } \\
\text { criteria, and } \\
\text { recommend- } \\
\text { ations. }\end{array}$ \\
\hline & $\begin{array}{l}\text { Environmental } \\
\text { Environment-al } \\
\text { barriers includes } \\
\text { the inability to } \\
\text { discriminate } \\
\text { between natural } \\
\text { variation and } \\
\text { human induced } \\
\text { changes, since } \\
\text { natural processes } \\
\text { occur on a time } \\
\text { scale different } \\
\text { than research } \\
\text { funding cycles, } \\
\text { and choosing } \\
\text { study sites based } \\
\text { solely on } \\
\text { development or } \\
\text { access, for } \\
\text { example, which } \\
\text { does not } \\
\text { accurately reflect } \\
\text { changes to the } \\
\text { ecosystem as a } \\
\text { whole. }\end{array}$ & & $\begin{array}{l}\text { Odgen et al. } \\
1994\end{array}$ & $\begin{array}{l}\text { Environmental: } \\
\text { Limited beach } \\
\text { access for } \\
\text { surveyors and } \\
\text { low observation } \\
\text { rate due to } \\
\text { scavenging, re- } \\
\text { wash, burial, or } \\
\text { surveyor } \\
\text { efficiency of } \\
\text { beached oiled } \\
\text { birds. }\end{array}$ \\
\hline
\end{tabular}




\begin{tabular}{|l|l|l|l|l|}
\hline & $\begin{array}{l}\text { Institutional } \\
\text { Institutional } \\
\text { barriers include } \\
\text { changes in } \\
\text { government } \\
\text { priorities, } \\
\text { programmatic } \\
\text { and financial, } \\
\text { which restrict } \\
\text { studies to shorter } \\
\text { time frames } \\
\text { yielding only } \\
\text { short-term } \\
\text { results. }\end{array}$ & $\begin{array}{l}\text { Lee and } \\
\text { Pritchard 1996; } \\
\text { Epstein 1995 }\end{array}$ & $\begin{array}{l}\text { Institutional: } \\
\text { Lack of budget } \\
\text { and resources for } \\
\text { surveyor training } \\
\text { in protocols and } \\
\text { equipment. }\end{array}$ \\
\hline
\end{tabular}

The S.S. Jacob Luckenbach beach search effort followed the model by including a purpose, goal, objective, method, outcome measurement, data sampling technique, means for collaboration, and informal training. However, the beach search effort was missing an analysis tool, data outcome, demonstrated flexibility and adaptability, formal training, assessment criteria, recommendations, and unidentified design, environmental, and institutional barriers to success.

Finally, how can the S. S. Jacob Luckenbach beach search effort be changed to be a reliable program that meets the criteria developed for research question \#2?

After comparing the beach search effort field methods with the essential components of pre-existing monitoring programs, Table 6 outlines the methodological changes needed in the S.S. Jacob Luckenbach beach search effort to produce quantifiable data. 
Table 6: Methodological Changes Needed in the S.S. Jacob Luckenbach Beach Search Effort

\begin{tabular}{|l|l|}
\hline \multicolumn{1}{|c|}{ Existing Condition } & \multicolumn{1}{|c|}{ Methodological Change } \\
\hline Ineffective program design & $\begin{array}{l}\text { Establish, document, and re-affirm standardized } \\
\text { beach search protocols. }\end{array}$ \\
\hline Insufficient searcher training & $\begin{array}{l}\text { Train searchers consistently and often in established } \\
\text { field search methods, including accurate, consistent, } \\
\text { and complete data entry methods and proper use of } \\
\text { of field equipment, e.g. GPS hand-held devices. }\end{array}$ \\
\hline Unknown searcher efficiency rate & $\begin{array}{l}\text { Establish prior test to determine searcher } \\
\text { efficiency, such as placing a known number } \\
\text { of oiled bird carcasses along beach segments } \\
\text { and testing trained searchers to recover } \\
\text { the birds and estimating their error recovery } \\
\text { rate to apply to an actual search effort. }\end{array}$ \\
\hline
\end{tabular}




\section{DISCUSSION}

The overall goal of the S.S. Jacob Luckenbach beach search effort is to develop a quantitative index for estimating the total number of impacted birds.

Developing this estimate is hampered by problems with data quality and insufficient quantity.

Data quality problems began with the use of too many search methods. None of the search methods gave an estimate of the total amount of beach covered, i.e., total area searched. Also, the efficiency of all the methods is unknown. Tables 2, 3 , and 4 indicate that foot searches were the most likely to reveal oiled birds and the efficiency of these searches increased with the time spent and distance covered. Point scan searches were very inefficient and the location of oiled birds did not improve with increased effort (time and/or distance). This analysis indicates that foot searches should be used as a method to find oiled birds. Program designers must determine the amount of time or distance needed to maximize finding birds.

Data entries in the Beach Search Effort Logs were often inaccurate due to the improper use of GPS hand-held devices that led to incorrectly recorded coordinate data, i.e., searched beach segments often had corresponding coordinates that indicated searchers had surveyed beach segments on the open ocean (Appendix C). Several data entries in the Beach Search Effort Logs were 
also incomplete and illegible. Additionally, more than one version of a Beach Search Effort Log form was used by searchers in the field, which provided inconsistent results in the types of data collected. Therefore, data entries that were inaccurate, incomplete, illegible, or inconsistent between forms, could not be included in this research analysis, limiting the quantity of data for analysis.

However, there were enough data of adequate quality to conduct t-Test analyses of foot and combination foot/point scan search methods with respect to mean distances, times, and rates traveled by searchers only when birds were and were not observed.

The foot search field method revealed that the time searchers spent traveling each segment of beach by foot was a factor in observing the most birds, versus the distance traveled by searchers in each beach segment, and less important, the rate traveled by searchers in each beach segment. Therefore, the greater the time, approximately 100 minutes, and distance, approximately 2,070 meters, searchers spend searching beach segments by foot increases the opportunity more birds will be observed. This finding shows that greater effort produces better results, which is what is needed in a good search method. However, even the foot search method data are difficult to interpret because there was variability within the types of foot searches implemented in the field and out of three types used, only two of them were similar. Both one and two searchers with a vehicle walked the length of a beach segment in a straight line in one direction and back in the other, 
whereas one searcher with no vehicle walked a beach segment in a zig-zag pattern in one direction and back in the other.

Conversely, the statistical significance of the combination foot/point scan search method revealed that this search method is less superior to searchers traveling by foot alone. In all three comparisons of mean time, distance, and rate when birds were and were not observed, revealed that combining foot searches with a point scan search does not increase the chance that birds are observed in a beach segment. Combining a point scan with a foot search appears to reduce the instances that birds are observed when searchers are not consistently walking a beach segment, but also scanning from one point along the segment to observe birds.

Comparing the percent of cases in which birds were and were not found, in all five search method categories, revealed that foot searches appear to be a good method in observing birds, followed by combination foot/point scan searches, although adding point scans to a search along a beach segment appears to dilute the foot survey data, as the $t$-Test results also showed. Point scan searches by themselves yielded the poorest results by searchers. In two of the four cases of vehicle and combination foot/vehicle searches, birds were observed. These methods may have potential.

Second, an analysis of the literature revealed that reliable monitoring programs require certain essential components to produce reliable, quantifiable 
data. Authors agreed that monitoring programs should be developed around four key components to ensure programmatic success: design, implementation, evaluation, and barriers (Vora 1997, Griffith 1998, Wells 1999, EPA 1996, Ringold et al. 1999, Natural Resources Defense Council 1999, Rees and Pond 1995, Nelson 1993, Krogh and Koop 1996, Agnew 1997, Lee and Pritchard 1996, Ogden et al. 1994, Epstein 1995, Malone and Nemazie 1996, Armstrong et al. 1996, Gilfillan et al. 1999, Gulf of the Farallones National Marine Sanctuary n.d.) (Table 5).

Program design is the framework around which the monitoring program exists and the value it adds to its field of research. This includes a clear definition of a program's purpose, goals, and objectives, proposed method of monitoring and analysis, i.e., how the monitoring program's purpose will be achieved, analysis tool, i.e., how the data will be handled, desired data outcome, i.e., impact of the data, and outcome measure to determine the success of the program's purpose. In comparison, the S.S. Jacob Luckenbach beach search effort included a defined purpose, goal, objective, method, but lacked an analysis tool, outcome, and outcome measure.

Monitoring program implementation, according to the literature, includes data sampling and analysis techniques, or a program's effectiveness to produce the desired results; collaborative opportunities, the program's ability to effectively and efficiently gather data; flexibility and adaptability, the program's ability to change priorities to recognize changed circumstances, and training, 
which ensures proper data collection to yield data as free from error as possible. When compared to the S.S. Jacob Luckenbach beach search effort, this effort identifies five sampling techniques, or search methods, to find birds, but no analysis of that data; demonstrates collaboration with the U.S. Fish and Wildlife Service, the California Department of Fish and Game's Office of Oil Spill Prevention and Response, the non-profit organization Oiled Wildlife Care Network, and the private consulting firm, Mad River Biologists; has no obvious indication from the California Department of Fish and Game how its priorities will change in the face of changed circumstances, and includes some verbal instruction by the California Department of Fish and Game in field methods and equipment use based on an earlier, multi-agency written protocol for documenting beached birds.

Evaluating a monitoring program is important if the program is to effectively produce desired results. Assessment criteria and recommendations are two methods of program evaluation. Assessment criteria, according to the literature, measure the program's statistical power and recommendations provide options for continuous program improvement, including lessons learned. Neither these evaluation tools are identified as part of the S.S. Jacob Luckenbach beach search effort. Testing the beach search effort's searcher efficiency rate for its effectiveness to accurately collect data and surveying searchers in field search 
methods and data collection protocols are examples of evaluation tools for program design and implementation improvement.

Monitoring program barriers must be identified and understood in order to conduct continuous process improvements and recommend implications, policy and budget, for example, based on those barriers. Barriers include poor program design, e.g., lack of clear purpose and objectives or inconsistent or non-existent methods; environmental discrepancy, the ability to distinguish between natural perturbations and human induced environmental changes, and institutional changes in programmatic and financial priorities, which can restrict a program's time frame and yield short-term results. The S.S. Jacob Luckenbach beach search effort lacked clear program design, especially with respect to field methodologies and data analysis; the beach search effort also experienced environmental barriers with respect to beach access and loss of birds due to re-wash, burial, or scavenging, and faced institutional challenges due to lack of dedicated and consistent financial and personnel resources to conduct an effective data collection effort.

Finally, some methodological changes to the S.S. Jacob Luckenbach beach search effort would ensure that this is a reliable program that can produce quantifiable data. Based on the review of the literature, these changes include, providing searcher training in field methods, including consistent and standardized search methods; training searchers to enter data correctly, accurately, and completely in 
the Beach Search Effort Logs to ensure a complete data set; determining a known searcher efficiency rate by incorporating a pilot study of searcher efforts and their ability to detect birds, and establishing a data quality check to ensure data is legible, correct, and complete. 


\section{RECOMMENDATIONS}

The quality and quantity of data collected in the beach search effort prevented the determination of a quantifiable index for the number of birds impacted by S.S. Jacob Luckenbach. However, the beach search did identify a purpose, goal, objective, method, outcome measurement, data sampling technique, means for collaboration, and informal training; specific changes in data sampling methods could produce data that address the program's goal.

Data quality and quantity of the beach search effort was hampered by the use of inconsistent Beach Search Effort Logs; illegible, inaccurate, and incomplete data entries, and a lack of standardized field search methods. To ensure that future beach search efforts are quantifiable, with respect to rate of oiling by the S.S. Jacob Luckenbach, several programmatic changes are recommended.

First, clearly define, standardize, and document data collection protocols, i.e., field search method, how long, how far, with what equipment, and how. For example, foot searches for approximately 110 minutes covering an estimated 2,070 meters yielded the greatest number of observed birds based on the research data analysis. Collect the data on a single standardized Beach Search Effort Log using the appropriate equipment, e.g., GPS hand-held device. Test which field search methods are most and least effective and use the single method that 
provides the best detection of oiled beached birds. Finally, be certain all data are collected to answer the monitoring program's research objectives.

Second, train searchers consistently and continuously in the established data collection protocols, including field search methods, data entry, and proper equipment use. For example, collecting data through consistent application of the foot search method, including time and distance, documentation of legible, accurate, and complete data into a standardized Beach Search Effort Log, and appropriate use of field equipment, will yield of highest set of quantifiable data as free from human error as possible.

Third, develop an evaluation tool to check the collected data for accuracy. The evaluation tool serves as a measure of what is $100 \%$ accurate so that a data analysis can be conducted with reliable results in determining an index for the total number of birds impacted by oiling. For example, establish a data check to ensure data are legible, correct, and complete and periodically test the beach search effort's searcher efficiency rate for its effectiveness to accurately collect data to validate existing field search method types and data collection protocols or reveal opportunities for improvement. Surveying searchers in field search methods and data collection protocols is another evaluation tool to collect data on areas for program design and implementation improvement. Finally, document and implement these lessons-learned to demonstrate effective 
program management, maintain public accountability, and improve future beach search efforts.

Finally, determine a searcher efficiency rate by testing searchers with known numbers of oiled birds placed in a test area. This efficiency rate must be factored into any estimate of the actual number of birds affected by oiling from the S.S. Jacob Luckenbach. 


\section{REFERENCES}

Agnew, David J. "Review: The CCAMLR Ecosystem Monitoring Programme" Antarctic Science 9 (1997): 235-242.

Andrew, N.L. and B.D. Mapstone. "Sampling and description of spatial pattern in marine ecology." Oceanography Marine Biology Annual Review 25 (1987): 39-90.

Armstrong, Ian, and Stephen Higham, Grant Hudson, and Troy Colley. "The Beachwatch Pollution Monitoring Programme: Changing Priorities to Recognize Changed Circumstances." Marine Pollution Bulletin 33 (1996): 249-259.

Bildstein, Keith L. "Long-Term Counts of Migrating Raptors: A Role For Volunteers In Wildlife Research." The Journal of Wildlife Management 62 (April 1998): 435-445.

Carter, H.R., P.J. Capitolo, M.W. Parker, R.T. Golightly, and J.L. Yee. "Population Impacts to Common Murres at the Drake's Bay colong complex, California." Seabird Injuries from the 1997-1998 Point Reyes Tarball Incidents (2003): 43-68.

Carter, H.R., and R.T. Golightly. "Seabird injuries from the 1997-1998 Point Reyes Tarball Incidents." Arcata, CA: Humboldt State University, Department of Wildlife, 2003.

EPA (U.S. Environmental Protection Agency). 1996. EMAP Currents: An Online Document with Information on EMAP. Available on the Internet, HTML address: http://www.epa.gov/emap.

Epstein, Paul R. "Emerging Diseases and Ecosystem Instability: New Threats To Public Health." American Journal of Public Health 85 (February 1995): 168-172.

Ford, R.G., and G.K. Himes Boor. "Trajectory Backcast." Seabird Injuries from the 1997-1998 Point Reyes Tarball Incidents (2003): 29-42.

Ford, R.G., and J.C. Ward. "Bird carcass detection rates following the $M / V$ Kure/Humboldt Bay oil spill" 2000. 
Gilfillan, E.S., and, E.J. Harner, J.E. O'Reilly, D.S. Page, and W.A. Burns.

"A Comparison of Shoreline Assessment Study Designs Used for the Exxon Valdez Oil Spill." Marine Pollution Bulletin 38 (May 1999): 380-388.

Green, R.H. Sampling design and statistical methods for environmental biologists. John Wiley \& Sons, New York, 1979.

Griffith, Jerry A. "Connecting Ecological Monitoring and Ecological Indicators: A Review of the Literature." Journal of Environmental Systems 26 (1998): 325-363.

Hampton, Steve, Ford, G.R., Carter, H.R., Abraham, Christine, and Humple, Diana. "Chronic Oiling and Seabird Mortality from the Sunken Vessel S.S. Jacob Luckenbach in Central California." (2003)

Hockings, Marc. "Evaluating Management of Protected Areas: Integrating Planning and Evaluation." Environmental Management 22 (1998): 337-345.

Hurlbert, S.H. "Pseudoreplication and the design of ecological field experiments." Ecological Monograph 54 (1984) 187-211.

Klee, Gary A. The Coastal Environment: Toward Integrated and Coastal Marine Sanctuary Management. New Jersey: Prentice Hall, Inc., 1999.

Krogh, Martin and Klaus Koop. "Design and Analysis of the Sydney Deepwater Ocean Outfall Environmental Monitoring Programme: a Critique." Marine Pollution Bulletin 33(1996): 273-280.

Lee, R.S. and T.R. Pritchard. "How Do Long-term Patterns Affect Time Limited Environmental Monitoring Programmes?" Marine Pollution Bulletin 33 (1996): 260-268.

Malone, Thomas C., and David A. Nemazie. "Toward a National Agenda for Research in the Coastal Zone: Where Are We?" The Biological Bulletin 190 (April 1996): 245-251.

McCleneghan, Kim, Ph.D. "Ghost of the SS Jacob Luckenbach: The Hunt for Clues to a Killer." Oil Spill Intelligence Report 25 (2002): 1-4.

McGregor, Gregor I. Environmental Law and Enforcement. Florida: CRC Press, Inc., 1994. 
Messer, J.J. et al. 1991. An EPA Program for Monitoring Ecological Status and Trends. Environmental Monitoring and Assessment. Vol. 17(1): 67-78.

Monterey Bay Aquarium Foundation. A Natural History of the Monterey Bay National Marine Sanctuary. Monterey: Monterey Bay Aquarium Foundation, 1997.

Nelson, Walter G. "Beach Restoration in the Southeastern US:

Environmental Effects and Biological Monitoring." Ocean and Coastal Management 19 (1993): 157-182.

National Oceanic and Atmospheric Administration: http://www.sanctuaries.noaa.gov

NRDC (Natural Resources Defense Council). 1999. NRDC Programs: An Online Report with Information on Water Quality at Vacation Beaches. Available on the Internet, HTML address: http://www.epa.gov/emap.

Ogden, John C., James W. Porter, Ned P. Smith, Alina M. Szmant, Walter C.Jaap, and David Forcucci. "A Long-Term Interdisciplinary Study Of The Florida Keys Seascape." Bulletin of Marine Science 54 (May 1994): 1059 - 1071.

Page, G.W., L.E. Stenzel, and D.G. Ainley. "Beached bird carcasses as a means of evaluating natural and human-caused seabird mortality." (1982)

Rees, Gareth, and Kathy Pond. "Marine Litter Monitoring Programmes - A Review of Methods with Special Reference to National Surveys." Marine Pollution Bulletin 30 (February 1995): 103-108.

Ringold, Paul L., Barry Mulder, Jim Alegria, Raymond L. Czaplewski, Tim Tolle, and Kelly Burnett. "Establishing a Regional Monitoring Strategy: The Pacific Northwest Plan." Environmental Management 23 (January 1999): 179-192.

Sherman, Kenneth. 1994. Sustainability, biomass yields, and health of coastal Ecosystems: an ecological perspective. Marine Ecology Progress Series. Vol. 112: 277-301.

Smith-Evans, Marc and Adrian Dawes. 1996. Early Experiences in Monitoring the Effects of Hong Kong's New Generation of Sewage Outfalls on the Marine Environment. Marine Pollution Bulletin. Vol. 23(7-12): 317-327. 
The National Park Service. April 2001. http//www.nps.gov/.

Vora, Robin. "Developing Programs to Monitor Ecosystem Health and Effectiveness of Management Practices on Lakes States National Forests, USA." Biological Conservation 80 (January 1997): 289-302.

Wells, Peter G. "Biomonitoring the Health of Coastal Marine Ecosystems - The Roles and Challenges of Microscale Toxicity Tests." Marine Pollution Bulletin 39 (1999) 39-47. 
APPENDIX A

Beach Search Effort Logs 
Please record all beaches searched even if no birds are found.

Spill Name: Luckenbach

Date: January 1, 2003

Searchers: $\quad$ K. Jennings (OSPR) and J. Muskat (OSPR)

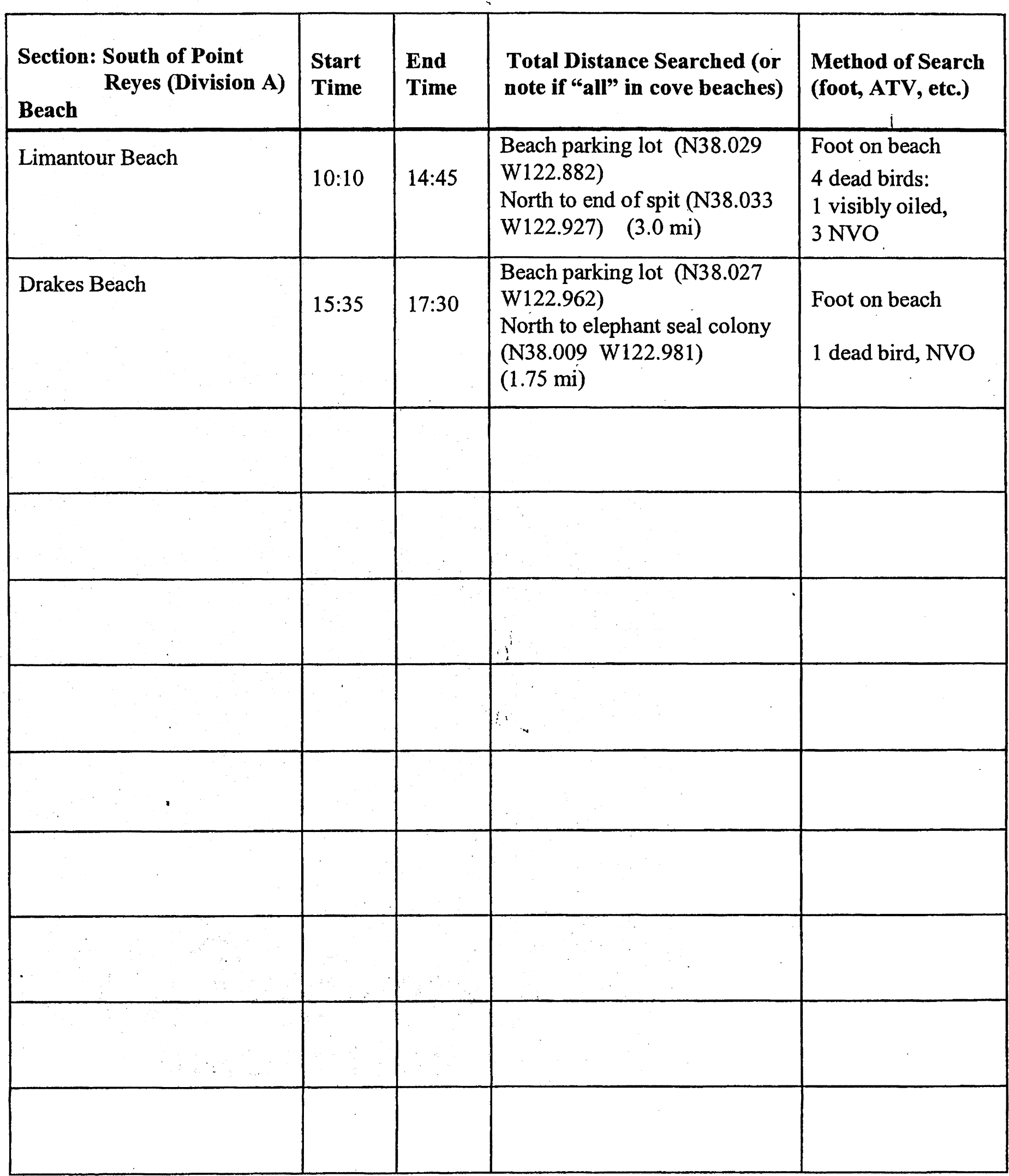




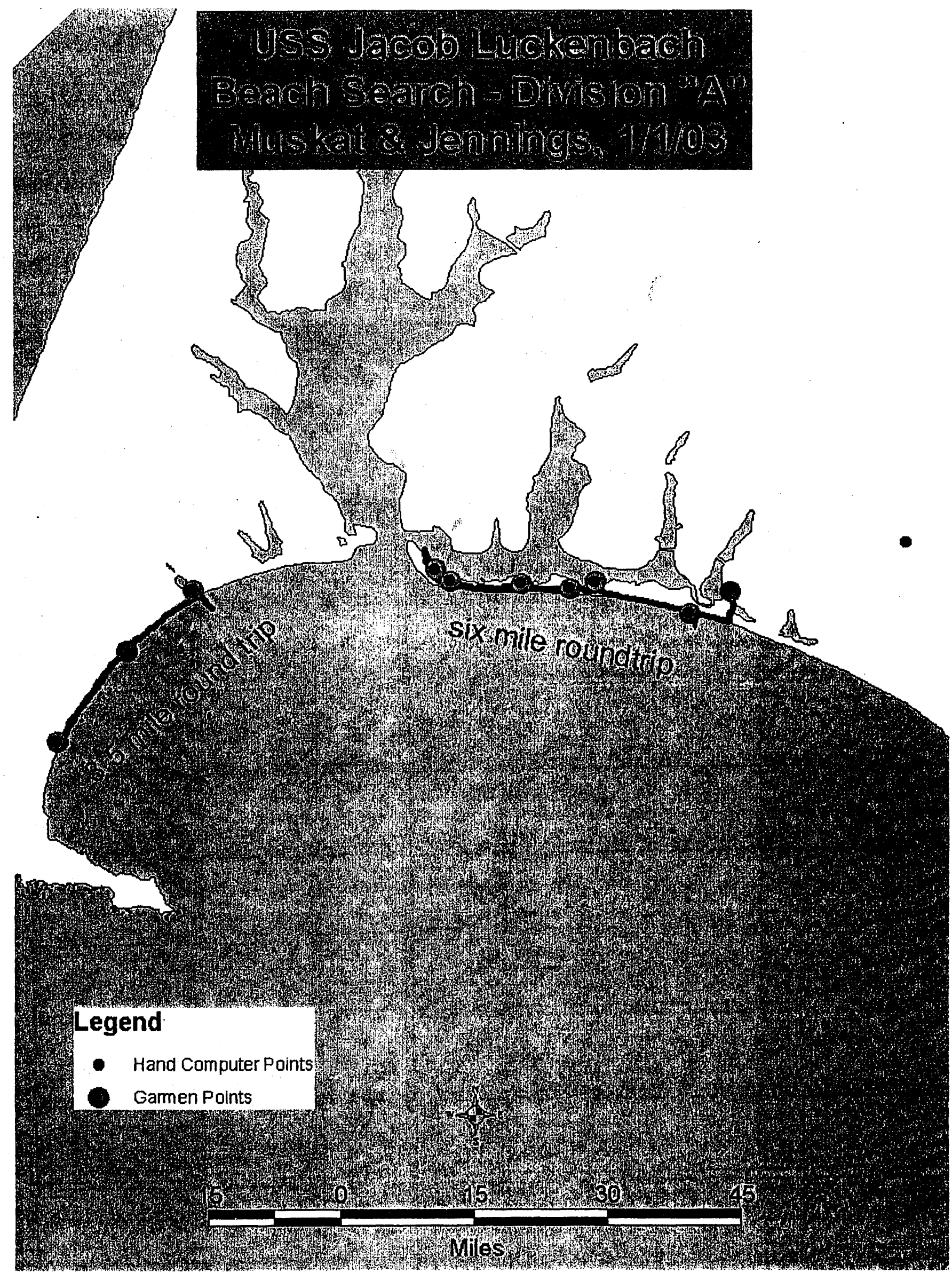




\section{Beach Search Effort Log}

Search Number:

Please record all beaches searchod even is no birds are found.
Spill Name Lucheubad
Date: $12 / 31 / 02$

Searchers: Ward / Griehl

Nore: Time sbould inclade all time spent on the bach, even whon backracking. North and south cndpoints should be GPS pto. If not, lease provide a rood descriplion of the anes covered. For collecred blinds pur GPS location here and on Chnin of Custody form.

\begin{tabular}{|c|c|c|c|c|c|c|c|c|}
\hline & Beach Name & $\begin{array}{l}\text { Start } \\
\text { Thure }\end{array}$ & $\begin{array}{l}\text { Dnd } \\
\text { Time }\end{array}$ & $\begin{array}{l}\text { North Extreme } \\
\text { of Area } \\
\text { Searched }\end{array}$ & $\begin{array}{l}\text { South Extreme } \\
\text { of Area } \\
\text { Searched }\end{array}$ & $\begin{array}{l}\text { Total } \\
\text { Dhatance } \\
\text { Searebod }\end{array}$ & $\begin{array}{l}\text { Method } \\
\text { (roos, } \\
\text { ATV, } \\
\text { scem, erce) }\end{array}$ & $\begin{array}{l}\text { Birds Collocted } \\
\text { five of deand) }\end{array}$ \\
\hline A & $\begin{array}{l}\text { Waddel } \\
\text { Beadh }\end{array}$ & 1040 & 1105 & & $\begin{array}{l}N 37.09559 \\
\text { W122.27704 }\end{array}$ & $3 / 4$ & $\begin{array}{l}\text { scan } \\
\text { 8poot }\end{array}$ & $\begin{array}{l}2 \text { copre } \\
\text { कox }\end{array}$ \\
\hline B & $\begin{array}{l}\text { Grester } \\
\text { Rock }\end{array}$ & 1109 & 1116 & $\begin{array}{l}\text { N32.079 } \\
\text { W122,26434 }\end{array}$ & & $3 / 4$ & Scan & $\phi$ \\
\hline C & $\begin{array}{l}\text { Scoits } \\
\text { Greek }\end{array}$ & 1119 & 1125 & $\begin{array}{l}N 37,039 \\
W 122,2274\end{array}$ & & $1 / 4$ & Scam & $\Phi$ \\
\hline D & $\begin{array}{l}\text { Pavenport } \\
\text { conding }\end{array}$ & 1128 & 1134 & $\begin{array}{l}N 37.01102 \\
W i 22.9440\end{array}$ & & & scoen & $\phi$ \\
\hline $\mathbf{E}$ & $\begin{array}{l}\text { Wizder } \\
\text { Raudh }\end{array}$ & $114 i$ & & & & & & \\
\hline $\mathbf{F}$ & $\begin{array}{l}\text { Natkernl } \\
\text { Brideres }\end{array}$ & 1158 & 1206 & $\begin{array}{l}N 36.949 \\
4122.0559\end{array}$ & & & scan & $\phi$ \\
\hline $\mathbf{G}$ & $\begin{array}{l}\text { fiskesmons } \\
\text { somta Cruer }\end{array}$ & 1211 & 1232 & $\begin{array}{l}w 36,9618 \\
\omega 122.020 .5\end{array}$ & 6 & $3 / 4$ & Poot & $\varnothing$ \\
\hline $\mathbf{H}$ & $\begin{array}{l}\text { Harbor } \\
\text { Sauta Cruz }\end{array}$ & 1239 & 1253 & $\begin{array}{l}\text { N36.965g } \\
\text { N122.000 }\end{array}$ & $\frac{1}{2}$ & 1 & $\begin{array}{l}\text { feot } \\
\text { escan }\end{array}$ & $\varnothing$ \\
\hline $\mathbf{I}$ & $\begin{array}{l}\text { Harbor } \\
\text { Moss Lauding }\end{array}$ & 1427 & 1442 & $\begin{array}{l}N 36.8078 \\
w 12 t .785\end{array}$ & & & f & $\begin{array}{l}\text { STBRCO } \\
\text { SRCO } / D\end{array}$ \\
\hline $\mathbf{J}$ & $\begin{array}{l}\text { Kasbar } \\
\text { Moss hauding }\end{array}$ & 1446 & 1620 & $\begin{array}{l}1036.806949 \\
121.78771\end{array}$ & & & $\begin{array}{l}\text { for } \\
\text { fsean }\end{array}$ & $\begin{array}{l}8 R \operatorname{RC}(\mathrm{C}) \\
\text { for dead } 6\end{array}$ \\
\hline $\mathbf{K}$ & $\begin{array}{l}\text { Moss Lauding } \\
\text { Hastor }\end{array}$ & 1627 & 7718 & $\mid \begin{array}{l}N 36,81724 \\
121.78643\end{array}$ & $\begin{array}{l}N 36.80910 \\
W 121.78773\end{array}$ & & $\begin{array}{l}\text { foot } \\
\text { fscem }\end{array}$ & $\phi$ \\
\hline
\end{tabular}


. 02/2003 09:06 INTL BIRD RESCUE RESEARCH CNTR $\rightarrow 19163248829$

(4)

conve

DOA

1055 Waddel Beach

$N 37.09626$

W 122.27705 . L

come 11.00 . Waddel Beach N37.09625 M DOA

W 122.27704

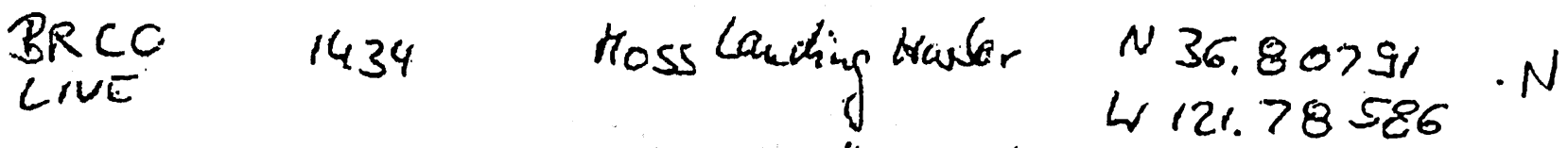

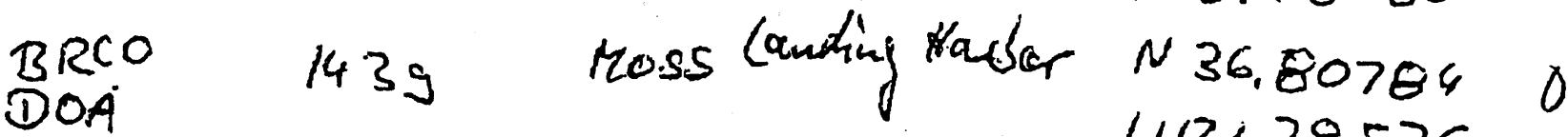

WII: 78576

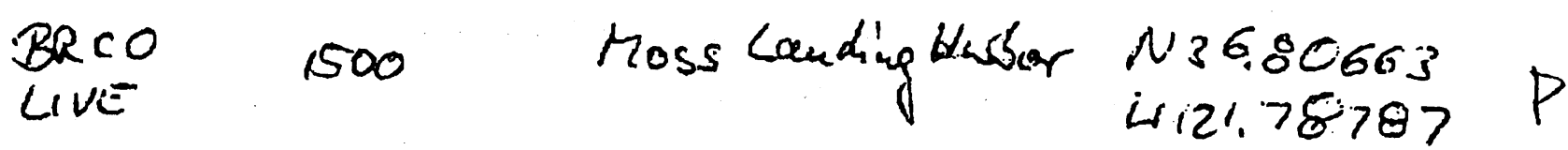

$\begin{array}{ll}\text { BRCO } & 1515 \quad \text { hoss landing Hasbor } \begin{array}{l}N 36.80635 \\ \text { DOA }\end{array} \quad \text { Wi21.78774 }\end{array}$

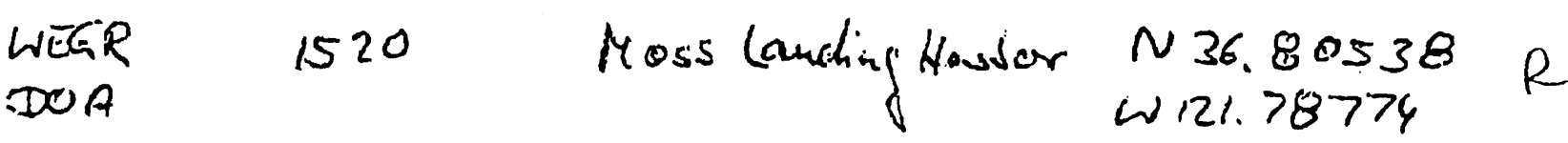

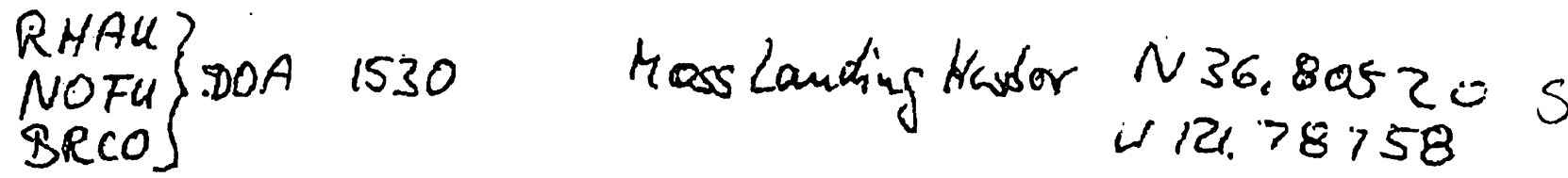

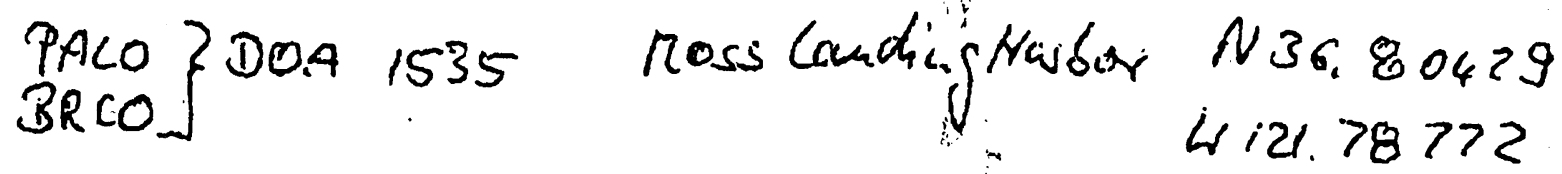

BRCO DOA, 1538 MOS's Lanctingttouter N.36. 80411 NOFE DOA 1540 MOSSlanding W121.78755 U Nabor N36. 20595 Wi2. $78006 \mathrm{~V}$ 


\section{California Department of Fish and Game} Office of Spill Prevention and Response $3 \mathrm{C}$

\section{GPS Waypoint Logbook}

\section{Spill / Project Name:}

tuken horek If

Operator Name;

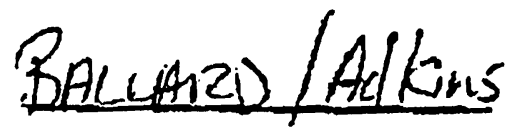

GPS Unit Serial No.:

Date Checked Out:

$12 \cdot 31-02$

Date Returnod:

Date/Time Downloaded:

Downloaded By:

Book of 


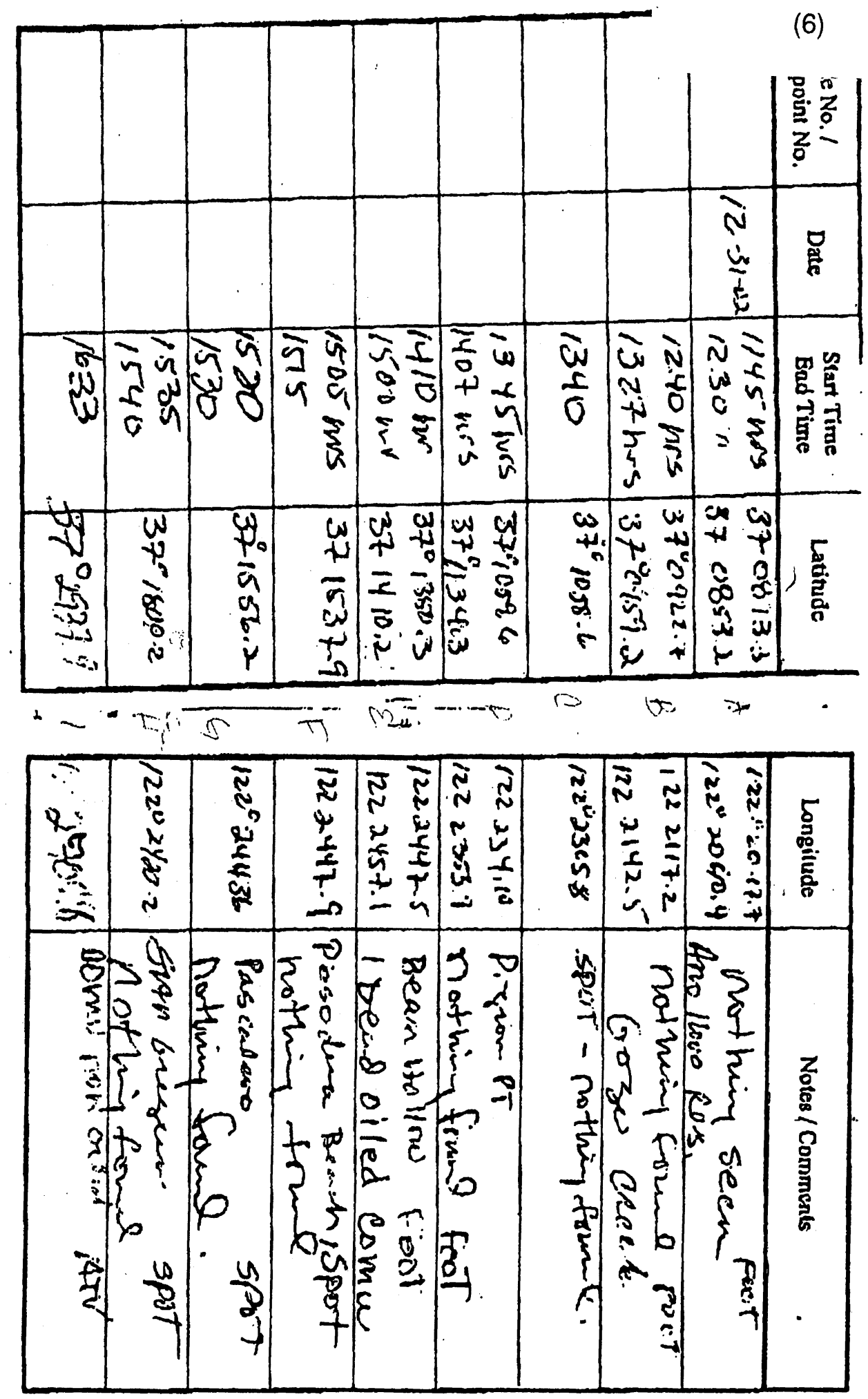



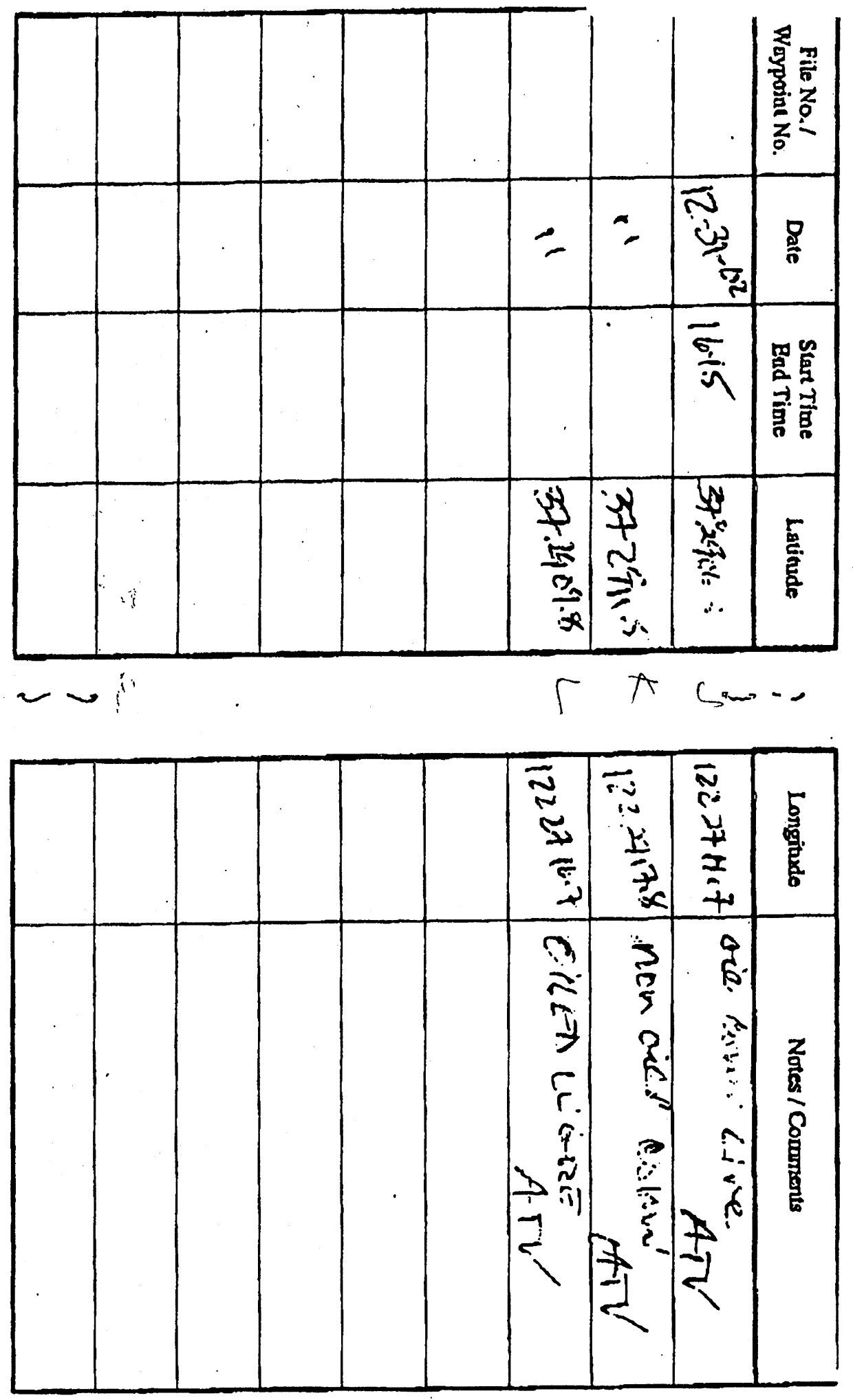


\section{Beach Search Effort Log}

Search Number:

Please record all beaches searched even if no birds are found.

Spill Name: LUCKENBACH

Date: $\frac{12 / 26 / 02}{}$

Searchers: R.IMAI / J.HAAS

Note: Time should include all time spent on the beach, even when backtracking. North and south endpoints should be GPS pts. If not, please provide a good description of the area covered. For collected birds, put GPS location here and on Chain of Custody form.

\begin{tabular}{|c|c|c|c|c|c|c|c|c|}
\hline & Beach Name & $\begin{array}{l}\text { Start } \\
\text { Time }\end{array}$ & $\begin{array}{l}\text { End } \\
\text { Time }\end{array}$ & $\begin{array}{l}\text { North Extreme } \\
\text { of Area } \\
\text { Searched }\end{array}$ & $\begin{array}{l}\text { South Extreme } \\
\text { of Area } \\
\text { Searched }\end{array}$ & $\begin{array}{l}\text { Total } \\
\text { Distance } \\
\text { Searched }\end{array}$ & $\begin{array}{l}\text { Method } \\
\text { (foot, } \\
\text { ATV, } \\
\text { scan, etc.) }\end{array}$ & $\begin{array}{l}\text { Birds Collected } \\
\text { (live \& dead) }\end{array}$ \\
\hline $\mathbf{A}$ & OCEAN BEACH & 0920 & 1115 & & & 3 MILE & FOOT & $\begin{array}{l}11 \text { DEAD (4 } \\
\text { OILED) } \\
\text { TIME X2 }\end{array}$ \\
\hline B & FORT FUNSTON & 1130 & 1200 & ' & & $\begin{array}{l}1.2 \\
\text { MILE }\end{array}$ & FOOT & TIME X2 \\
\hline C) & SHARPE PARK & 1215 & 1250 & & & $\begin{array}{l}0.93 \\
\text { MILE }\end{array}$ & FOOT & TIME X2 \\
\hline D & ROCKAWAY & 1210 & 1317 & & & $\begin{array}{l}0.32 \\
\text { MILE }\end{array}$ & FOOT & TIME X2 \\
\hline $\mathbf{E}$ & PACIFICA & 1326 & 1347 & & & $\begin{array}{l}0.74 \\
\text { MILE }\end{array}$ & FOOT & TIME X2 \\
\hline $\mathbf{F}$ & $\begin{array}{l}\text { GREY WHALE } \\
\text { COVE }\end{array}$ & 1400 & 1420 & & 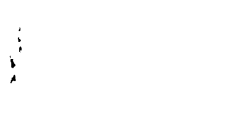 & $\begin{array}{l}0.38 \\
\text { MILE }\end{array}$ & FOOT & TIME X2 \\
\hline G & MONTARA & 1426 & 1450 & & $=$ & $\begin{array}{l}0.85 \\
\text { MILE }\end{array}$ & FOOT & TIME X2 \\
\hline $\mathbf{H}$ & FITZGERALD : & 1511 & 1521 & & & $\begin{array}{l}0.25 \\
\text { MILE }\end{array}$ & FOOT & TIME X1 \\
\hline I & $\begin{array}{l}\text { FITZGERALD / } \\
\text { DISTILLERY }\end{array}$ & 1532 & 1547 & & & $\begin{array}{l}0.25 \\
\text { MILE }\end{array}$ & FOOT & TIME X2 \\
\hline $\mathbf{J}$ & PILLAR POINT & 1603 & 1705 & & & $\begin{array}{l}0.89 \\
\text { MILE }\end{array}$ & FOOT & TIME X1 \\
\hline $\mathbf{K}$ & & & & & & & & $\begin{array}{l}\text { note: time } x 1 \\
\text { searched together; } \\
\text { x2 split n \& S }\end{array}$ \\
\hline
\end{tabular}


ter $\angle 1$, cues

FROM : RAMADA LIMITED HALF NON BAY

FAX NO. : 650 726 5269

Dec. 272692

(9)

Search Nurser:

$2 B$

Beach Search Effort Log

Please record all beaches searched even (" no birds ave found.

Spill Name: Luckembach

Date: $12 / 26 / 02$

Searchers: Sean Mr.Allister, Mania Griehl.

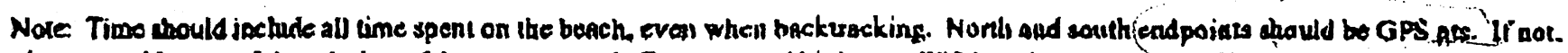

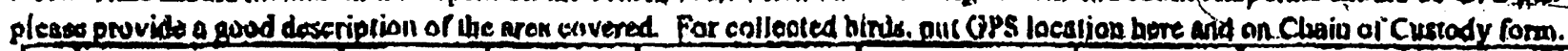

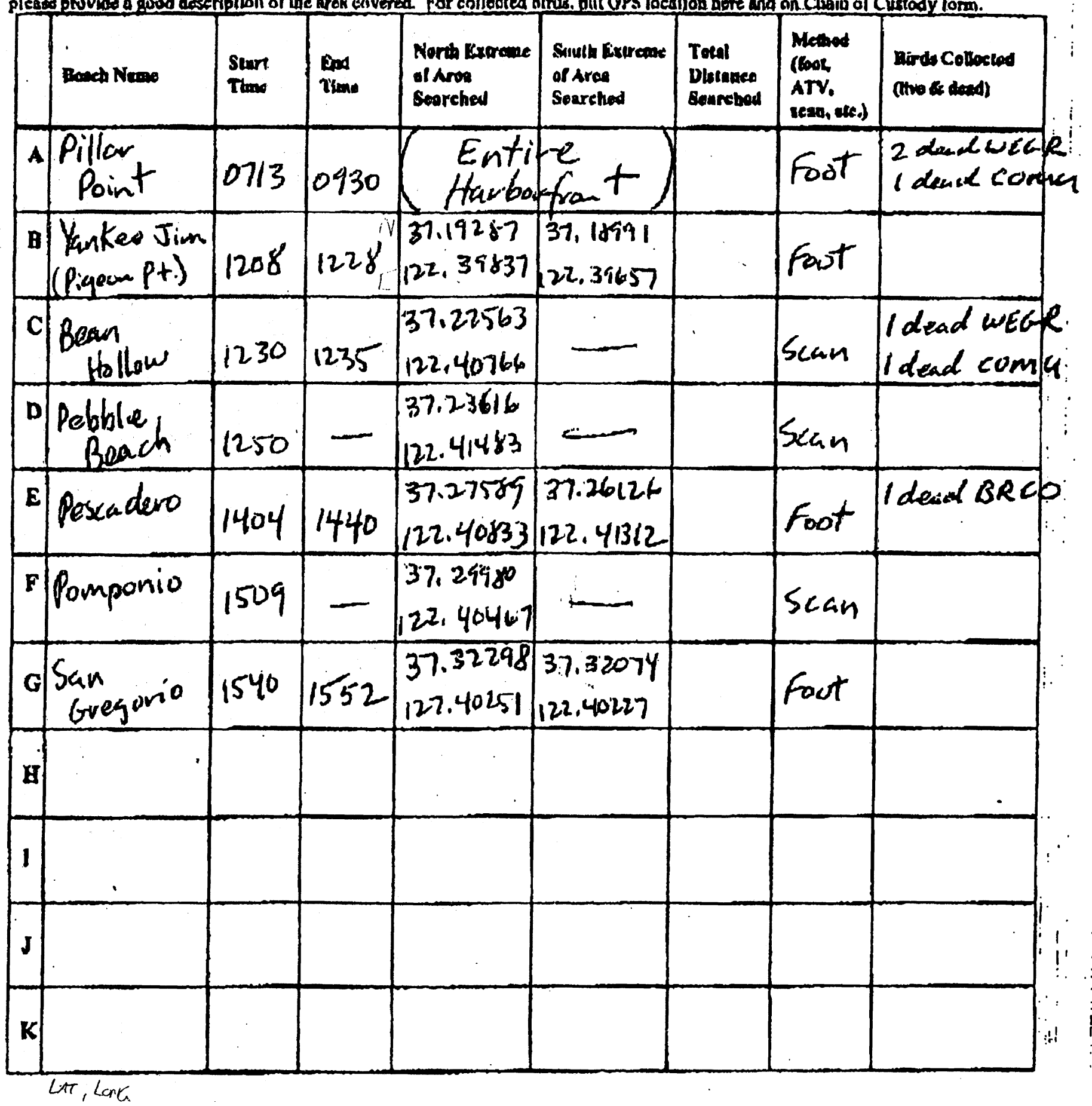

$N_{\text {AMA }}, N, E$ 
8314691723

(10)

Search Number:

Beach Search Effort Log

Please record all beaches searched even if no birds are found.

Spill Name: Lack en bach If

Date 1 $12-26-02$

searchers is trashes, E Fanot-Dawils

Now: Time should include all time spent as the beach, oven when backtracking. North and south endpoints should be GPS pta. If not,

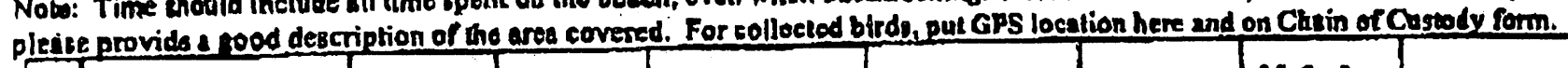

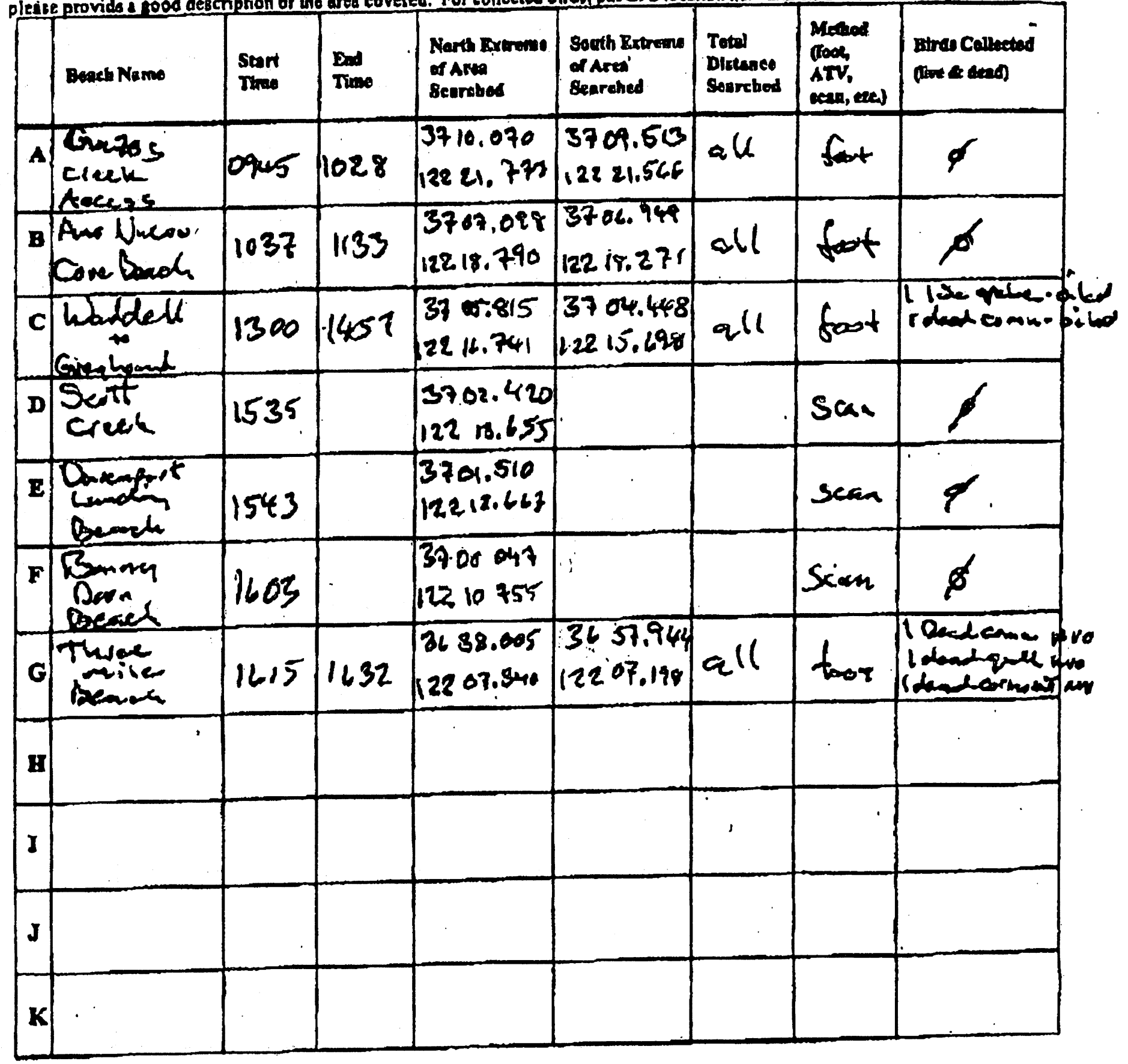




\section{Beach Search Effort Log}

Search Number:

Please rccord all beaches searched even if no hirds are found.

Spill Name: L Leckeken back

Date: 26 Dectember oz

Searchers: Espinose; Velez.

Nate: Time should include all time spent on the beach, even when hacktracking. North and south endpoints should be GPS pts. If not, please provide a good description of the area covered. For collected birds. put GPS location here und on Chain ur Custody form.

\begin{tabular}{|c|c|c|c|c|c|c|c|c|}
\hline & Beach Name & $\begin{array}{l}\text { Start } \\
\text { Time }\end{array}$ & $\begin{array}{l}\text { End } \\
\text { Time }\end{array}$ & $\begin{array}{l}\text { North Extreme } \\
\text { of Arca } \\
\text { Searched }\end{array}$ & $\begin{array}{l}\text { South Extreme } \\
\text { of Area' } \\
\text { Searched }\end{array}$ & $\begin{array}{l}\text { Tntal } \\
\text { Dixtance } \\
\text { Searched }\end{array}$ & $\begin{array}{l}\text { Method } \\
\text { (foot, } \\
\text { ATV, } \\
\text { scan, etc.) }\end{array}$ & $\begin{array}{l}\text { Birds Collected } \\
\text { (live \& dead) }\end{array}$ \\
\hline $\mathbf{A}$ & Del Mante & $09 \%$ & 510 & & & & Foot & \\
\hline B & Lovers Pit & 1030 & 1035 & $\begin{array}{l}\text { Leverspninil } \\
\text { Beach }\end{array}$ & $\begin{array}{l}\text { Lovers Poind } \\
\text { Deach }\end{array}$ & $\begin{array}{l}\text { sprour } \\
\text { 3om }\end{array}$ & Truer.h & \\
\hline C & Pf Poinos & $10+0$ & 1300 & Pt Risios & sisilamer & $\begin{array}{l}\text { Aspros } \\
3 . \mathrm{Km}\end{array}$ & $\begin{array}{l}\text { Truck } \\
\text { Foot }\end{array}$ & $\begin{array}{l}\text { Bead olled } \\
\text { moumer } \\
36.57 .272 \\
12 \times 901.431 .\end{array}$ \\
\hline D & & & & & & & & \\
\hline $\mathbf{E}$ & & & & & & & & \\
\hline $\mathbf{F}$ & & & & & $\vdots$ & & & \\
\hline G & & & & & $y$ & & & \\
\hline $\mathbf{H}$ & & & & & & & & \\
\hline I & & & & & & & & \\
\hline $\mathbf{J}$ & . & & & & & & & \\
\hline K & & & & & & & & \\
\hline
\end{tabular}




\section{Beach Search Effort Log}

Search Number.

Please record all beaches searched even if no birds are found.

Spill Name: Luckenbach

Date: $12 / 31 / 02$

Searchers:S. meAllister /A. Transou

Note: Time should include all time speat on tbe beach, even when backtracking. North and south eadpoints should be GPS pts. If not, please previde a pood deseniption of the srea cavered. For collected birds. put GPS location bere and on Chaiu of Cuscody form.

\begin{tabular}{|c|c|c|c|c|c|c|c|c|}
\hline & Beact Name & $\begin{array}{l}\text { Start } \\
\text { Time }\end{array}$ & $\begin{array}{l}\text { End } \\
\text { Time }\end{array}$ & $\begin{array}{l}\text { North Extreme } \\
\text { of Anez } \\
\text { Searcbed }\end{array}$ & $\begin{array}{l}\text { South Exrome } \\
\text { of Area } \\
\text { Searched }\end{array}$ & $\begin{array}{l}\text { Total } \\
\text { Distance } \\
\text { Searebed }\end{array}$ & $\begin{array}{l}\text { Method } \\
\text { (Soon } \\
\text { ATV, } \\
\text { sean, etc.) }\end{array}$ & $\begin{array}{l}\text { Birds Coloeted } \\
\text { (ive \& dend) }\end{array}$ \\
\hline $\mathbf{A}$ & $\begin{array}{l}\text { Pillar } \\
\text { Point }\end{array}$ & 0630 & 0740 & $\begin{array}{l}\text { Entire } \\
\text { Harburfont }\end{array}$ & & & foot & $\phi$ \\
\hline B & $\begin{array}{l}\text { Baker } \\
\text { Beach }\end{array}$ & 1025 & $1 / 103$ & $\begin{array}{l}37.79801^{\circ} \\
122.48118^{\circ}\end{array}$ & $\begin{array}{l}37.78986^{\circ} \\
122.48679^{\circ}\end{array}$ & 0.7 & foot & $\begin{array}{l}\text { Non-oilod de } \\
37.79804 \\
122.4832\end{array}$ \\
\hline C & $\begin{array}{l}\text { Crissy } \\
\text { field }\end{array}$ & 1112 & 1130 & $\begin{array}{l}37.80767 \\
22.46951\end{array}$ & $\begin{array}{l}37.80654 \\
122.45053\end{array}$ & & foot & $\begin{array}{l}37.80456 \\
122.45760\end{array}$ \\
\hline D & $\begin{array}{l}\text { Point } \\
\text { Richmond }\end{array}$ & 1227 & 1316 & $\begin{array}{l}\text { Scamued } \\
\text { morina } \\
\text { shore. }\end{array}$ & $\begin{array}{l}\text { Richomend } \\
\text { from }\end{array}$ & & Scan & $\begin{array}{l}\text { I Liace oised } \\
\text { collected by } \\
\text { at bout ram }\end{array}$ \\
\hline $\mathbf{E}$ & $\begin{array}{l}\text { Ocean } \\
\text { Beach }\end{array}$ & 1404 & 1459 & $\begin{array}{l}37.77640 \\
122.51186\end{array}$ & $\begin{array}{l}37.73392 \\
122.50757\end{array}$ & & $\begin{array}{l}\text { ATV. } \\
\text { foot }\end{array}$ & $\begin{array}{l}\text { com4 } \\
37.76826 \\
122.51048\end{array}$ \\
\hline $\mathbf{F}$ & l, & I" & $\because$ & $\cdots$. & $\because$ & & 'r & $\begin{array}{l}60 \mathrm{mu} \\
37.74770 \\
122.50935\end{array}$ \\
\hline $\mathbf{G}$ & 16 & ". & "b & W. & $\because 6$ & & 10 & $\begin{array}{l}\text { Nofu } \\
37.76811 \\
122.51044\end{array}$ \\
\hline $\mathbf{H}$ & 4 & "، & "0 & 4 & u & & ८ & $\begin{array}{l}\text { Nofu } \\
37.75563 \\
122.57023\end{array}$ \\
\hline I & "1 & at & "I & « & "4 & & Cl & $\begin{array}{l}P A \angle O \\
37.75215 \\
122.50938\end{array}$ \\
\hline $\mathbf{J}$ & $\begin{array}{l}\text { Pillar } \\
\text { Point }\end{array}$ & 1538 & 1615 & $\begin{array}{l}\text { Entine } \\
\text { Heutbortiont }\end{array}$ & r & & Foot & $\varnothing$ \\
\hline $\mathbf{K}$ & $\begin{array}{l}\text { Fifugevald } \\
\text { manive fosene }\end{array}$ & 1624 & 1646 & $\begin{array}{l}37.52696 \\
122.51596\end{array}$ & $\begin{array}{l}37.51797 \\
122.51259\end{array}$ & & foot & $\varnothing$ \\
\hline & Pillar Point & $2 / 30$ & 2215 & Entive & Harbor & & Foot & $\varnothing$ \\
\hline
\end{tabular}




\section{Beach Search Effort Log}

Search Number:

Please rocord all beaches searched even if no birds are found.

Spill Name: Luckeubach

Date: $12 / 22$

Searchers:SAnquacomp/Grieh//Mclalistef Dy nitule

Note: Time should include all eime spept on the beach, evon when backiracking. North and south endpoints should be GPS pts. If nat. please provide a good deseription of the area covered. For collected birds. put GPS locadion here and on Clain of Custody form.

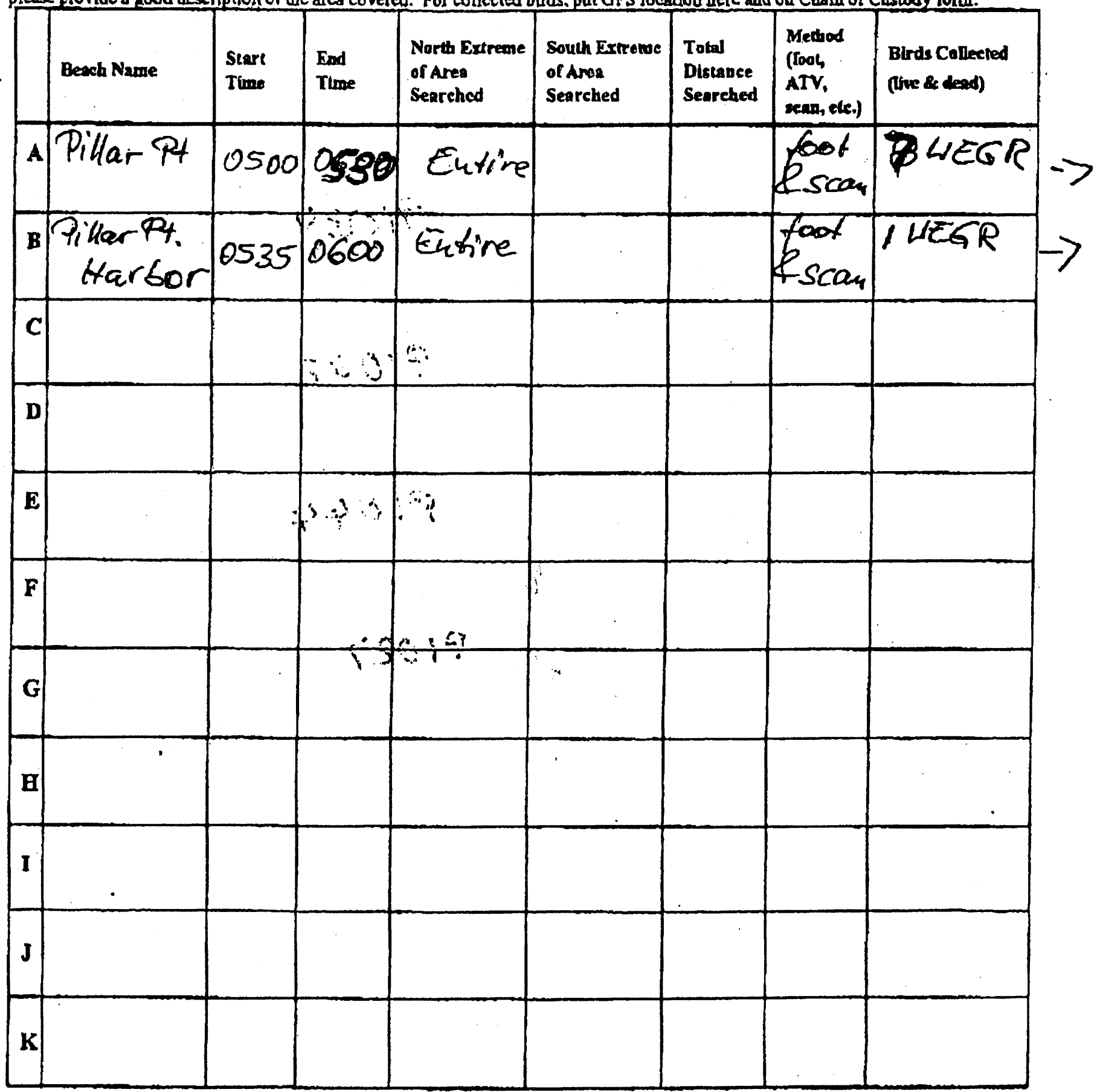




\section{Beach Search Effort Log}

Please record all beaches searched even if no birds are found.

Spill Name: LACKENBACA

Searchers: DANE PRILE, JIM BARS

Date: $123 / 02$

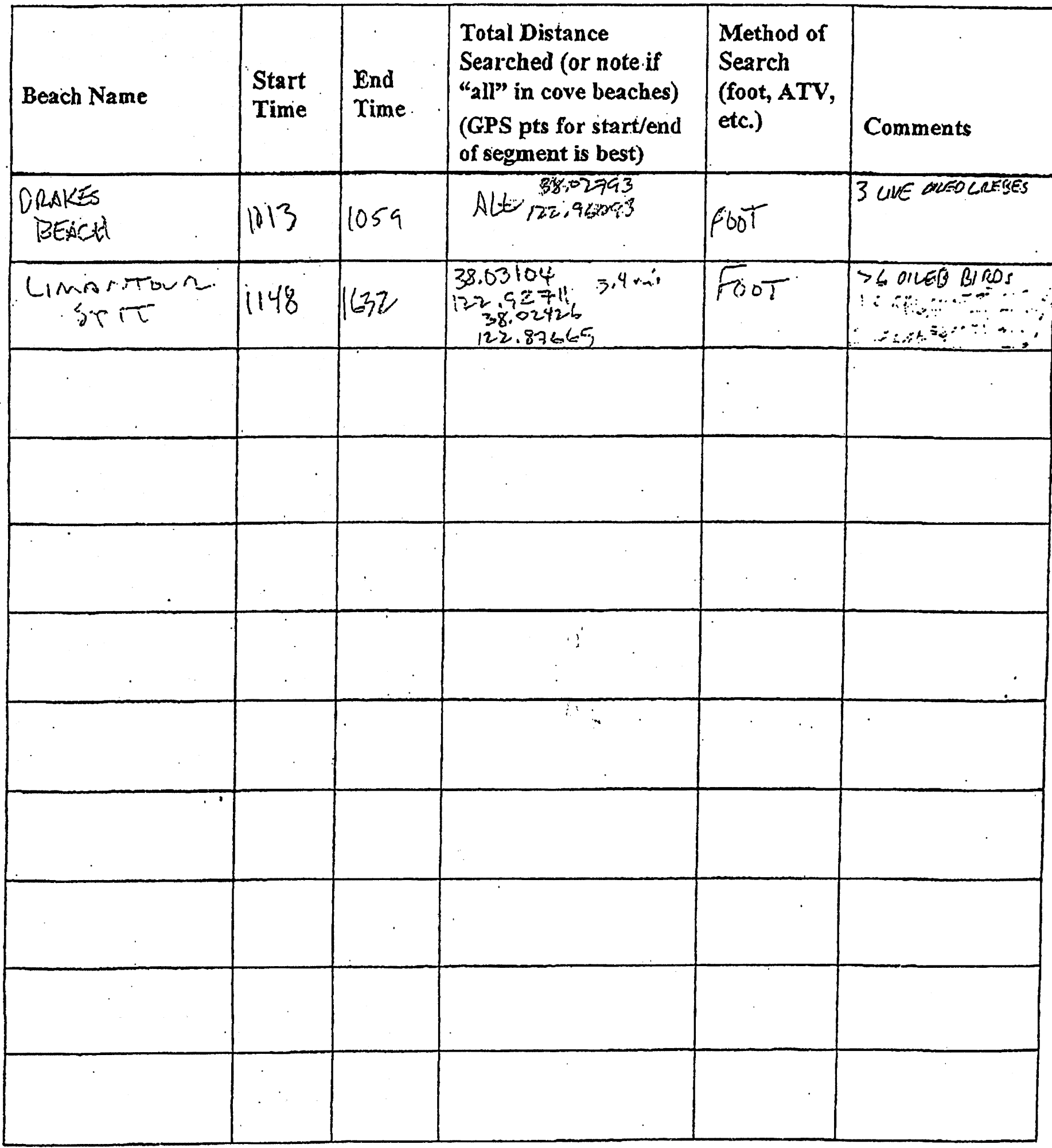




\section{Beach Search Effort Log}

Search Number:

Please record all beaches searched even if no birds are found.

Spill Name: Lucken bach

Date: $12 / 23 / 02$

searchers: Sean Mallistor / Rebecea Dmytryk/T. Williamsan

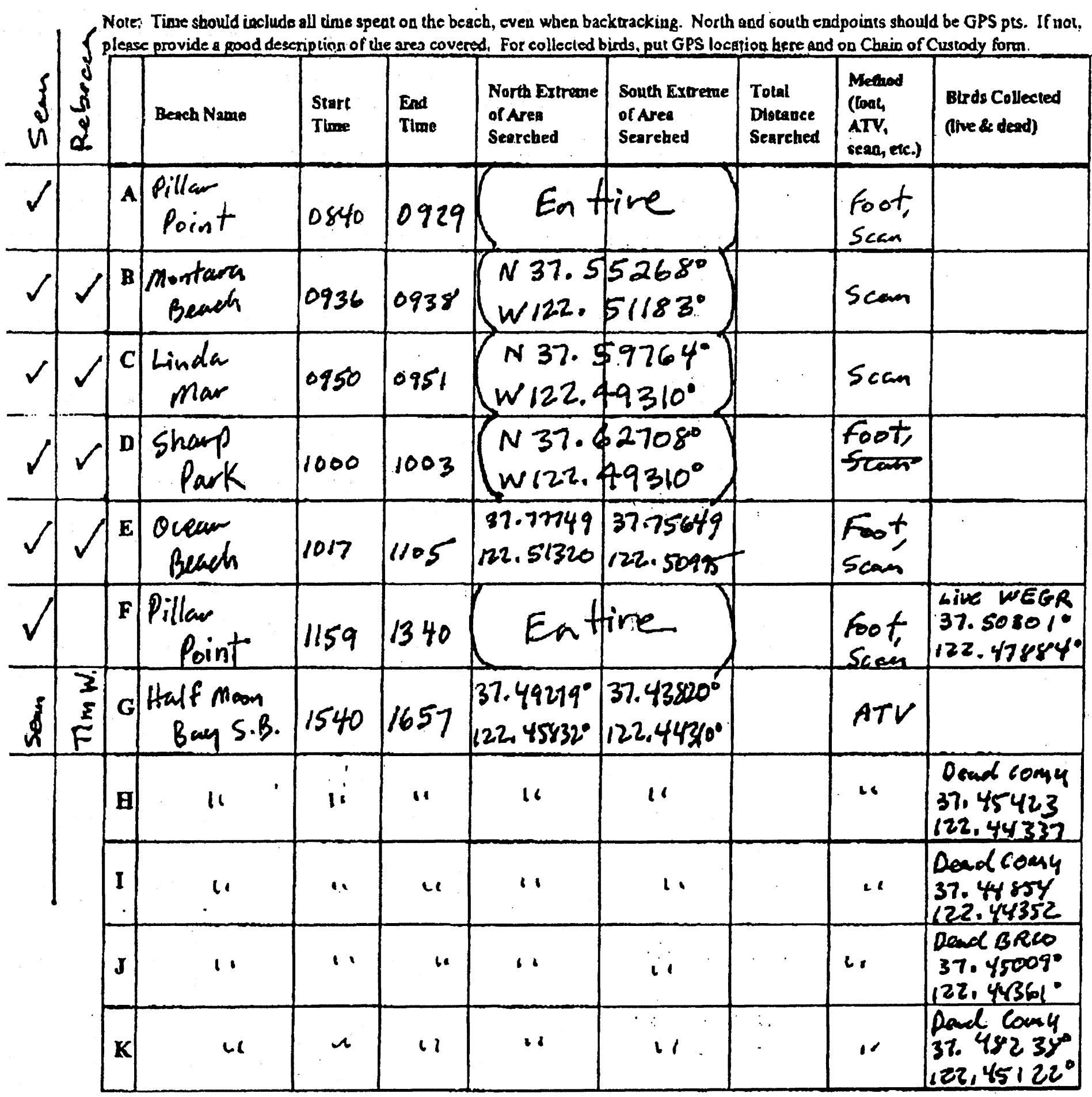




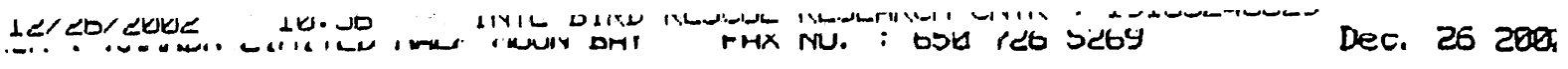

(16)

Beach Search Effort Log

Search Number:

$2 i 3$

Please record all beaches searched even is no binds are found.

Spill Name: Lucke_bach

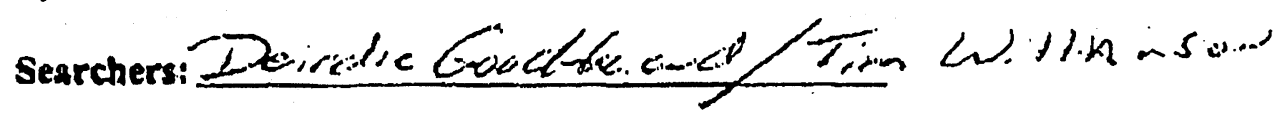

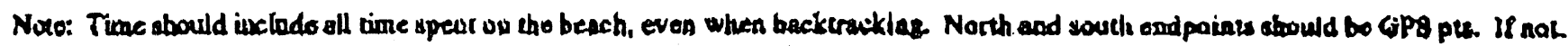

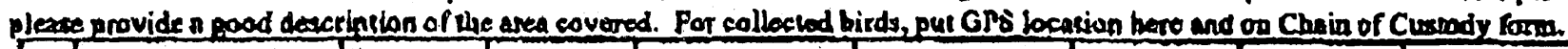

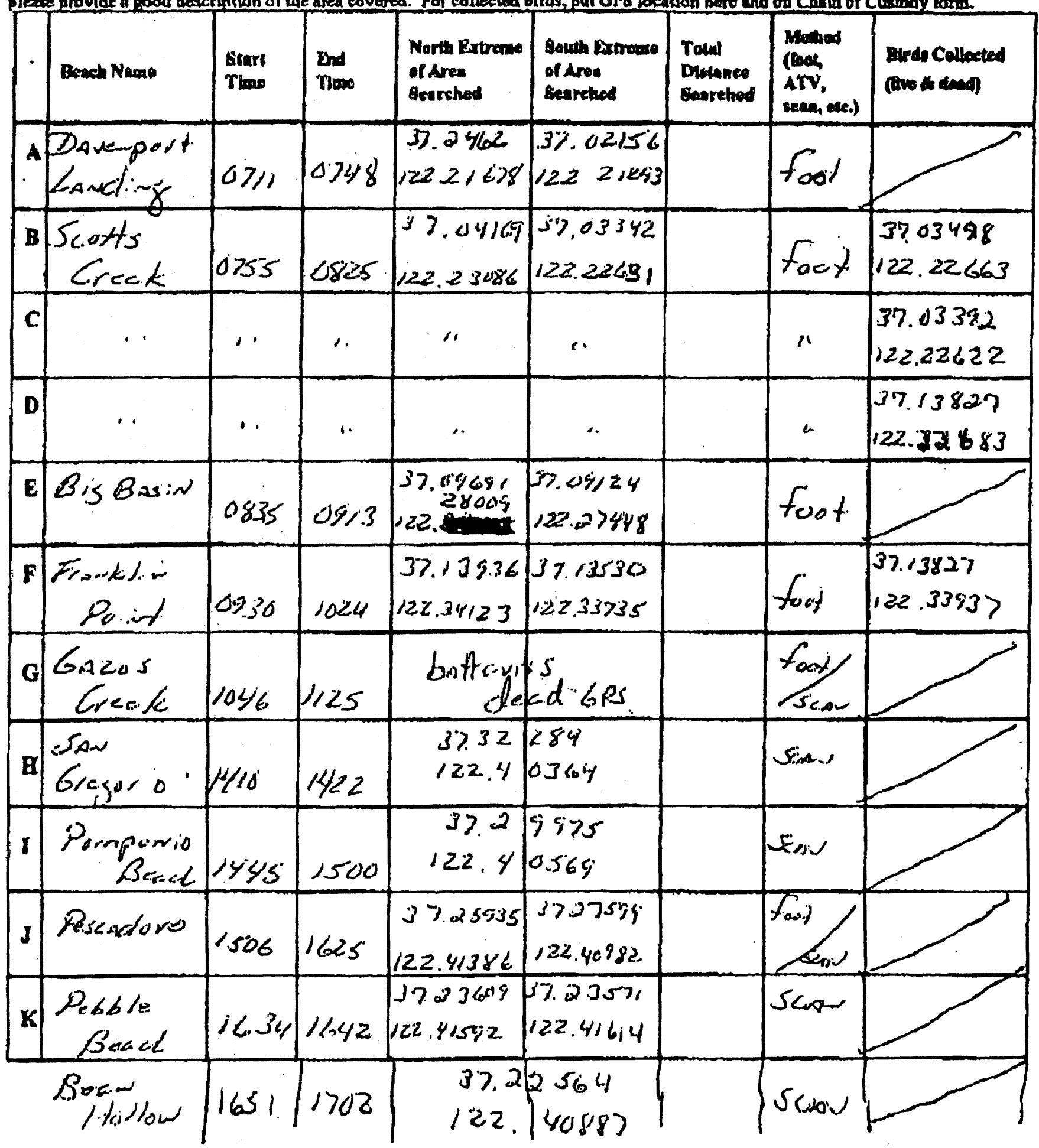




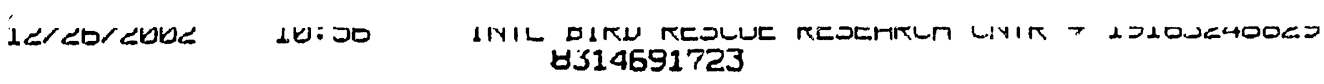

(17)

Beach Search Effort Log

Search Number. 2.13

Please record all beaches searched even if no birds are found.

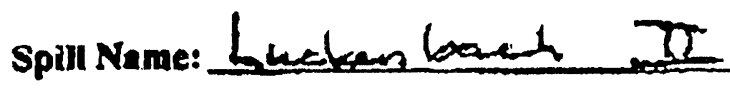

$$
\text { Date: } 12-23-02
$$

Searchers: Dr Hewhos, L Espenas

Note: Time should include all rime spent on the beach, even when backtracking. North and south endpoints should be GPS pts. If not, please provide a good desertpllon of the ana covered. For collected birds pus OPS location here and on Chain of Custody form.

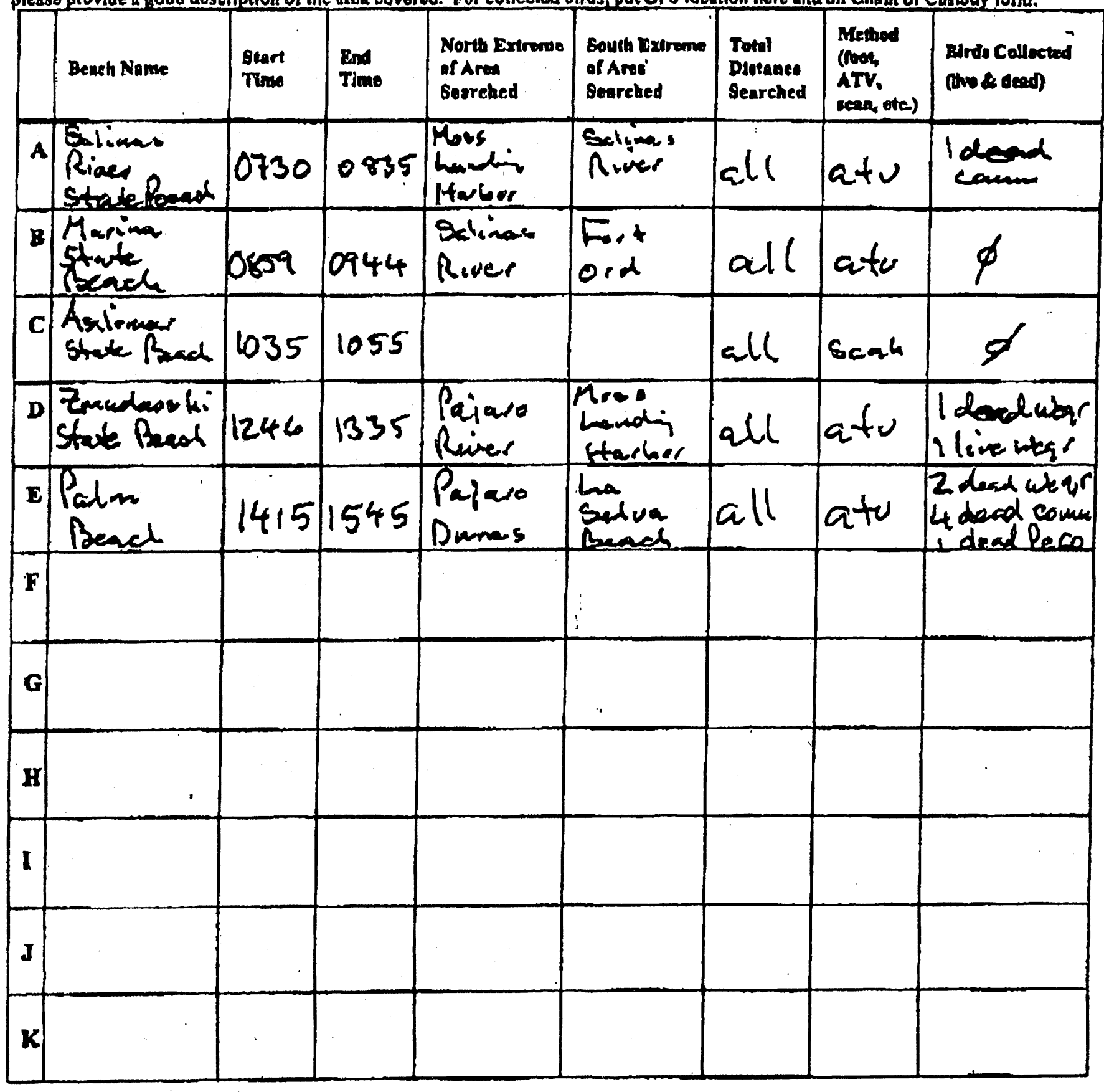


1</

(18)

Beach Search Effort Log

Search Number.

2.8

Please record all beaches searched even if no birds are found.

Spill Name: Lucleen bach

Date: 12/23/02

searchers: Enill/sangiacomo

Note: Tine should include all time spent on the beach, evora when backtracking. North and south endpoints should be GPS pos. If url. please provide a good description of the ane covered. For collected birds. put GPS location here nd an Chain of Custody form.






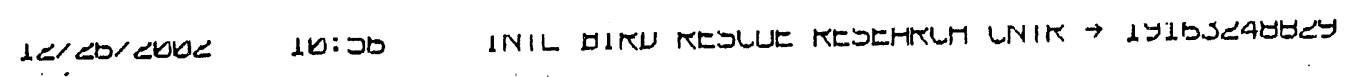

(19)

Beach Search Effort Log

Please record all beaches searched even if no birds are found.

(i)

Ais

Spill Name: Luckeobach

"Martin"

Date: $12 \cdot 24 \cdot 02$

Searchers: Melanie Markiw; Sim Haas

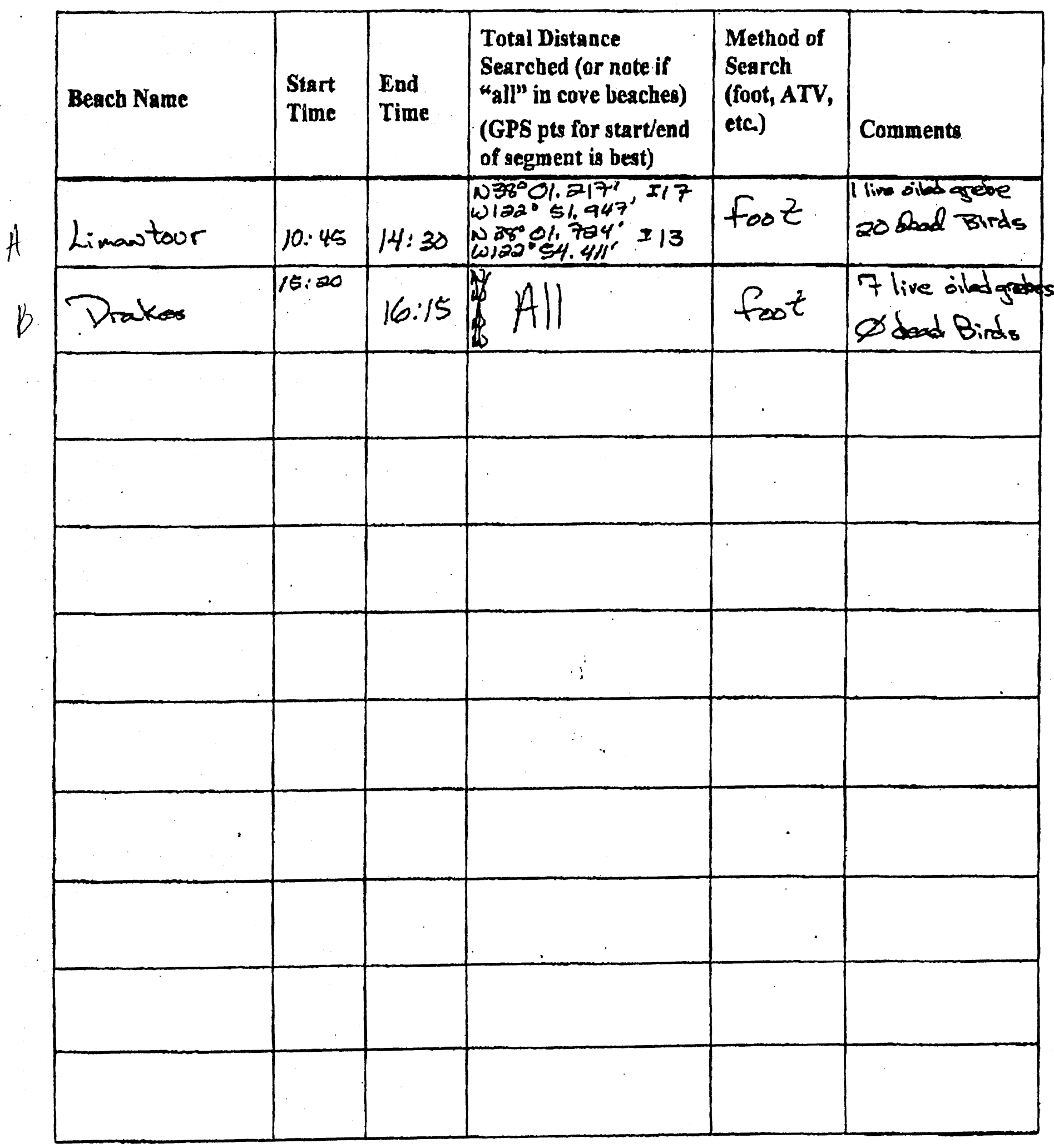




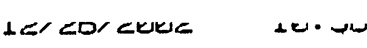

Dec. 2628

(20)

Sorrel Number:

Beach Search Effort Log

Please record all beaches searched even is mo birds' are found.

Spill Name: Eucken bach

Date: $12 / 24 / 02$

Searchers:S.me Allister /D. Goodfriend / m. Grieg

Note: Tine should include all tine spelt on live beach, oven when bncktrneking. North aud south endpoints should bo GPS pts. If that.

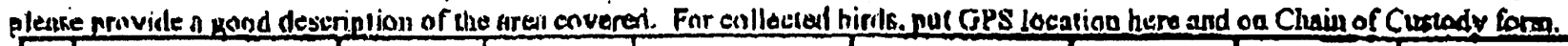

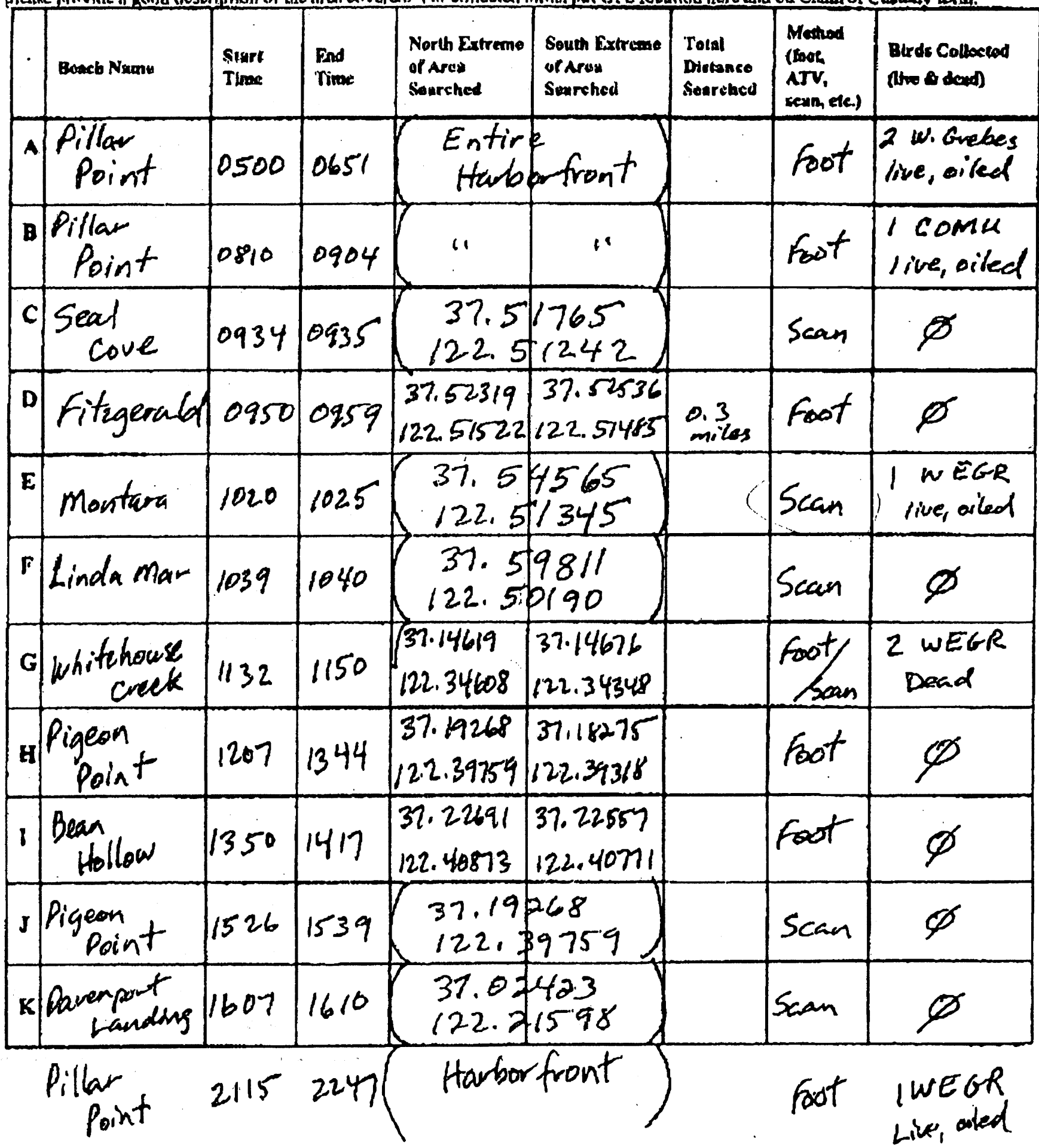




\section{Beach Search Effort Log}

Scarch Number: $\underset{\ldots}{2 B}$

Please record all beaches searched even if no birds are found.

Spill Name: Luckenbur.h

Date: 2At Deceimber oz

Searchers: Espinesa; Velez

Note: Time should include all time spent on the beach, even when backtracking. North and south endpoints should be GPS pts. If not, planse provide a good description of the area covered. For collected birds, pur GPS location here and on Chain of Custody forin.

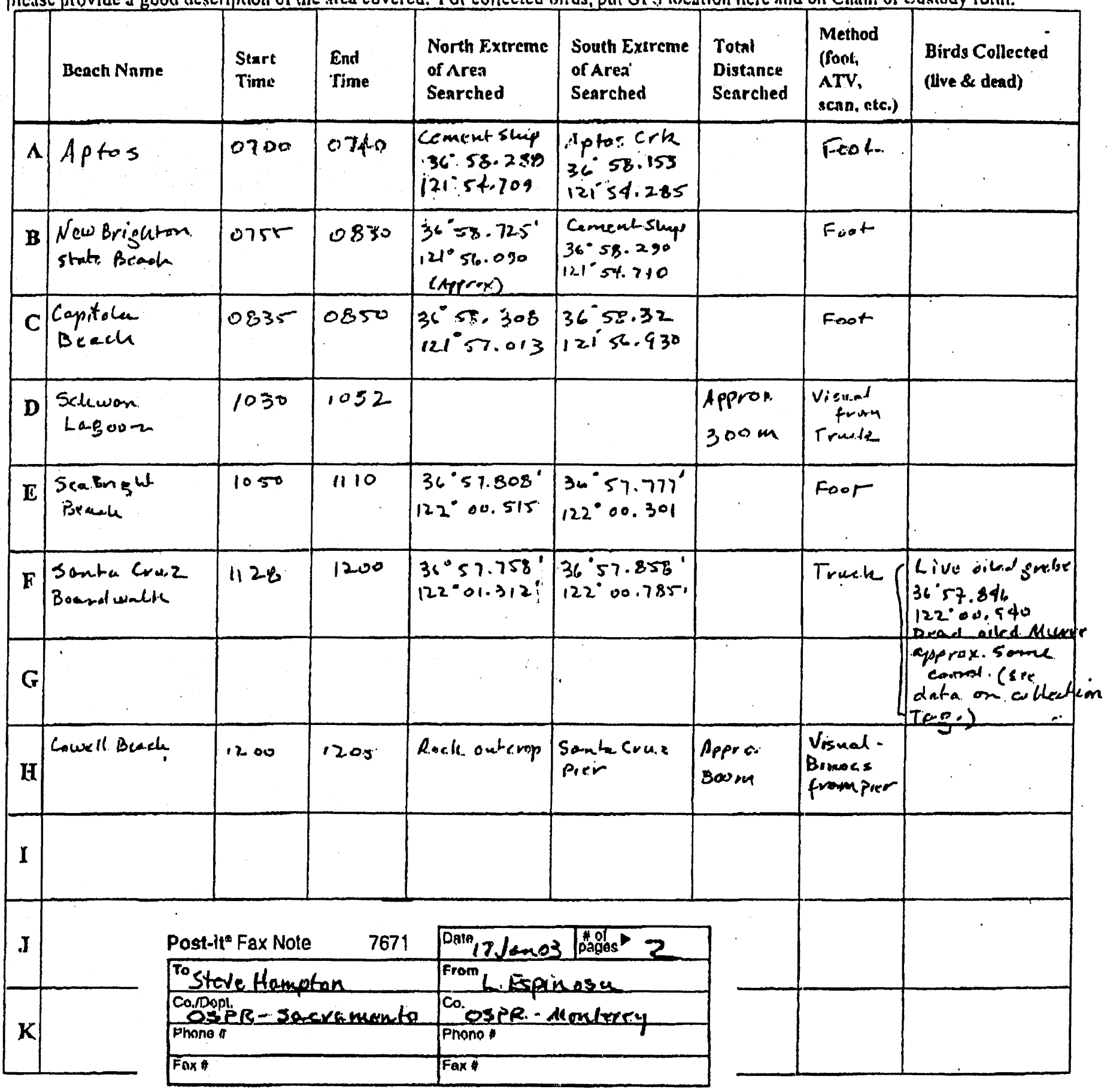


12/23/2002 14:14 INTL BIRD RESCIUE RESEARCH CNTR $\rightarrow 13153248829$

(22)

Search Number:

Beach Search Effort Log

Please record all beaches searched even if no birds are found.

Spill Name: Luckenbach

Date: $12 / 22 / 02$

Searchers: Sean McAllister w/Rebecca Dmytryk

Note. Time should include all time spent on the beach, even when backtracking. North and south endpoints should be GPS pts. If not, please provide a good description of che area covered. For collected birds. pul GPS location here and on Chain of Custody form.

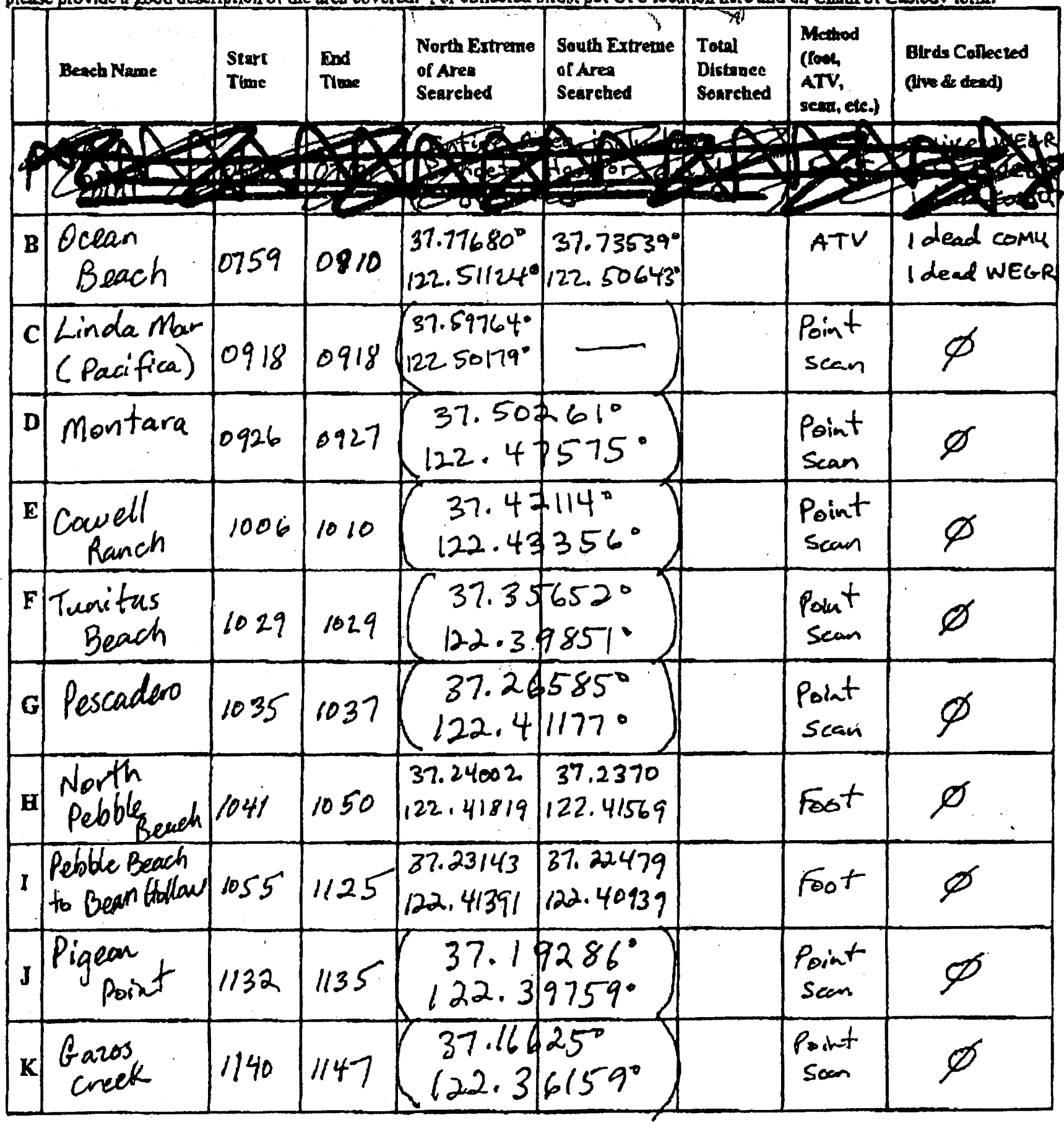

Pint 


\section{Beach Search Effort Log}

Search Number:

Please record all beaches seanched even if no birds are found.

Spill Name: Luckenbach

Date: $12 / 22 / 02$

Searchers: Sean McAllister, Rebeca Duytugk

Noto: Time should include all tine spent on the beach, even when backracking. Nortb and south ondpoint should be GPS pts. If not, please provide a pood description of the area coverod. Por colleciod birds, pur GPS location bere and on Chain of Custody form.

\begin{tabular}{|c|c|c|c|c|c|c|c|c|}
\hline & Beach Name & Start & $\begin{array}{l}\text { End } \\
\text { Tume }\end{array}$ & $\begin{array}{l}\text { North Extreme } \\
\text { of Ance } \\
\text { Searched. }\end{array}$ & $\begin{array}{l}\text { South Extreme } \\
\text { of Area } \\
\text { Searched }\end{array}$ & $\begin{array}{l}\text { Tolal } \\
\text { Distanase } \\
\text { Soarehod }\end{array}$ & $\begin{array}{l}\text { Metrod } \\
\text { (loor, } \\
\text { ATV, } \\
\text { sesn, ete.) }\end{array}$ & $\begin{array}{l}\text { Birdo Collected } \\
\text { (the se dead) }\end{array}$ \\
\hline $\boldsymbol{A}$ & $\begin{array}{l}\text { Pillar } \\
\text { Point } \\
\text { Harbor }\end{array}$ & $15: 05$ & $16: 39$ & $\begin{array}{l}\text { Included } \\
\text { iecess to } \mathrm{A} \\
\text { ramps on of }\end{array}$ & $\begin{array}{l}\text { west side } \\
\text { Astit and } \\
\text { outh side o }\end{array}$ & boat & foot & $\begin{array}{l}3 \text { WEGR } \\
\text { Live }\end{array}$ \\
\hline B & "1 & $21: 09$ & $22: 40$ & sam & $\begin{array}{l}e^{\prime a s} \text { "aye. } \\
\text { goye. }\end{array}$ & ) & Foot & $\begin{array}{c}3 \text { WELR } \\
\text { Live }\end{array}$ \\
\hline $\mathbf{C}$ & & & & & & & & \\
\hline D & & & & & & & & \\
\hline $\mathbf{E}$ & & & & & & & & \\
\hline $\mathbf{F}$ & & & & $\because$ & & & & \\
\hline $\mathbf{G}$ & & & & •. & & & & \\
\hline $\mathbf{H}$ & - & & & & & & & \\
\hline I & & & & & & & & \\
\hline $\mathbf{J}$ & & & & & & & & \\
\hline $\mathbf{K}$ & & & & & & & & \\
\hline
\end{tabular}




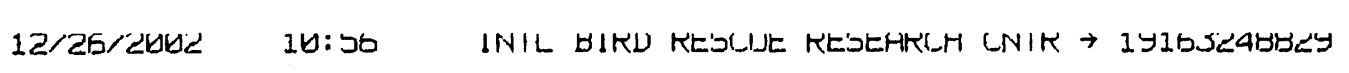

(24)

Beach Search Effort Log

Search Number:

Please record all beaches searched even if no birds are found.

Spill Name: Luckarboch

Date: $12 / 22 / 02$

searchers: Williamson/ Goodtmicad

Note: Time should irechde all time spent on the beach, even when backtracking. North and south endpoints should be GPS pts. If not. please provide a good description of the area covered. For collected birds, put GPS location hare and on Chain of Custody form.

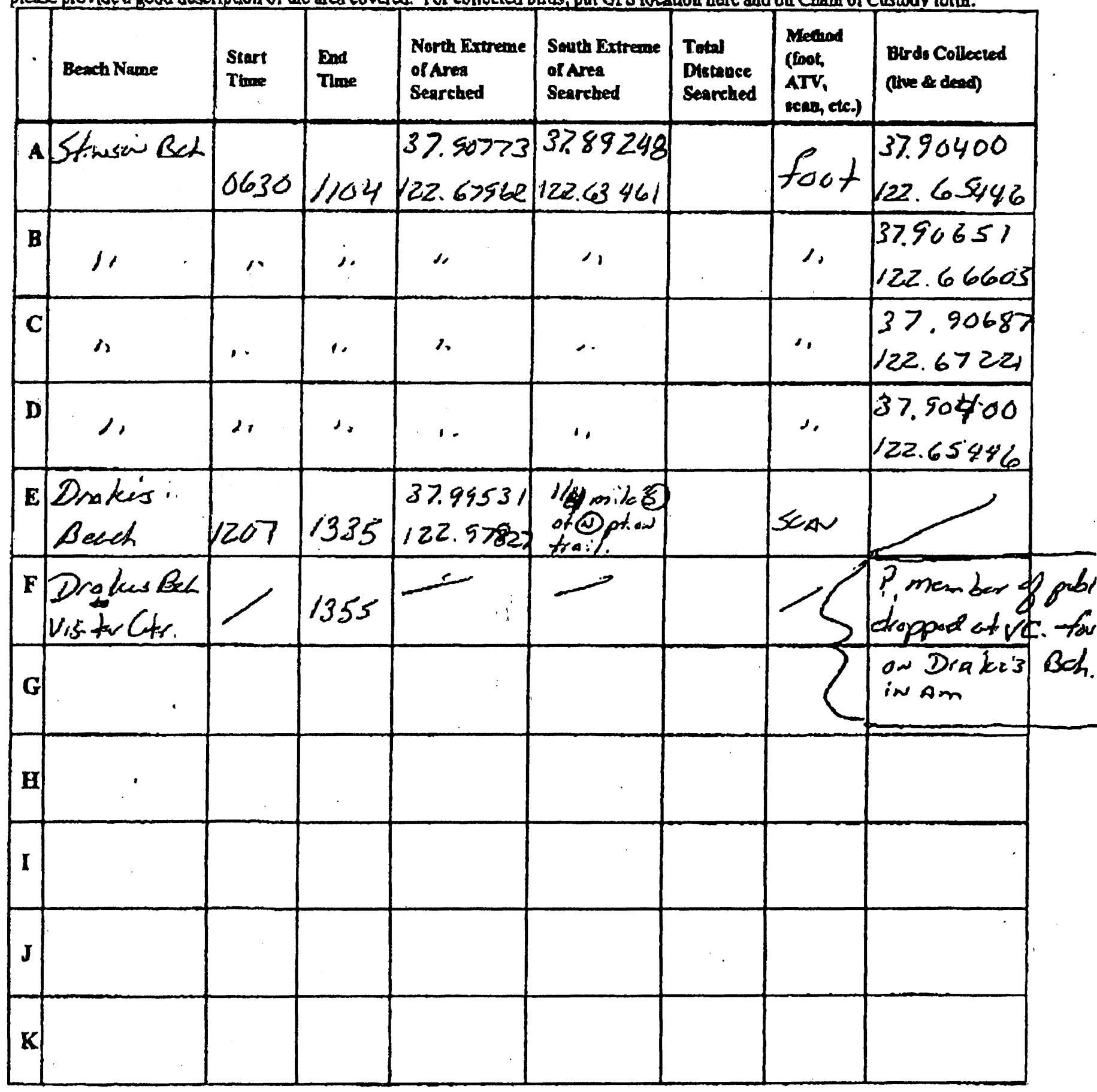


“. Beach Search Effort Log

Please record all beaches searched even if no birds are found.

Spill Name: LUC Saret

Date: $12 / 2-2: 32$

Searchers: DPQLEF; I HARDWiCK

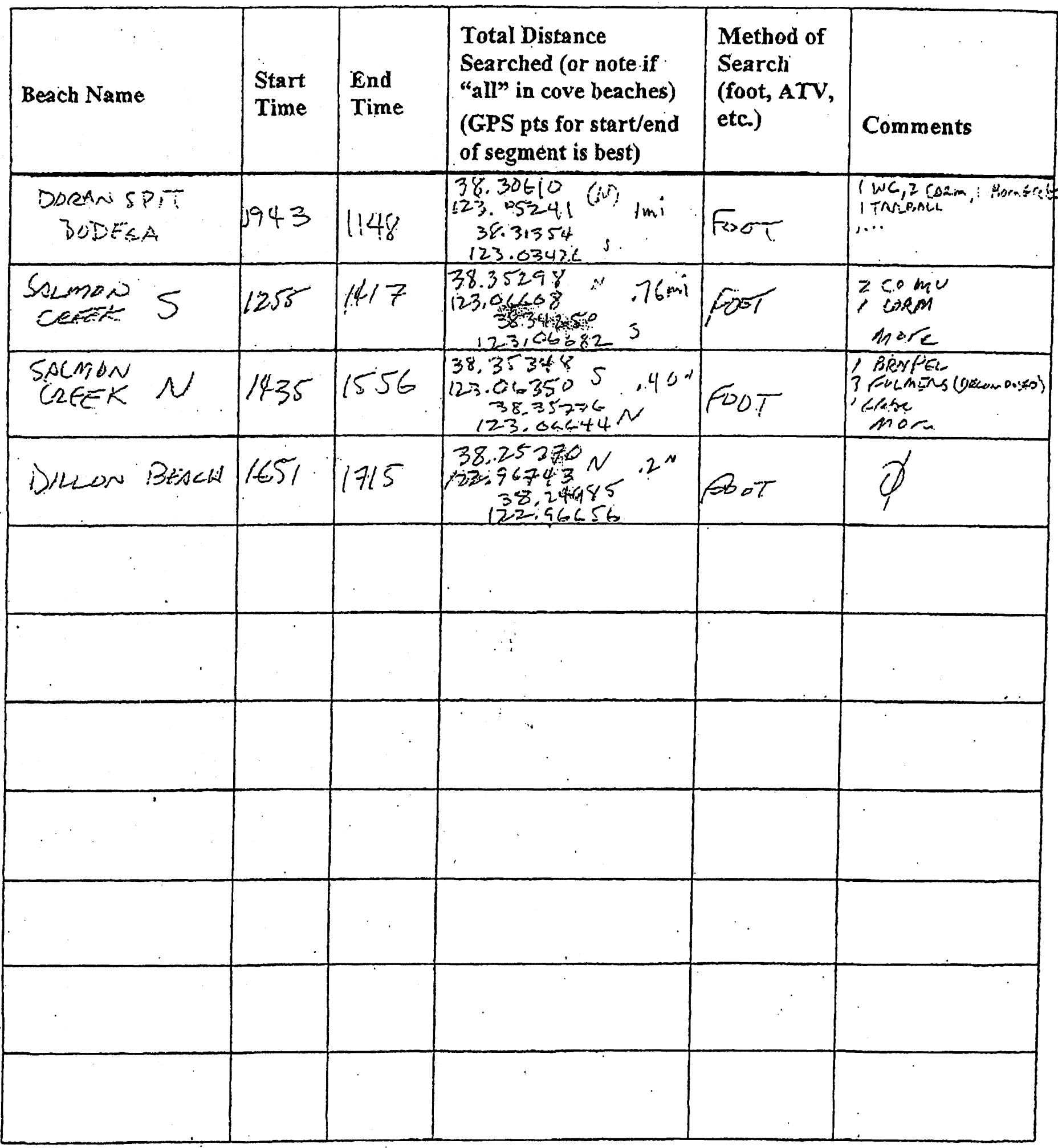


$12 / 23 / 2002 \quad 14: 14$ INTI BIRD RESCUE RESEARCH INTR $\rightarrow 19163248829$

(26)

Bryant Austin - Search Effort Log 6-21-02.000

Search Number:

Beach Search Effort biog:

Please record all beaches searched even if no birds are found.

Spill Name: Luckeubada

$$
\text { Date: } 12<2(-0)
$$

Searchers: Saygiacomo/Griehl

Note: Time should include all time spent on the beach, even when backtracking. North and south endpoint e should be GPS pes. If not, please provide s rood description of the area covered. For collected birds. pul GPS location here and on Chain of Custody form.

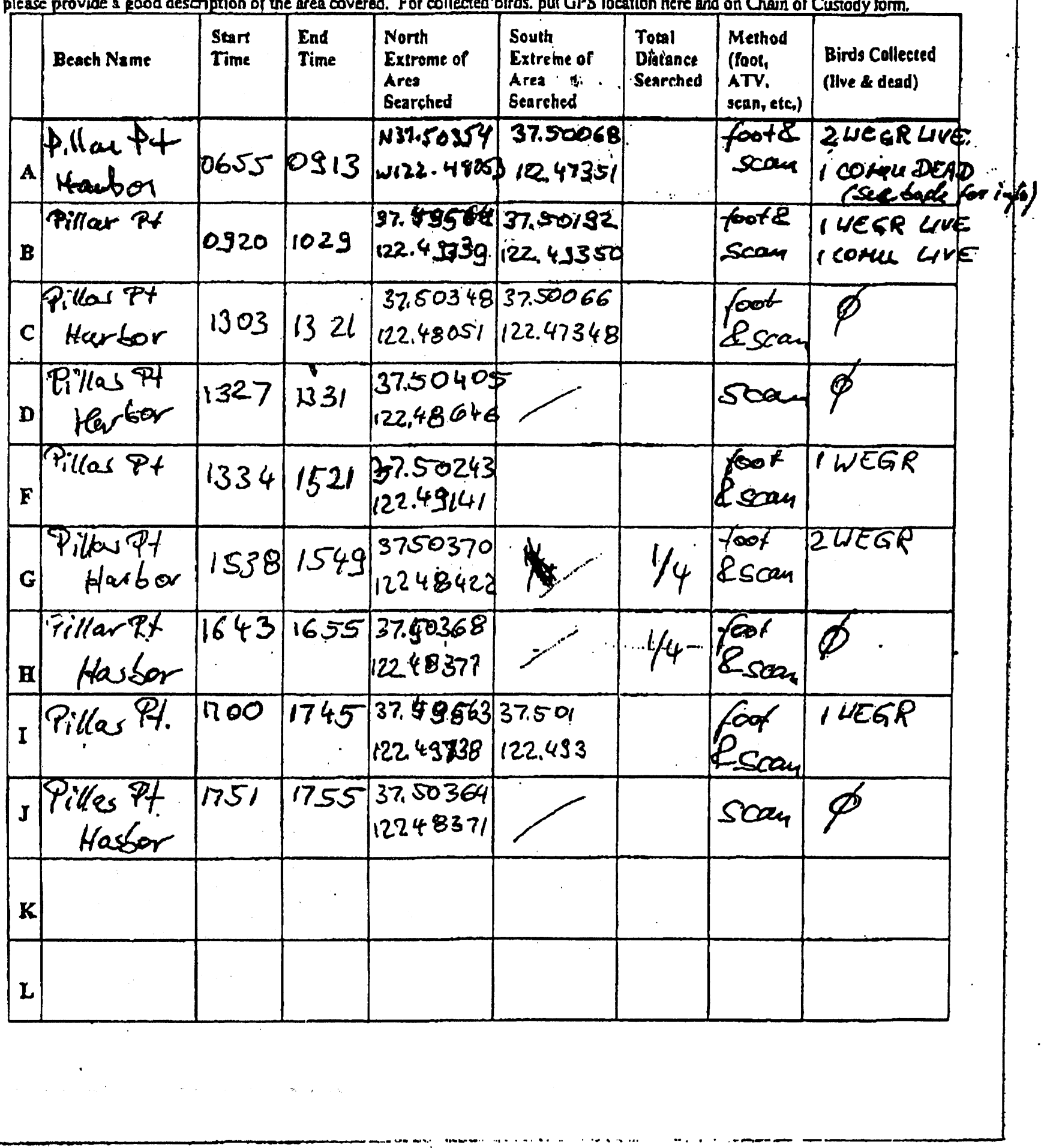




\section{Beach Search Effort Log}

Please record all beaches searched even if no birds are found.

$$
\mu_{c}
$$

Seanch Number:

Spill Name: Lucken bach

Date: $12 / 2,02$

searchers: Sesm McAllister, Don Ballard

Note: Time stould inchude all tine speat on the beach, ovea when backtrackiug. North and solth endpoiats should be GPS pts. If not, please provido a pood description of the srea covered. For collested binds, pur GPS location here and on Chain of Custody form.

\begin{tabular}{|c|c|c|c|c|c|c|c|c|}
\hline & Bench Nasure & $\begin{array}{l}\text { Start } \\
\text { TTure }\end{array}$ & $\begin{array}{l}\text { Dod } \\
\text { Tulue }\end{array}$ & $\begin{array}{l}\text { North Estreme } \\
\text { of Arca } \\
\text { Soarchied }\end{array}$ & $\begin{array}{l}\text { Sorth Extreme } \\
\text { of Area } \\
\text { Searched }\end{array}$ & $\begin{array}{l}\text { Total } \\
\text { Diotunce } \\
\text { Searched }\end{array}$ & $\begin{array}{l}\text { Method } \\
\text { (6oos } \\
\text { ATV, } \\
\text { nceno, ete) }\end{array}$ & $\begin{array}{l}\text { Btrds Collocted } \\
\text { (twe \& dead) }\end{array}$ \\
\hline$A$ & $\begin{array}{l}\text { Crissy } \\
\text { field }\end{array}$ & 0700 & 0750 & & & & foot & \\
\hline B & $\begin{array}{l}\text { Ocean } \\
\text { Beach }\end{array}$ & 0800 & 0900 & $\begin{array}{l}37.77684^{\circ} \\
122.51136^{\circ}\end{array}$ & $\begin{array}{l}37.76270^{\circ} \\
122.51127^{\circ}\end{array}$ & $\begin{array}{l}\text { w3.2 } \\
\text { miles }\end{array}$ & ATV', & $\left.\begin{array}{l}\text { (seeyes. } \\
\text { paye } 2\end{array}\right)$ \\
\hline C & $\begin{array}{l}\text { Sharp } \\
\text { Park }\end{array}$ & 0824 & 0836 & $\begin{array}{l}37.62708^{\circ} \\
122.49353^{\circ}\end{array}$ & $\begin{array}{l}37.62992^{\circ} \\
122.49310\end{array}$ & & foot & \\
\hline D & Rockaway & 0991 & 0992 & & & & & \\
\hline $\mathbf{E}$ & $\begin{array}{l}\text { Linda Mar } \\
\text { (Pacifica) }\end{array}$ & 0941 & 0943 & $\begin{array}{r}37.59 \\
122.50 \\
\end{array}$ & $\begin{array}{l}764^{\circ} \\
179^{\circ}\end{array}$ & & $\begin{array}{l}\text { Point } \\
\text { Sean }\end{array}$ & \\
\hline F & $\begin{array}{l}\text { Grey whale } \\
\text { co ve } \\
\text { CMcNee Ranch) }\end{array}$ & 1004 & 1015 & $\begin{array}{l}37.56573^{\circ} \\
122,51319^{\circ}\end{array}$ & $\begin{array}{l}37.563910 \\
122.51260^{\circ}\end{array}$ & & Foot & \\
\hline $\mathbf{G}$ & $\begin{array}{l}\text { Pedro Point } \\
\text { overlook }\end{array}$ & 0949 & 0950 & $\begin{array}{r}37.59 \\
122.5\end{array}$ & $\left(\begin{array}{l}659^{\circ} \\
0836^{\circ}\end{array}\right)$ & & $\begin{array}{l}\text { Point } \\
\text { Scan }\end{array}$ & \\
\hline $\mathbf{H}$ & $\begin{array}{l}\text { Montara } \\
\text { Beach }\end{array}$ & 1037 & 1038 & $\begin{array}{r}37.5 \\
122.5 \\
\end{array}$ & $\begin{array}{l}5268^{\circ} \\
1183^{\circ}\end{array}$ & & $\begin{array}{l}\text { Point } \\
\text { Scan }\end{array}$ & \\
\hline I & Pillar & 1237 & 1511 & $\begin{array}{l}\text { Entire Ant } \\
\text { includely } \\
\text { boat rang }\end{array}$ & $\begin{array}{l}\text { a seanched } \\
\text { west side } \\
\text { p, harbor, }\end{array}$ & $\begin{array}{l}\text { iaccess, } \\
\text { jetties }\end{array}$ & Foot & $\begin{array}{c}\text { yes. } \\
\text { see page } 2\end{array}$ \\
\hline J & $\begin{array}{l}\text { Half moon } \\
\text { Bay State } \\
\text { Beach }\end{array}$ & 1612 & 1649 & $\begin{array}{l}37.49325^{\circ} \\
122.45895^{\circ}\end{array}$ & $\begin{array}{l}37.44181^{\circ} \\
122.44380^{\circ}\end{array}$ & & $\begin{array}{l}\text { AT, } \\
\text { foot }\end{array}$ & $\begin{array}{c}\text { Yes. } \\
\text { seepege 2) }\end{array}$ \\
\hline & & & & & & & & \\
\hline
\end{tabular}


INTL BIRD RESCUE RESEARCH CNTR $\rightarrow 19163248829$

(28)

Luckenbach

Page $20 .+:$

Sean McAllister w/ Don Ballard

$12 / 21 / 02$

B. Ocean Beach 0800-0900

1 Live WEGR $N 37.77684^{\circ} / w 122.50987^{\circ}$

1 Dead comu N $37.76390^{\circ} / w_{122.51030^{\circ}}$

1 Dead comu N37. $75597^{\circ} / W / 22.50927^{\circ}$

2 Dead comu N $37.747290^{\circ} / W 122.50767^{\circ}$

I. Pillar Point. $1237-1511$

$$
\begin{aligned}
& 1 \text { LVE WEGR N } 37.50261^{\circ} \mathrm{I} W 122.47575^{\circ} \\
& \text { I Live WEGR N } 37.50332^{\circ} / W 122.47770^{\circ} \\
& \text { I LIVE WEGR N37. } 50189^{\circ} / W 122.49333^{\circ}
\end{aligned}
$$

J. Half moon Bay State Beaches

1 Dead WEGR $37.46519^{\circ} / w 122.44498^{\circ}$

1. Dead comu $37.46049^{\circ}$ w $122.44445^{\circ}$

1 Dead comu 37. $44965^{\circ} / w 122.44381^{\circ}$

1 Dead comu 37. $47336^{\circ} /$ w $122.44663^{\circ}$ 
$12 / 23 / 2002 \quad 14: 14$ INTI BIRD RESCUE RESEARCH UNIT $\rightarrow$ 1710دC400CD

(29)

Beach Search Effort Log

Please record all beaches searched even if no blinds are found.

Search Number.

$$
213
$$

spill Name: Lucke-bach

Date: $12 / 21 / 62$

Searchers: Deirdre Goodfined D rue Adkins

Note: Time should include all time spear on the beach, even when back racking. North and south endpoints should be GPS pts. If not. please provide a good description of the area covered. For collected birds. put GPS location here and on Chain of Custody form.

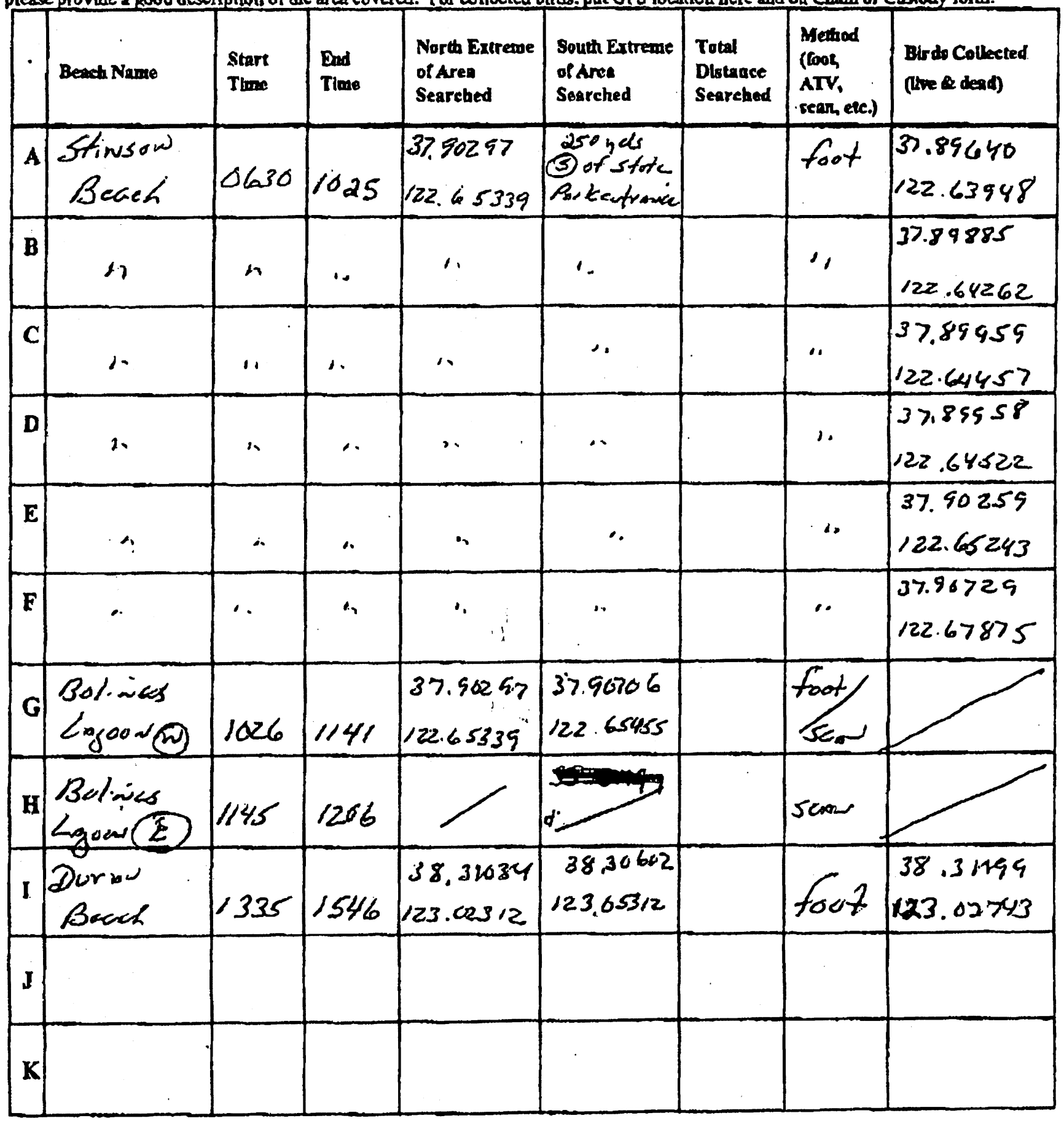


LE

(30)

Bryant Austin - Search Effort Log 6-21-02 doc

Search Number.

Beach Search Effort Log

Please record all beaches searched even if no birds are, found.

Spill Name: Luchembach

Date: $12 / 20 / 02$

Searchers: Sanglacomo/Gigeh

Note: Time should include all time spent on the beach, even when backtracking. North and south endpoint should be GP5 pes. If not. please provide a pood description of the area covered. For collected birds, put GPS location here and on Chain or Custody form.

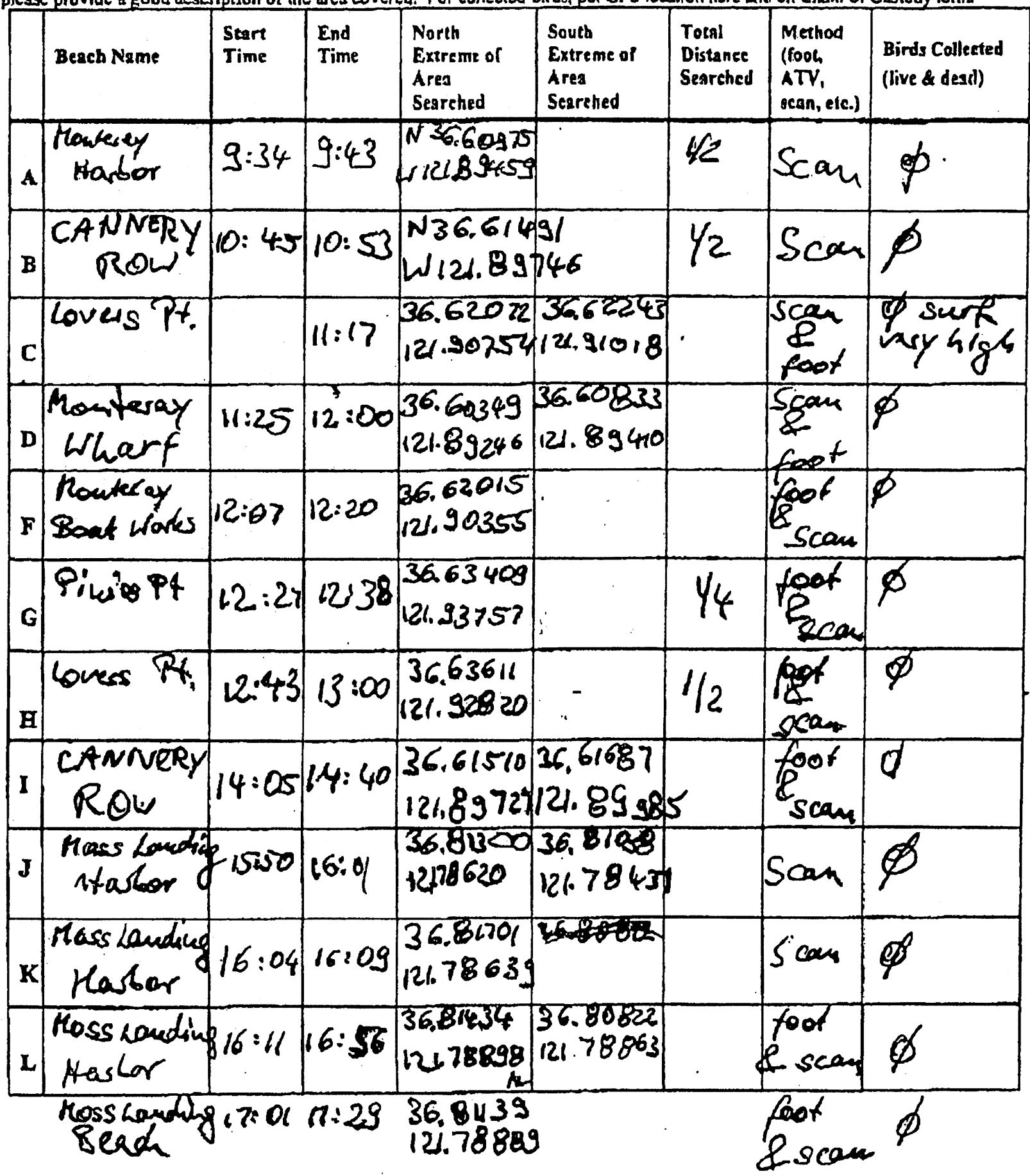


$1</<1<<$ <ש

pecten

*... see over for notes

Search Number:

Beach Search Effort Log

Please record all beaches searched even if no bis cs are found.

Spill Name: Lu k ken bach

Date: $12 / 20 / 02$

Searchers: Sean McAllistor, Don Ballard

Note: Time should include all time spent on the beach, even when backtracking. North and south endpoints should be GPS pes. II not. please provide a good description of the area covered. For collected birds. put GPS location here and on Chain of Custody form

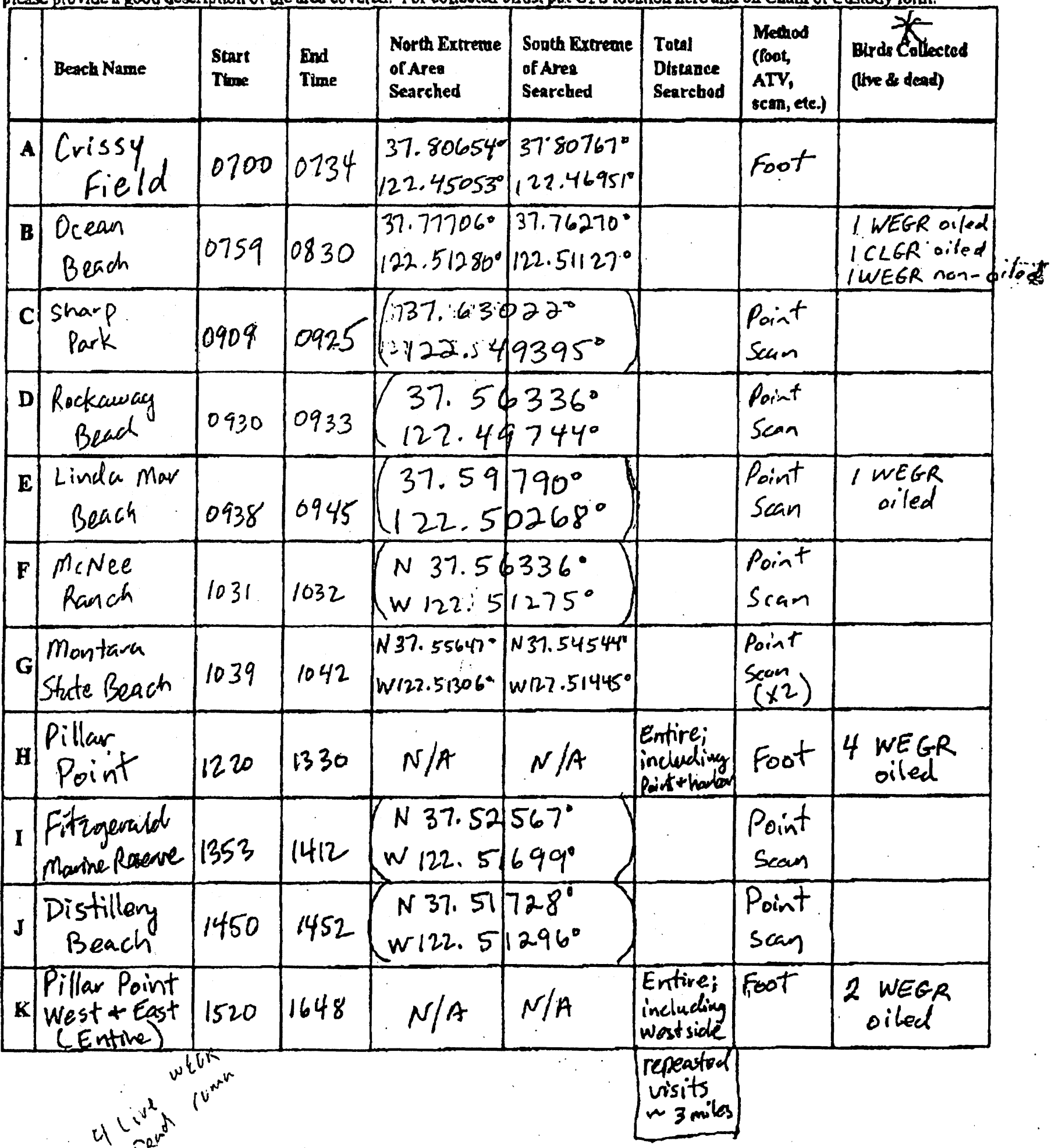


Bryant Austin - Search Effort_Log_6-21-02.00c

$$
707-496 \cdot 8790
$$

Search Number:

Beach Search Effort Log

Please record all beaches searched even if no birds are found.

Spill Name: Lusctembach

Searchers: tangeacomo/6riéhl

$$
\text { Date: } 12-19-01
$$

Note: Time should include all time spent on the beach, even when backtracking. North and south endpoints should be GPS pts. If not, please provide a good description of the area covered. For collected birds. pus GPS location here and on Chain of Custody form.

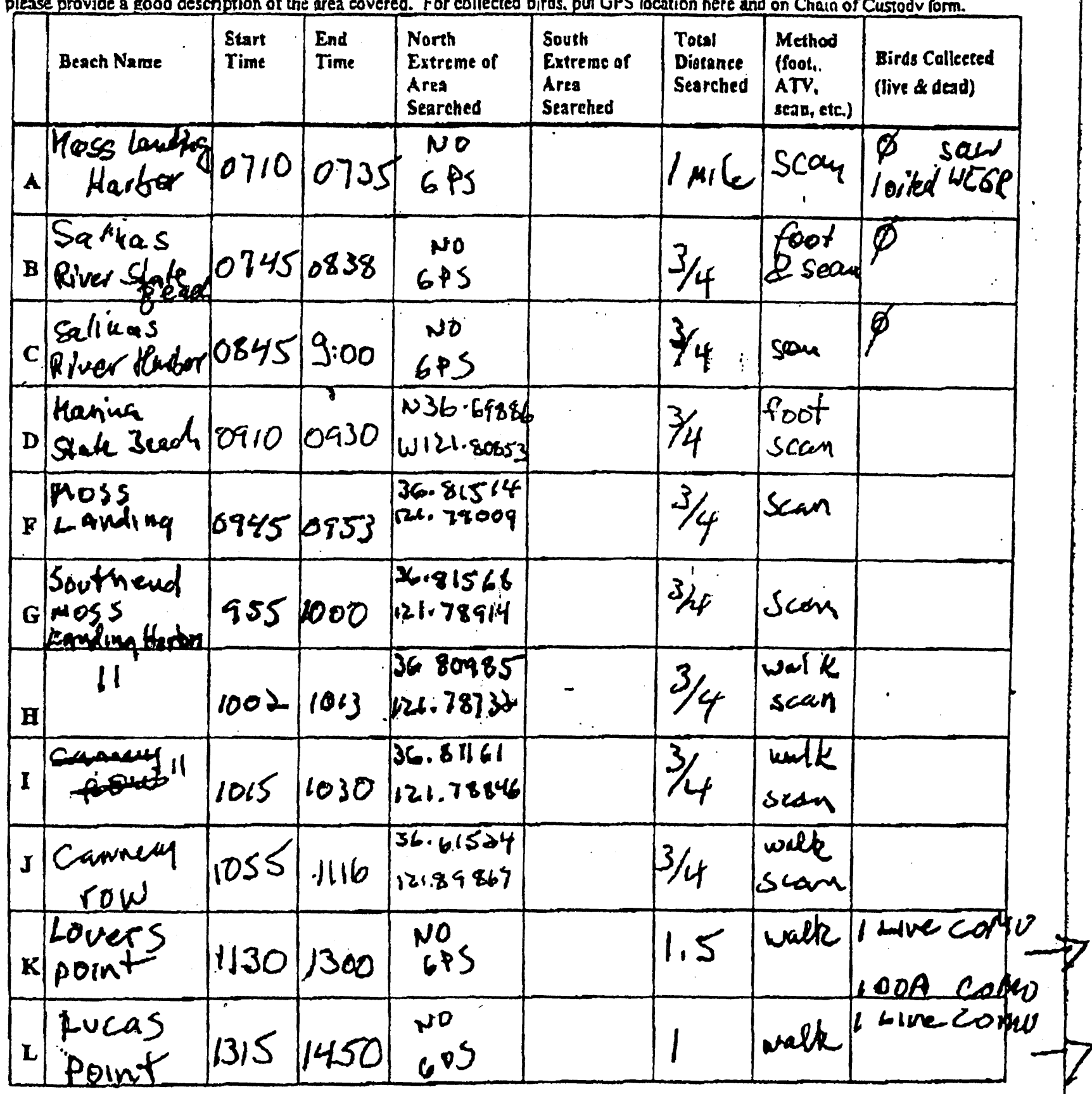


- $20 / 2802 \quad 15: 40$ INTI BIRD RESCUE RESEARCH CNTR $\rightarrow 19163248829$

(33)

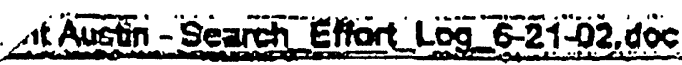

Sears Number:

Beach Search Effort Log.

Please record all beaches searched even if no birds ore found.

Spill Name: Luclese bach

$$
\text { Date: } 12-19-02
$$

Serchers:-Weady Sandra comp/Monja brie/

Note: Time should induce all time spent on the beach, even when backtracking. North and south endpoints should be GPS pis. If not. please provide s good description of the urea covered. For collected birds. put OPS location here and on Chain of Custody form.

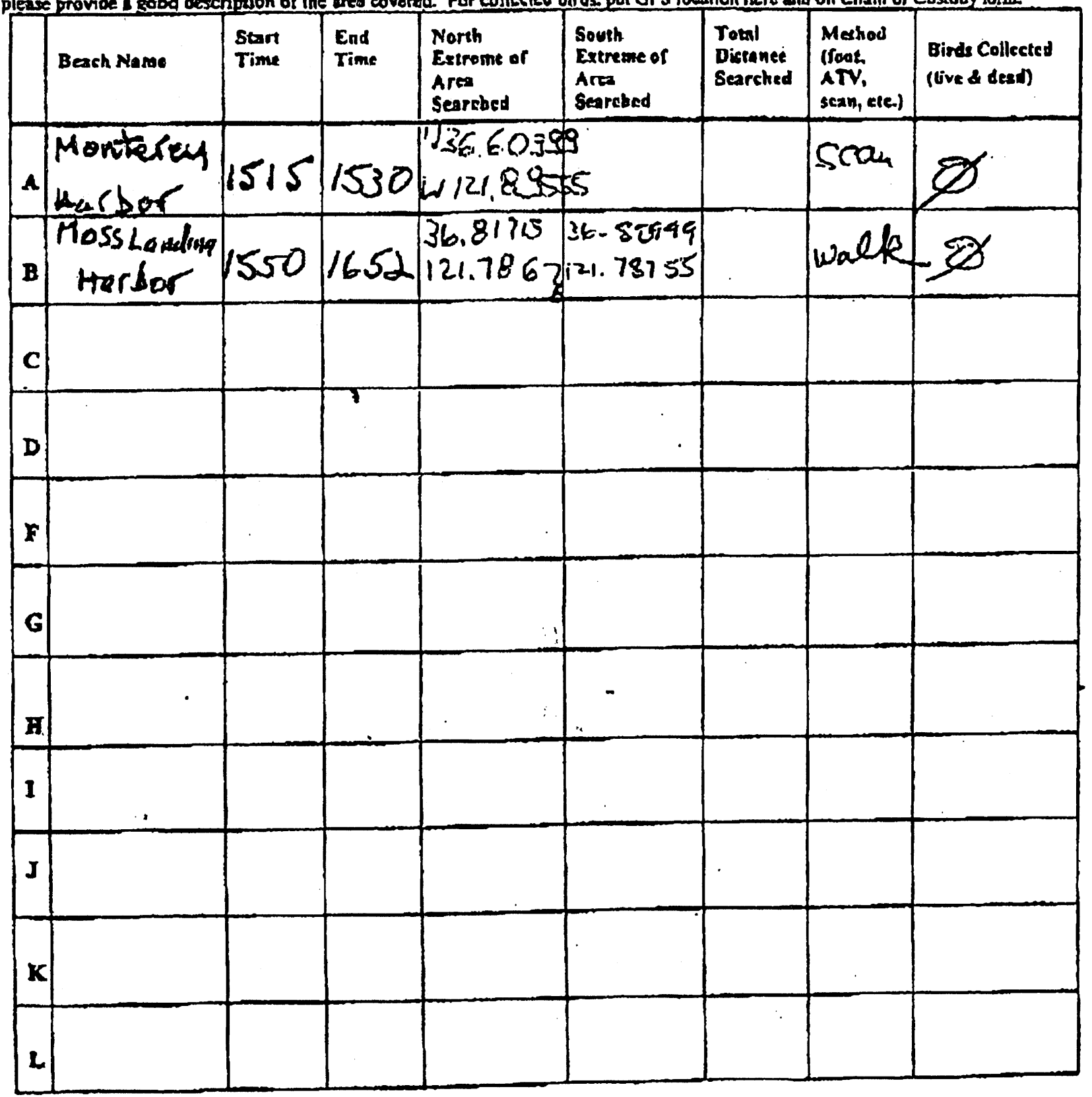

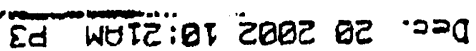

QDBEEEEISA : 'ON XU A

13XINOW HDELZIE : TOY 
Scanch Number.

\section{Beach Search Effort Log}

Please record all beaches searched even if no birds are found.

spill Name: Lucken bach

Date: $12 / 15 / 02$

Searchers: Bruec Atkins

Note Time should include all timo spent on the beach, even when backonacking. North and south endpoints should be GPS pts. If not, please provide a rood description of the area covered for collected birds, pur GPS location here and on Chsin of Cuscody lomen.

\begin{tabular}{|c|c|c|c|c|c|c|c|c|}
\hline - & Beach Namc & $\begin{array}{l}\text { Start } \\
\text { Thme }\end{array}$ & $\begin{array}{l}\text { End } \\
\text { Tition }\end{array}$ & $\begin{array}{l}\text { North Eztrome } \\
\text { of Area } \\
\text { Searched }\end{array}$ & $\begin{array}{l}\text { Souch Exrreme } \\
\text { of Area } \\
\text { Searched }\end{array}$ & $\begin{array}{l}\text { Total } \\
\text { Distuvee } \\
\text { Searehed }\end{array}$ & $\begin{array}{l}\text { Method } \\
\text { (100t, } \\
\text { ATV, } \\
\text { seas, ete) }\end{array}$ & $\begin{array}{l}\text { Birds Collocted } \\
\text { (hive \& dead) }\end{array}$ \\
\hline $\mathbf{A}$ & $\begin{array}{l}\text { Scott } \\
\text { Cruck }\end{array}$ & $\begin{array}{l}1543 \\
150\end{array}$ & 1556 & $\begin{array}{l}37.6398 \\
122.226\end{array}$ & $\begin{array}{l}3 \\
85\end{array}$ & & $5 \cos 2$ & \\
\hline B & $\begin{array}{l}\text { Pisean } \\
\text { Point }\end{array}$ & $\begin{array}{l}1617 \\
160\end{array}$ & 1640 & $\begin{array}{l}37.19251 \\
122.39648\end{array}$ & $\begin{array}{l}37.18537 \\
122.39454\end{array}$ & & send & \\
\hline C & & & & & & & & \\
\hline D & & & & & & & & \\
\hline $\mathbf{E}$ & & & & & & & & \\
\hline $\mathbf{F}$ & & & & & & & & \\
\hline $\mathbf{G}$ & & & & & & & & \\
\hline $\mathbf{H}$ & - & & & & & & & \\
\hline I & & & & & & & & \\
\hline J & & & & & & & & \\
\hline $\mathbf{K}$ & & & & & & & & \\
\hline
\end{tabular}




\section{Beach Search Effort Log}

Please record all beaches searched even if no birds are found.

\section{$2 B$}

spill Name: Luckew bach

Date: $12 / 15 / 02$

Sexrchers: Deirdre Goodtherel

Note Time should include all lime speat on the beach, oven whea beckuracking. North and south endpoiats should be GPS pts. If wot, please provide a good description of the area covered. For collected binds, pur GPS location here and on Chain of Cossoody form.

\begin{tabular}{|c|c|c|c|c|c|c|c|c|}
\hline & Beach Name & $\begin{array}{l}\text { Start } \\
\text { Trune }\end{array}$ & $\begin{array}{l}\text { Fnd } \\
\text { Tlue }\end{array}$ & $\begin{array}{l}\text { Norch Ertreane } \\
\text { of Area } \\
\text { Searchod }\end{array}$ & $\begin{array}{l}\text { Sophin Fustreme } \\
\text { of Aver } \\
\text { Searehed }\end{array}$ & $\begin{array}{l}\text { Tocal } \\
\text { Distance } \\
\text { Searethed }\end{array}$ & $\begin{array}{l}\text { stethod } \\
\text { (1000, } \\
\text { ATV, } \\
\text { reenm, ete.). }\end{array}$ & $\begin{array}{l}\text { Btrods Collocted } \\
\text { (tho \&e diead) }\end{array}$ \\
\hline $\mathbf{A}$ & $\begin{array}{l}\text { Waddeel } \\
\text { Creetk }\end{array}$ & 1546 & 1603 & $\begin{array}{l}37.09697 \\
122.27856\end{array}$ & $\begin{array}{l}150 \text { hadis } \\
\text { south of } \\
00 \text { pt }\end{array}$ & & $\operatorname{sen} 0$ & \\
\hline B & $\begin{array}{l}\text { Bean } \\
\text { Hollow }\end{array}$ & 1621 & 1632 & $\begin{array}{l}37.22616 \\
122.408+22\end{array}$ & $\begin{array}{l}37.2256 \\
122.46777\end{array}$ & & $5 \cos \alpha$ & \\
\hline $\mathbf{C}$ & & & & & & & & \\
\hline D & & & & & & & & \\
\hline $\mathbf{E}$ & & & & & & & & \\
\hline $\mathbf{F}$ & & & & I & & & & \\
\hline G & & & & & & & & \\
\hline $\mathbf{E}$ & - & & & & & & & \\
\hline I & & & & & & & & \\
\hline J & & & & & & & & \\
\hline $\mathbf{K}$ & & & & & & & & \\
\hline
\end{tabular}




\section{Beach Search Effort Log}

Please record all beaches searched even if no birds are found.

Scarch Number.

Spill Name: Luckenbach Deirdre A. Goodfriend

Date: $12 / 19 / 02$

Searchers: Bruce Atkins

Note: Time should include all time speut on the beach, even when backtracking. North and south endpoints should be GPS pta. If not. please provide a good description of the area covered. For collected birds. put GPS lacation here and on Chain of Custody torm.

\begin{tabular}{|c|c|c|c|c|c|c|c|c|}
\hline . & Beach Name & $\begin{array}{l}\text { Stare } \\
\text { Time }\end{array}$ & $\begin{array}{l}\text { End } \\
\text { Tiroe }\end{array}$ & \begin{tabular}{|l|} 
North Extreane \\
of Area \\
Searehed
\end{tabular} & $\begin{array}{l}\text { South bixtreme } \\
\text { of Area } \\
\text { Searched }\end{array}$ & $\begin{array}{l}\text { Total } \\
\text { Discance } \\
\text { Searcticed }\end{array}$ & $\begin{array}{l}\text { Metbed } \\
\text { (foot, } \\
\text { ATV, } \\
\text { sean, ete) }\end{array}$ & $\begin{array}{l}\text { Birds Collected } \\
\text { (the \& doad) }\end{array}$ \\
\hline $\mathbf{A}$ & $\begin{array}{l}P_{i} \\
P_{0}\end{array}$ & 0630 & 0944 & & & & foot & $\begin{array}{l}37.49627 \\
122.45423\end{array}$ \\
\hline B & 11 & 1. & $\cdot$ & & & & (1) & $\begin{array}{l}37.49582 \\
122.49426\end{array}$ \\
\hline C & 11 & .. & .. & & & & +1 & $\begin{array}{l}37.49584 \\
122.45526\end{array}$ \\
\hline D & 11 & 1 & 1. & & & & 1) & $\begin{array}{l}37.45574 \\
122.49553\end{array}$ \\
\hline $\mathbf{E}$ & $\begin{array}{l}\text { Miremar } \\
\text { Beach }\end{array}$ & 10955 & 1002 & $\begin{array}{l}\text { Viewed } \\
\text { fuen } \\
\text { aceess }\end{array}$ & $\begin{array}{l}\text { vicumed } \\
\text { from } \\
\text { aecioss }\end{array}$ & & scons & \\
\hline $\mathbf{F}$ & $\begin{array}{l}\text { Souta } \\
\text { Crue } \\
\text { Bondiondk }\end{array}$ & 1220 & 1310 & $\begin{array}{r}36.56117 \\
122.0239\end{array}$ & $\begin{array}{c}d s \\
\text { Nat } \\
\end{array}$ & & foot & $\begin{array}{l}36.96332 \\
122.62138\end{array}$ \\
\hline $\mathbf{G}$ & 11 & 1. & 1. & 1, & $\therefore$ & & 1 & $\begin{array}{l}36.96117 \\
122.02355\end{array}$ \\
\hline $\mathbf{H}$ & $H^{\prime}$ & 10 & $\because$ & $\cdots$ & 10 & & $\cdots$ & $\begin{array}{l}36.96111 \\
122.02398\end{array}$ \\
\hline I & $\begin{array}{l}\text { Natural } \\
\text { Bridjes }\end{array}$ & 1350 & 1425 & & & & faot & \\
\hline $\mathbf{J}$ & $\begin{array}{l}\text { Woldm } \\
\text { Ravah }\end{array}$ & 1445 & 1530 & & & & fout & $\begin{array}{l}\text { Live canu } \\
\text { Ne GRS }\end{array}$ \\
\hline $\mathbf{K}$ & 1 & 小 & $A$ & $r$ & 1. & & & $\begin{array}{l}\text { Dead Comv } \\
\text { No GPS }\end{array}$ \\
\hline & Orertouk & 1100 & 1106 & \multicolumn{3}{|c|}{$\begin{array}{c}37.45506 \\
(22.44221\end{array}$} & $5(0)$ & \\
\hline
\end{tabular}




\section{Beach Search Effort Log}

Search Number:

Please record all beaches searched even if no birds are found.

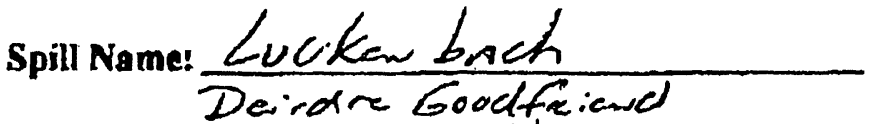

Date: $12 / 15 / 02$

Searchers: Bruce $A+k i w s$

Note. Time should include all time spent on the beach, even when backtracking. North and south endpoints should be GPS pts. If not. please nrovide a guod description of the srea covered. For collevied birds. pur GPS location bere and on Chain of Custody farm.

\begin{tabular}{|c|c|c|c|c|c|c|c|c|}
\hline v & Beach Name & $\begin{array}{l}\text { Start } \\
\text { Throce }\end{array}$ & $\begin{array}{l}\text { Fond } \\
\text { Tione }\end{array}$ & $\begin{array}{l}\text { North Extreme } \\
\text { of Area } \\
\text { Searched }\end{array}$ & $\begin{array}{l}\text { South Extrame } \\
\text { of Area } \\
\text { Searched }\end{array}$ & $\begin{array}{l}\text { Total } \\
\text { Dlatance } \\
\text { Searched }\end{array}$ & $\begin{array}{l}\text { Method } \\
\text { (cooh, } \\
\text { ATV, } \\
\text { scan, ete) }\end{array}$ & $\begin{array}{l}\text { Burds Collocted } \\
\text { (the \& dead) }\end{array}$ \\
\hline $\mathbf{A}$ & $\begin{array}{l}\text { San } \\
\text { Grzedid }\end{array}$ & 1655 & $17 / 5$ & $\begin{array}{l}\text { Midpoin } \\
37.3000 \\
122.404\end{array}$ & $\begin{array}{l}4: \\
37\end{array}$ & 200 yds & foot & \\
\hline B & & & & & & & & \\
\hline C & & & & & & & & \\
\hline D & & & & & & & & \\
\hline $\mathbf{E}$ & & & & & & & & \\
\hline $\mathbf{F}$ & & & & $\because$ & & & & \\
\hline $\mathbf{G}$ & & & & $\because r$ & & & & \\
\hline $\mathbf{H}$ & & & & & & & & \\
\hline I & & & & & & & & \\
\hline $\mathbf{J}$ & & & & & & & & \\
\hline $\mathbf{K}$ & & & & & & & & \\
\hline
\end{tabular}


$1</<U / \angle U V<\quad 10: 4 \pi$

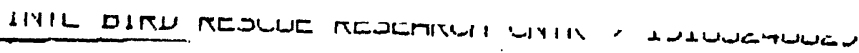

(38)

Beach Search Effort Log

Search Number:

Please record all beaches searched even if no birds are found.

Spill Name: Lukenbach

Date: $12-19-02$

Searchers: Sean McAllister, Den Ballard

Note. Tine should include all time spent oo the beach, even when backtracking. North and south endpoints should be GPS pes. If not, please provide a good description of the area covered. For collected birds. pus GPS location here and on Chain of Cusmody form.

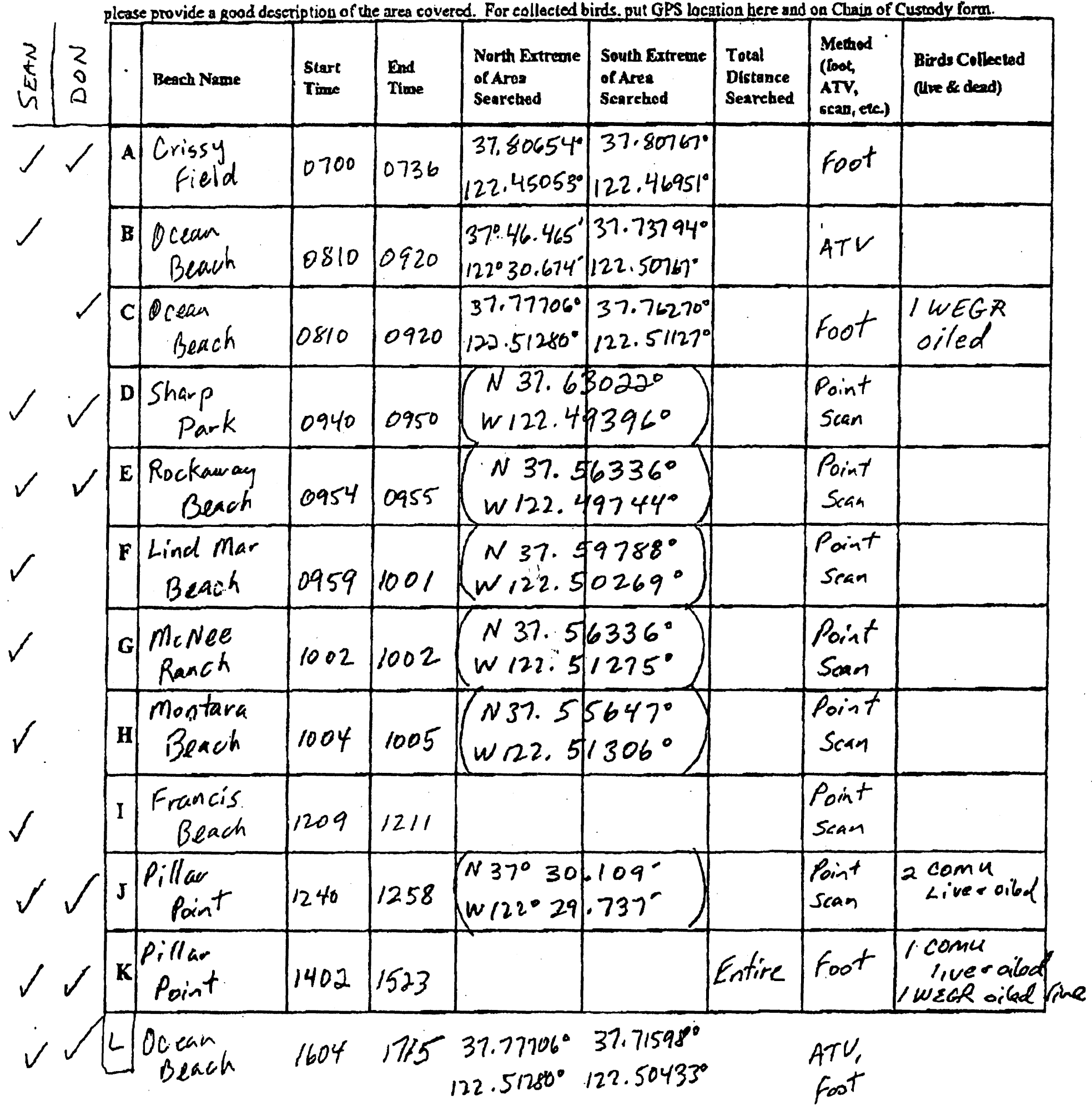



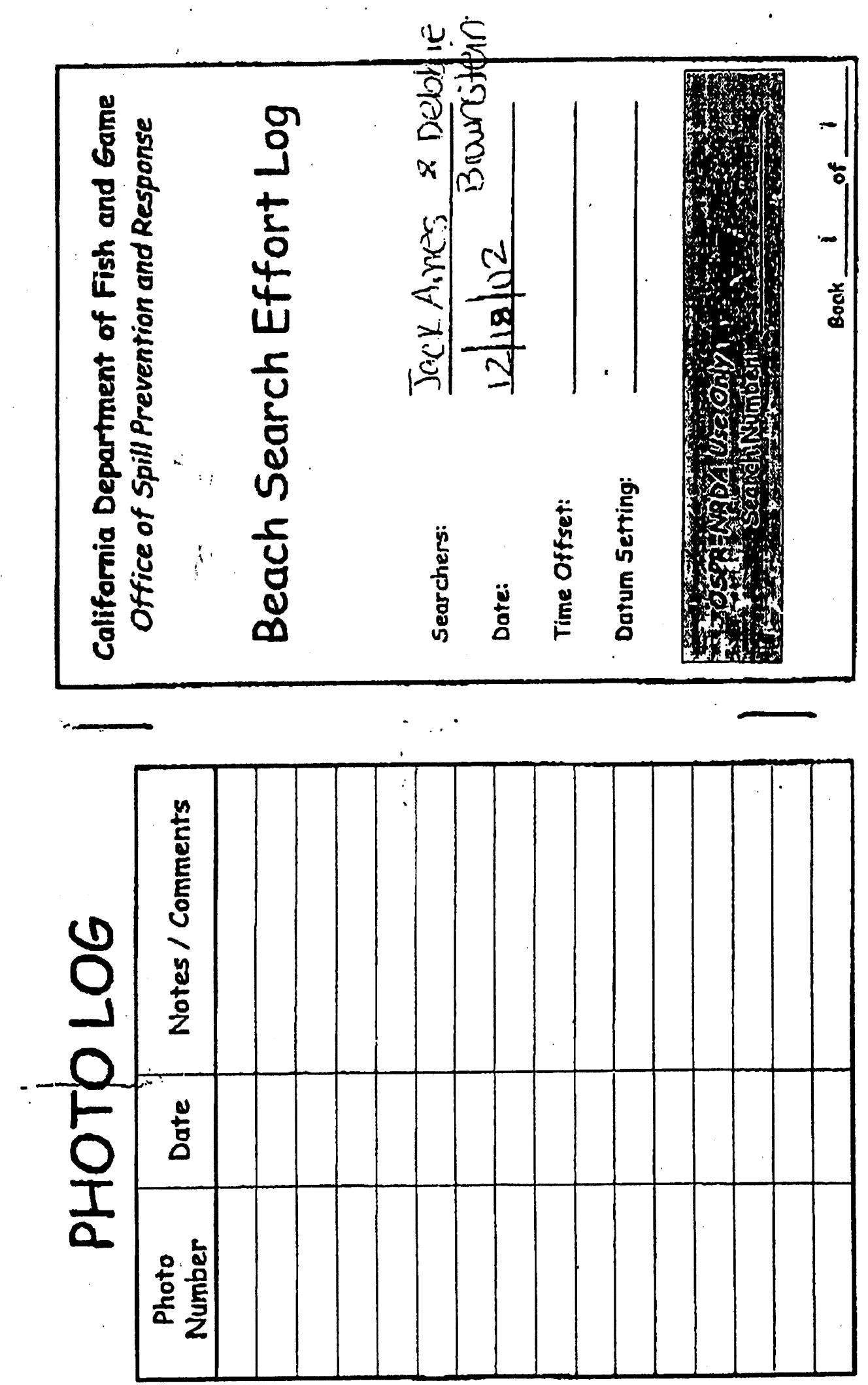


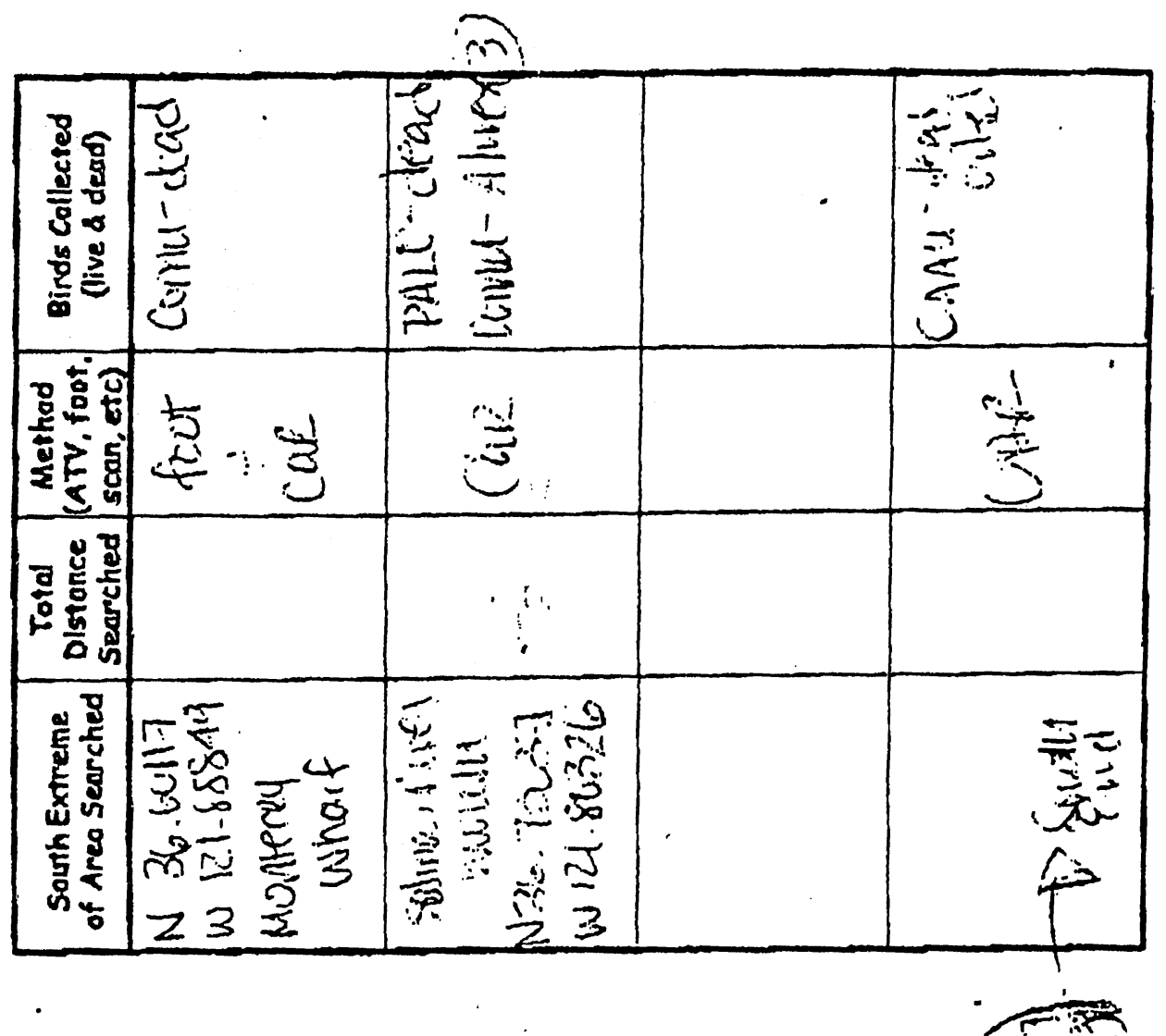

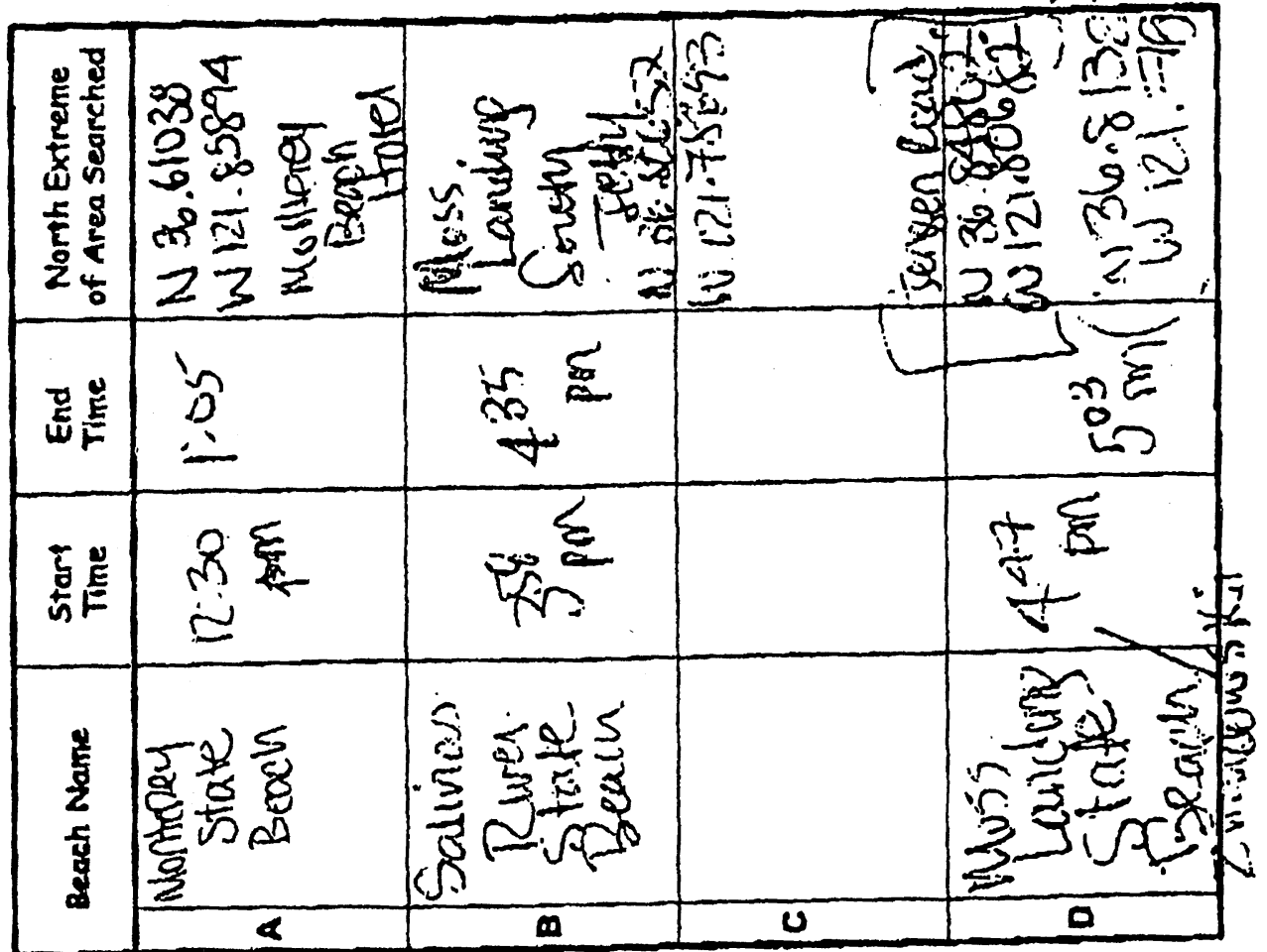


$12 / 21 / 2002$

$20: 28$

INTI BIRD RESCUE RESEARCH .COIR $\rightarrow 1916.5248429$

Bryant Austin - Search Effort Log 621-02 .doc

Search Number:

Beach Search Effort Log

$3 \%$

Please record all beaches searched even if no birds are found.

Spill Name: Luckenbach

$$
\text { Date: } 12-18-02
$$

Searchers: Wendy Samgracamo/Hanjer Griehl

Note: Time should include all time spent on the beach, even when backtracking. North and south endpoints should be GPS pts. If nos, please provide a goad description of the area covered. For collected birds. put GPS location here and on Chain of Custody form.

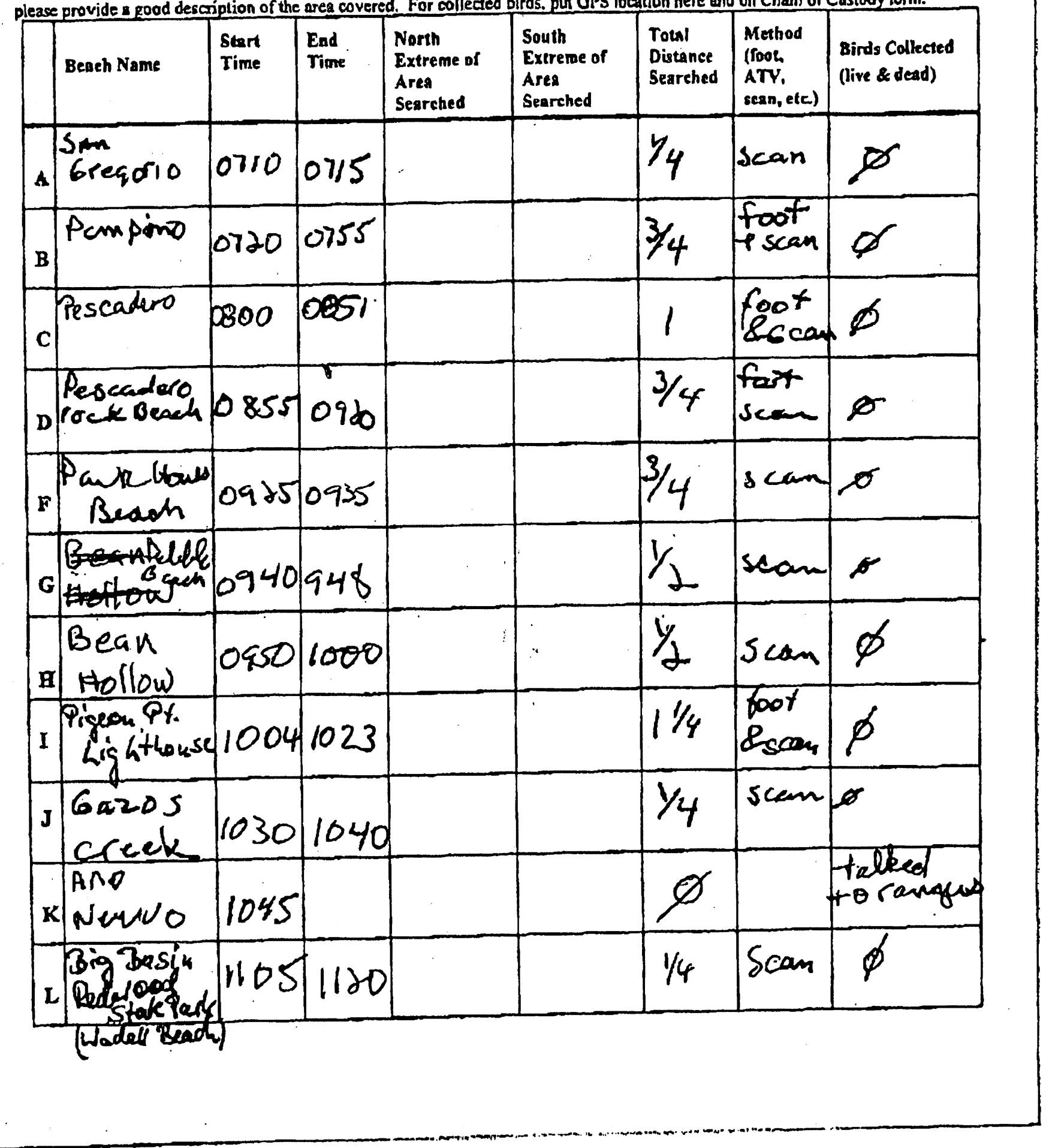




\section{Beach Search Effort Log}

Search Number:

Please record all beaches searched even if no birds are found.

Spill Name: Luchearhach

Searchers: Sanquecomo /6rwhl

Date: $12-18-02$

Nate: Time should include all time spent on the beach, even when backeracking. North and south endpoints should be GPS pts. If not, please provide a good descriprion of the arca covered. For collected birds. pur GPS location here and on Chain of Custody form.

\begin{tabular}{|c|c|c|c|c|c|c|c|c|}
\hline & Beach Name & $\begin{array}{l}\text { Start } \\
\text { Time }\end{array}$ & $\begin{array}{l}\text { End } \\
\text { Time }\end{array}$ & \begin{tabular}{|l} 
Narth \\
Extreme of \\
Area \\
Searched \\
\end{tabular} & $\begin{array}{l}\text { South } \\
\text { Extreme of } \\
\text { Arres } \\
\text { Searched } \\
\end{array}$ & $\begin{array}{l}\text { Total } \\
\text { Distance } \\
\text { Searched }\end{array}$ & $\begin{array}{l}\text { Method } \\
\text { (foot, } \\
\text { ATV, } \\
\text { scar, erc.) } \\
\end{array}$ & $\begin{array}{l}\text { Birds Collected } \\
\text { (live \& dead) }\end{array}$ \\
\hline A & $\begin{array}{l}\text { South of } \\
\text { wablep } \\
\text { Beach }\end{array}$ & 1140 & $\begin{array}{l}\text { ws1.04 } \\
w 122 .\end{array}$ & $\begin{array}{l}530 \\
2760\end{array}$ & & $1 / 2$ & $\sec x$ & \\
\hline B & 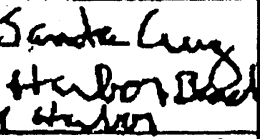 & 1205 & 1330 & & & $1 \cdot 5$ & walt & $\varnothing$ \\
\hline c & $\begin{array}{l}\text { Seadrugt } \\
\text { Beach }\end{array}$ & 1340 & 1420 & & & I aule & walk & $\varepsilon$ \\
\hline D & & & & & & & & \\
\hline $\mathbf{F}$ & & & & & & & & \\
\hline G & & & & & & & & \\
\hline E) & & & & & $\therefore$ & & & \\
\hline I & & & & & & & & \\
\hline $\mathbf{J}$ & & & & & & & & \\
\hline $\mathbf{K}$ & & & & - & & & & \\
\hline $\mathbf{L}$ & & & & & & & & \\
\hline
\end{tabular}


$\int^{01 / 22 / 2003}$

$10: 44$

$5307523318 \rightarrow 919163248829$

(43)

(30)

- S: Crave Hampton

$3 c$

Fr: Mike Ziccand:

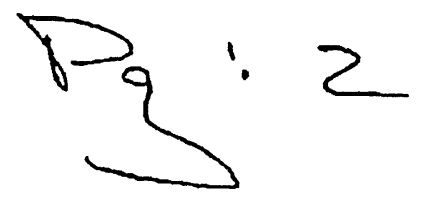

PHOTO LOG

\begin{tabular}{|l|l|l|}
\hline $\begin{array}{c}\text { Photo } \\
\text { Number }\end{array}$ & Date & Notes / Comments \\
\hline & & \\
\hline & & \\
\hline & & \\
\hline & & \\
\hline & & \\
\hline & & \\
\hline & & \\
\hline & & \\
\hline & & \\
\hline & & \\
\hline & & \\
\hline & & \\
\hline & & \\
\hline
\end{tabular}

California Department of Fish and Game Office of Spill Prevention and Response

TorS Waypoint Logbook Spill / Project Name:

Sim Matio:My Spill Operator Name: BALLACD/RYSSEll GPS Unit Serial No.: Date Checked Out: Date Returned: DaserTimo Downloaded: Downloaded By.

Book of 

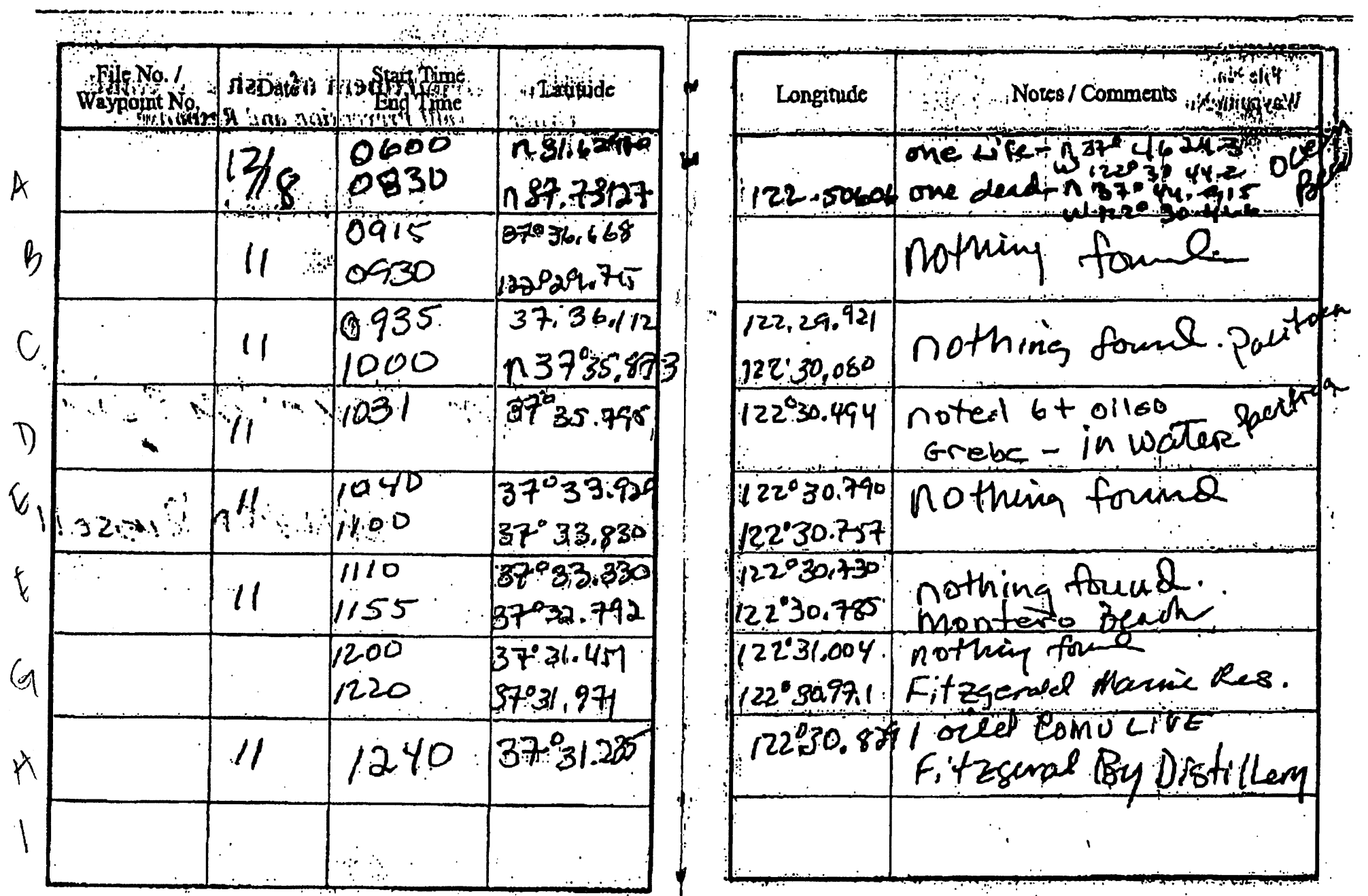


\section{Beach Search Effort Log}

Please record all beaches searched even if no birds are found.

Search Number.

spill Name: Luckew bach

Date: $12 / 18 / 02$

searchers: Deirdre A. Goodfrewd

Note. Time sbould include all time speat on the beach, even when backeracking. North nad south eadpoints strould be GPS pts. If aot. please provide a good description of the area covered. For collected binds. pur GPS location here and on Chain of Custody form.

\begin{tabular}{|c|c|c|c|c|c|c|c|c|}
\hline . & Bcach Name & $\begin{array}{l}\text { Start } \\
\text { Trme }\end{array}$ & $\begin{array}{l}\text { Dad } \\
\text { Time }\end{array}$ & $\begin{array}{l}\text { North Extreme } \\
\text { of Area } \\
\text { Searched }\end{array}$ & $\begin{array}{l}\text { South Extreme } \\
\text { of Aney } \\
\text { Searched }\end{array}$ & $\begin{array}{l}\text { Total } \\
\text { Distance } \\
\text { Searched }\end{array}$ & $\begin{array}{l}\text { Method } \\
\text { (foot, } \\
\text { ATV, } \\
\text { seso, ete) }\end{array}$ & $\begin{array}{l}\text { Birds Collextod } \\
\text { (the \& dad) }\end{array}$ \\
\hline $\mathbf{A}$ & Stinson Bch & $10: 30$ & 1115 & $\begin{array}{l}75 y e d s(0) \\
\text { of coptum } \\
\text { pet. }\end{array}$ & $\begin{array}{l}50 \text { yds (5) } \\
\text { of axptume } \\
\text { pet. }\end{array}$ & $\sim / 25 \times 4$ & $5 \cos \theta$ & $\begin{array}{l}\text { WEGR } \\
W 37.89655 \\
W 122.62560\end{array}$ \\
\hline B & $\begin{array}{l}A=t_{c} B_{c h} \\
\left(c_{0} . b_{c e c}\right)\end{array}$ & $1 / 35$ & 1150 & $\begin{array}{l}\text { viewed } \\
\text { from } \\
\text { accares }\end{array}$ & $\begin{array}{l}\text { viewed } \\
\text { frow } \\
\text { cueses }\end{array}$ & $\sim 10$ ya. & sean & \\
\hline$C$ & $\begin{array}{l}\text { Strusan } \\
\text { Bct. }\end{array}$ & 1225 & 1240 & $\begin{array}{l}75 y d \cdot 0) \\
\text { of coptinc } \\
\text { Gec } A)\end{array}$ & $\begin{array}{l}\text { Soyds (S) } \\
\text { of coptione } \\
\text { (sec A) }\end{array}$ & $2 / 253 d_{s}$ & senes & \\
\hline D & $\begin{array}{l}\text { Mcdure } \\
\text { Bet. }\end{array}$ & 1340 & 1435 & $\begin{array}{l}\text { vicued } \\
\text { from } \\
\text { accesspl }\end{array}$ & $\begin{array}{l}\text { vic wed } \\
\text { frow } \\
\text { acuess pf }\end{array}$ & $\sim{ }_{y}^{300}$ & $\operatorname{sen} w$ & \\
\hline $\mathbf{E}$ & $\begin{array}{l}\text { Nowh } \\
\text { Bet }\end{array}$ & 1545 & 1610 & $\begin{array}{l}v i r \text { wed } \\
\text { fiom } \\
N 38.0774\end{array}$ & $122.574 / 3$ & $\sim 200$ & Scosurated & \\
\hline$F$ & $\begin{array}{l}\text { South } \\
\text { Beach }\end{array}$ & 1623 & 1648 & $\begin{array}{r}\text { viewade } \\
\text { w } 38.04878 \\
w 122.987\end{array}$ & $\begin{array}{l}\text { from } \\
26\end{array}$ & $\begin{array}{l}-306 \\
\text { yrdos }\end{array}$ & $\operatorname{sen} \cos ^{-}$ & \\
\hline$G$ & & & & & & & & \\
\hline $\mathbf{H}$ & & & & & & & & \\
\hline I & & & & & & & & \\
\hline $\boldsymbol{J}$ & & & & & & & & \\
\hline & & & & & & & & \\
\hline
\end{tabular}




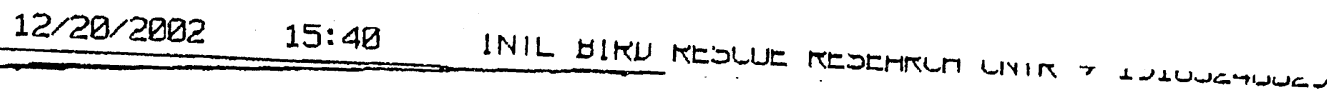

Search Number:

Beach Search Effort Log

Please record all beaches searched even if no birds are found.

Spill Name: SS JLuckenbach

Date: $12 / 18 / 02^{26}$

Searchers: SmcAllister/D. Goodfriend

Note: Time should include all time spent on the beach, eves when backtracking. North and south endpoints.should be GPS pts. If not, please provide a good description of the area covered. For collected birds, put G.PS location here and on Chain of Custody form.

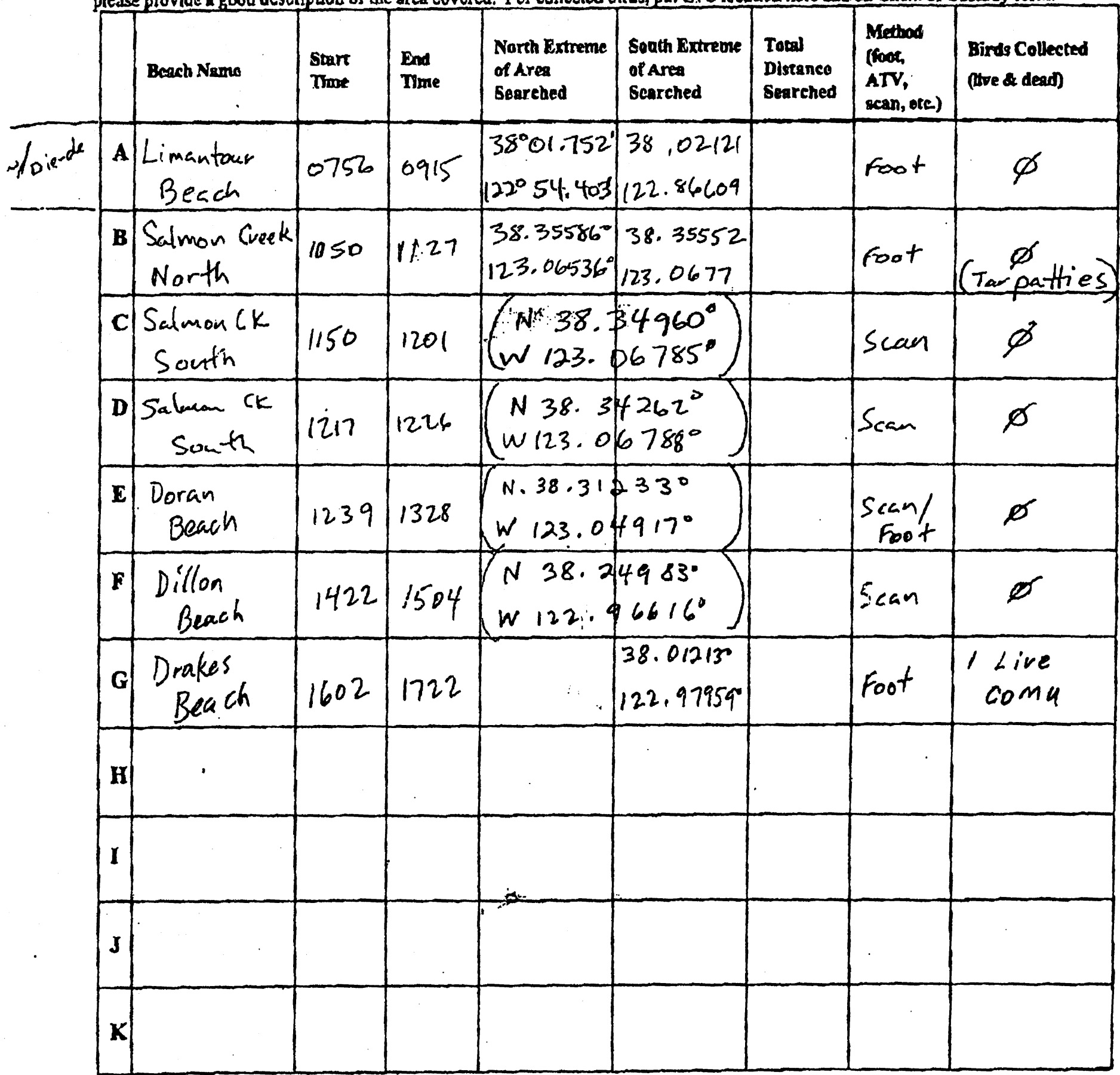




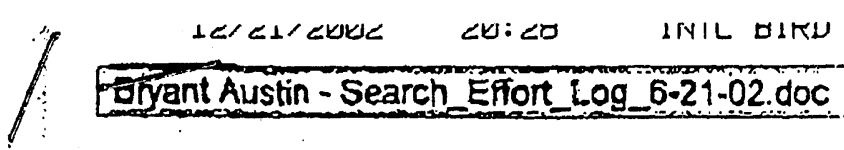

Beach Search Effort Log

Search Number:

Please record all beaches searched even if no birds are found.

Spill Name: Luckenblach.

Date: $12-17-02$

Searchers: Sanquacomo/6riehl

Nate: Time should include all time spent on the beach, even when backtracking. North and south endpoints should be GPS pts. If not. please provide e good description of the area covered. For collected birds. put GPS location here and on Chain of Custody form.

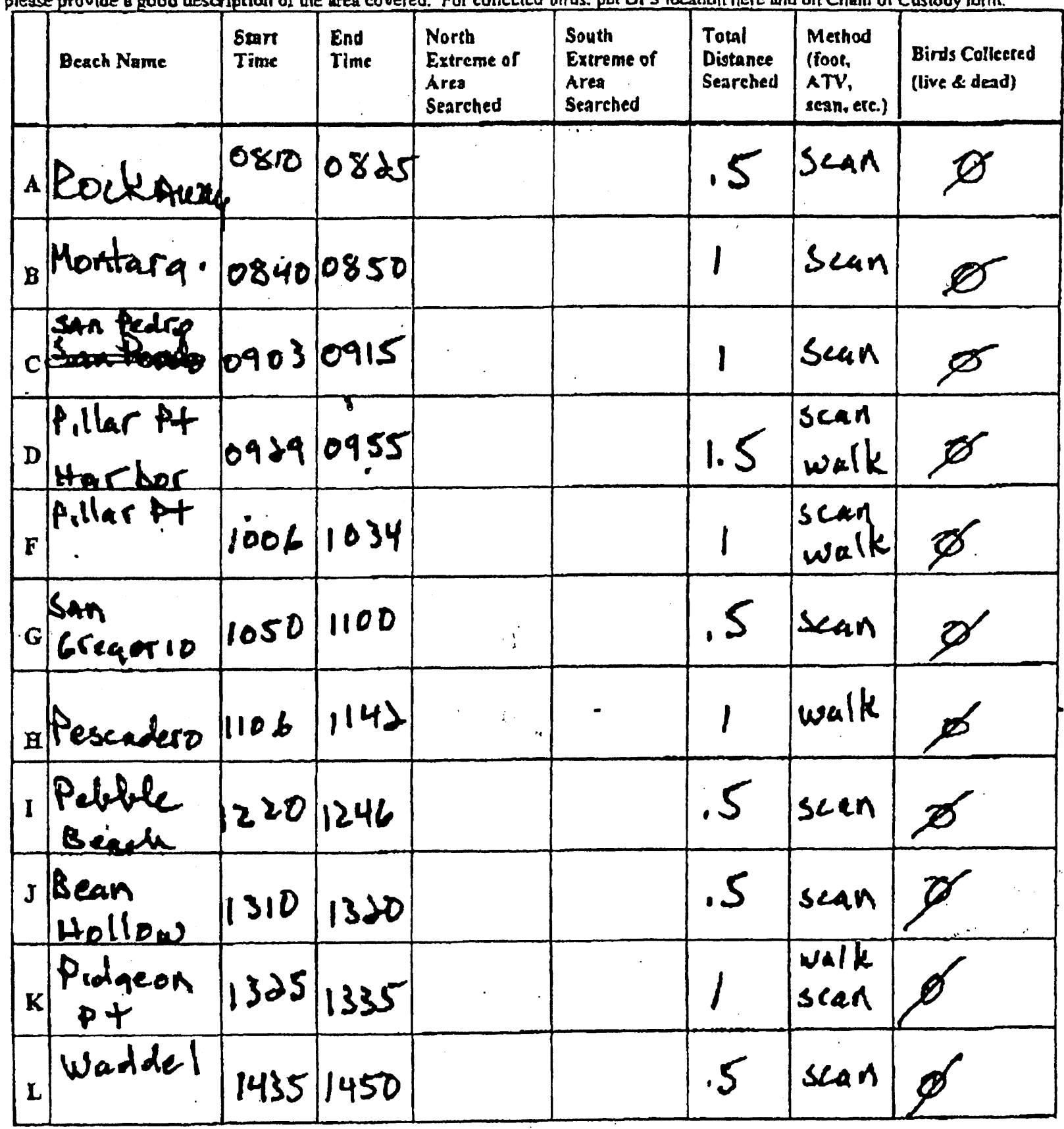


s

$21 / 2002 \quad 20: 28$

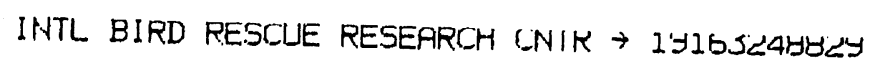

it Austin - Search Effort_Log_6-21-02.doc

Search Number:

Beach Search Effort Log

Please record all beaches searched even if no birds ore found.

Spill Name _Luekentach

Date: $12-1702$

searchers: Sanqsacamo/ bricks

Note: Time should include all time spent on the beach, even when backtracking. North and south endpoints should be GPS pes. If not please provide a good description of the area covered. For collected birds. pun GPS location here and on Chain af Custody forms.

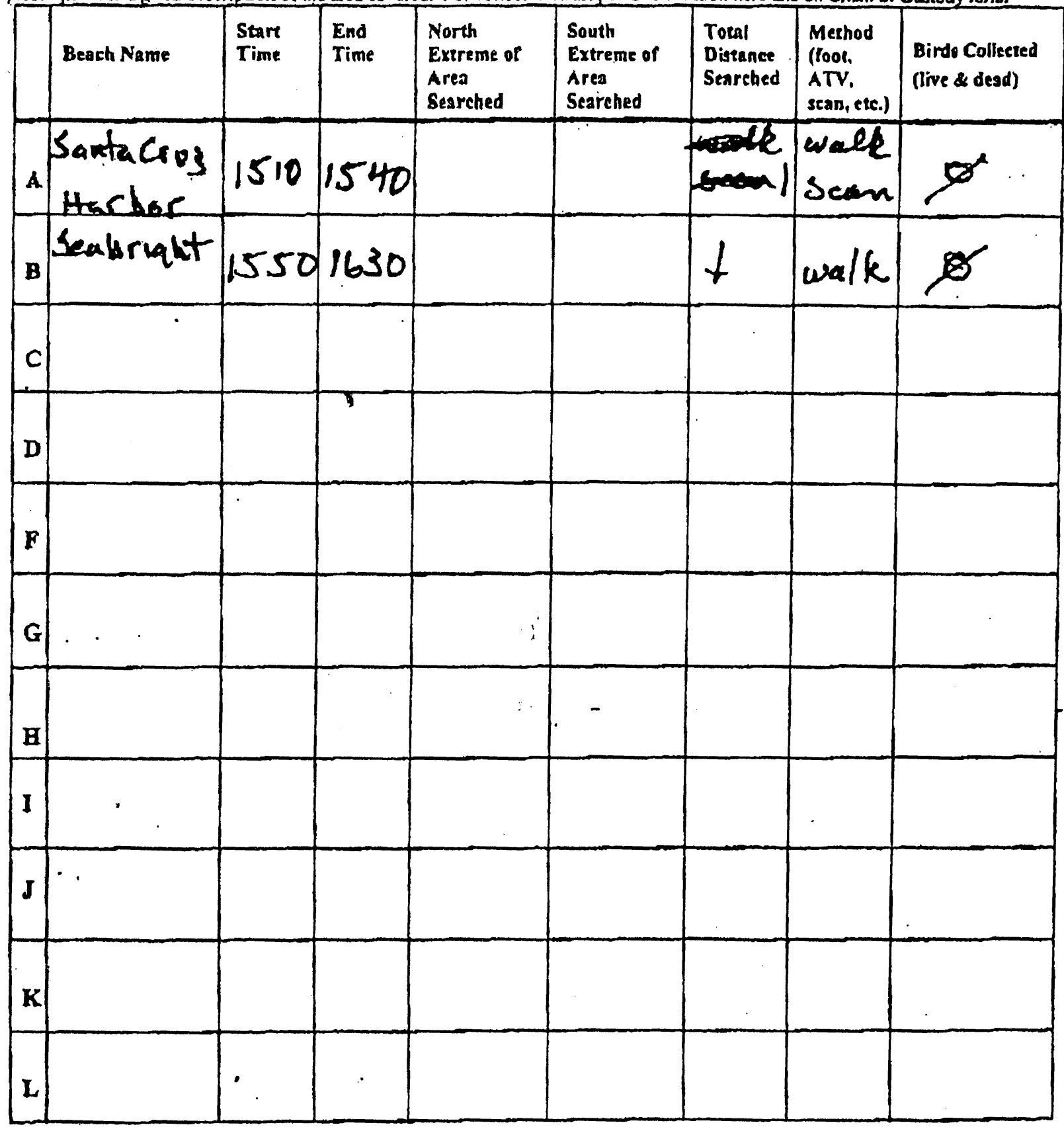




\section{APPENDIX B}

\section{Summary of Raw Beach Search Effort Data}




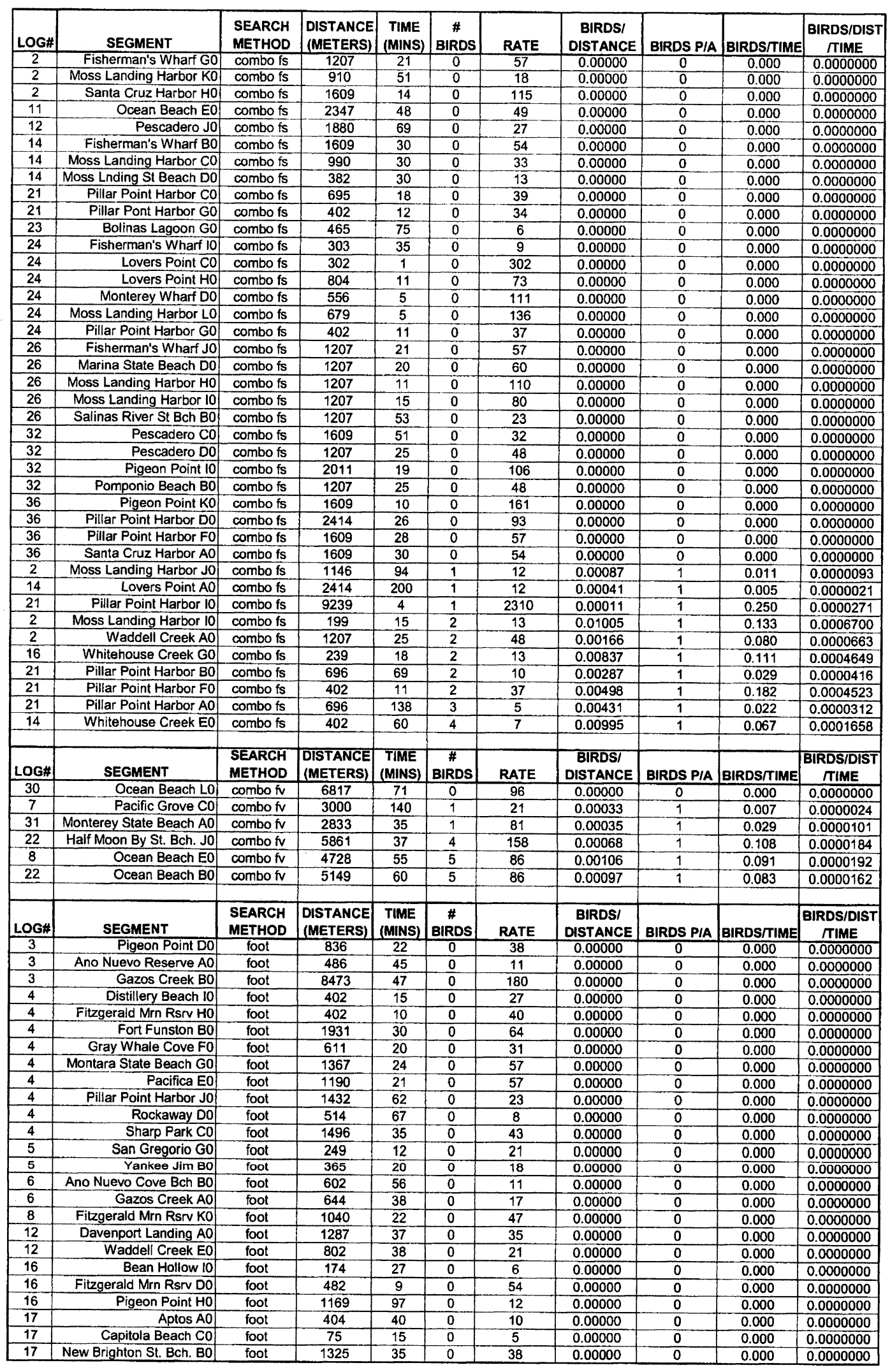




\begin{tabular}{|c|c|c|c|c|c|c|c|c|c|c|}
\hline LOG\# & \begin{tabular}{l|} 
SEGMENT \\
\end{tabular} & $\begin{array}{l}\text { SEARCH } \\
\text { METHOD } \\
\end{array}$ & $\begin{array}{l}\text { DISTANCE } \\
\text { (METERS) }\end{array}$ & $\begin{array}{c}\text { TIME } \\
\text { (MINS) }\end{array}$ & $\begin{array}{c}\# \\
\text { BIRDS } \\
\end{array}$ & RATE & $\begin{array}{c}\text { BIRDSI } \\
\text { DISTANCE } \\
\end{array}$ & BIROS PIA & BIRDS/TIME & $\begin{array}{c}\text { BIRDS/DIST } \\
\text { TIME }\end{array}$ \\
\hline 17 & Seabright Beach EO & foot & 139 & 20 & 0 & 7 & 0.00000 & 0 & 0.000 & 0.0000000 \\
\hline 18 & Pebble Beach $\mathrm{HO}$ & foot & 401 & 30 & 0 & 13 & 0.00000 & 0 & 0.000 & 0.0000000 \\
\hline 18 & Pebble Beach 10 & foot & 838 & 3 & 0 & 279 & 0.00000 & 0 & 0.000 & 0.0000000 \\
\hline 20 & Dillon Beach DO & foot & 325 & 24 & 0 & 14 & 0.00000 & 0 & 0.000 & 0.0000000 \\
\hline 22 & Gray Whale Cove Fo & foot & 208 & 11 & 0 & 19 & 0.00000 & 0 & 0.000 & 0.0000000 \\
\hline 22 & Sharp Park CO & foot & 317 & 12 & 0 & 26 & 0.00000 & 0 & 0.000 & 0.0000000 \\
\hline 25 & Crissy Field AO & foot & 1609 & 34 & 0 & 47 & 0.00000 & 0 & 0.000 & 0.0000000 \\
\hline 26 & Moss Landing Harbor $\mathrm{BO}$ & foot & 4023 & 15 & 0 & 268 & 0.00000 & 0 & 0.000 & 0.0000000 \\
\hline 29 & San Gregorio AO & foot & 182 & 20 & 0 & 9 & 0.00000 & 0 & 0.000 & 0.0000000 \\
\hline 30 & Crissy Field AO & foot & 1675 & 36 & 0 & 47 & 0.00000 & 0 & 0.000 & 0.0000000 \\
\hline 32 & Santa Cruz Harbor BO & foot & 2414 & 85 & 0 & 28 & 0.00000 & 0 & 0.000 & 0.0000000 \\
\hline 32 & Seabright Beach CO & foot & 1609 & 40 & 0 & 40 & 0.00000 & 0 & 0.000 & 0.0000000 \\
\hline 33 & EO & foot & 113 & 20 & 0 & 6 & 0.00000 & 0 & 0.000 & 0.0000000 \\
\hline 33 & Fitzgerald Mrn Rsv G0 & foot & 53136 & 20 & 0 & 2657 & 0.00000 & 0 & 0.000 & 0.0000000 \\
\hline 33 & Lindamar $\mathrm{CO}$ & foot & 300 & 25 & 0 & 12 & 0.00000 & 0 & 0.000 & 0.0000000 \\
\hline 33 & Montara State Beach Fo & foot & 598 & 45 & 0 & 13 & 0.00000 & 0 & 0.000 & 0.0000000 \\
\hline 35 & Limantour Beach AO & foot & 4828 & 79 & 0 & 61 & 0.00000 & 0 & 0.000 & 0.0000000 \\
\hline 35 & Salmon Creek BO & foot & 207 & 37 & 0 & 6 & 0.00000 & 0 & 0.000 & 0.0000000 \\
\hline 36 & Pescadero HO & foot & 1609 & 36 & 0 & 45 & 0.00000 & 0 & 0.000 & 0.0000000 \\
\hline 36 & Seabright Beach BO & foot & 1609 & 40 & 0 & 40 & 0.00000 & 0 & 0.000 & 0.0000000 \\
\hline 1 & $\begin{array}{r}\text { Drakes } \\
\end{array}$ & foot & 2916 & 115 & 1 & 25 & 0.00034 & 1 & 0.009 & 0.0000030 \\
\hline 3 & Bean Hollow EO & foot & 670 & 50 & 1 & 13 & 0.00149 & 1 & 0.020 & 0.0000299 \\
\hline 5 & Pescadero EO & foot & 1677 & 36 & 1 & 47 & 0.00060 & 1 & 0.028 & 0.0000166 \\
\hline 8 & Baker Beach BO & foot & 1126 & 38 & 1 & 30 & 0.00089 & 1 & 0.026 & 0.0000234 \\
\hline 8 & Crissy Field CO & foot & 1675 & 18 & 1 & 93 & 0.00060 & 1 & 0.056 & 0.0000332 \\
\hline 12 & Franklin Point Fo & foot & 567 & 54 & 1 & 11 & 0.00176 & 1 & 0.019 & 0.0000327 \\
\hline 23 & Doran Spit Bodega 10 & foot & 3066 & 131 & 1 & 23 & 0.00033 & 1 & 0.008 & 0.0000025 \\
\hline 26 & Lucas Point LO & foot & 1609 & 95 & 1 & 17 & 0.00062 & 1 & 0.011 & 0.0000065 \\
\hline 30 & Ocean Beach CO & foot & 1598 & 70 & 1 & 23 & 0.00063 & 1 & 0.014 & 0.0000089 \\
\hline 6 & Wadell Creek CO & foot & 1777 & 117 & 2 & 15 & 0.00113 & 1 & 0.017 & 0.0000096 \\
\hline 25 & Pillar Point Harbor Ko & foot & 4828 & 88 & 2 & 55 & 0.00041 & 1 & 0.023 & 0.0000047 \\
\hline 26 & Lovers Point KO & foot & 2414 & 110 & 2. & 22 & 0.00083 & 1 & 0.018 & 0.0000075 \\
\hline 6 & Three Mile Beach GO & foot & 483 & 18 & 3 & 27 & 0.00621 & 1 & 0.167 & 0.0003451 \\
\hline 12 & Scotts Creek BO & foot & 1002 & 30 & 3 & 33 & 0.00299 & 1 & 0.100 & 0.0000998 \\
\hline 20 & Salmon Creek South BO & foot & 539 & 82 & 3 & 7 & 0.00557 & 1 & 0.037 & 0.0000679 \\
\hline 25 & Ocean Beach BO & foot & 1598 & 31 & 3 & 52 & 0.00188 & 1 & 0.097 & 0.0000606 \\
\hline 29 & Santa Cruz City Beach Fo & foot & 137 & 50 & 3 & 3 & 0.02190 & 1 & 0.060 & 0.0004380 \\
\hline 1 & Limantour Spit & foot & 4828 & 275 & 4 & 18 & 0.00083 & 1 & 0.015 & 0.0000030 \\
\hline 19 & Stinson Beach AO & foot & 4303 & 274 & 4 & 16 & 0.00093 & 1 & 0.015 & 0.0000034 \\
\hline 20 & Doran Spit Bodega AO & foot & 1609 & 125 & 4 & 13 & 0.00249 & 1 & 0.032 & 0.0000199 \\
\hline 20 & Salmon Creek North Co & foot & 643 & 81 & 5 & 8 & 0.00778 & 1 & 0.062 & 0.0000960 \\
\hline 23 & Stinson Beach AO & foot & 228 & 235 & 6 & 1 & 0.02632 & 1 & 0.026 & 0.0001120 \\
\hline 4 & Ocean Beach A0 & foot & 4828 & 115 & 11 & 42 & 0.00228 & 1 & 0.096 & 0.0000198 \\
\hline 15 & Limantour $\mathrm{AO}$ & foot & 2234 & 225 & 21 & 10 & 0.00940 & 1 & 0.093 & 0.0000418 \\
\hline 10 & Limantour Spit BO & foot & 5471 & 284 & 26 & 19 & 0.00475 & 1 & 0.092 & 0.0000167 \\
\hline LOG\# & SEGMENT & $\begin{array}{l}\text { SEARCH } \\
\text { METHOD } \\
\end{array}$ & \begin{tabular}{|l|} 
DISTANCE \\
(METERS) \\
\end{tabular} & \begin{tabular}{|c|} 
TIME \\
(MINS) \\
\end{tabular} & $\begin{array}{c}\# \\
\text { BIRDS } \\
\end{array}$ & RATE & $\begin{array}{c}\text { BIRDSI } \\
\text { DISTANCE }\end{array}$ & BIRDS PIA & BIRDSTIME & $\begin{array}{c}\text { BIRDS/DIST } \\
\text { TIME }\end{array}$ \\
\hline 2 & Greyound Rock B0 & scan & 1207 & 7 & 0 & 172 & 0.00000 & 0 & \begin{tabular}{|l|}
0.000 \\
\end{tabular} & 0.0000000 \\
\hline 2 & Scotts Creek Co & scan & 402 & 6 & 0 & 67 & 0.00000 & 0 & 0.000 & 0.0000000 \\
\hline 12 & Pebble Beach KO & scan & 46 & 8 & 0 & 6 & 0.00000 & 0 & 0.000 & 0.0000000 \\
\hline 17 & Cowell Beach HO & scan & 300 & 5 & 0 & 60 & 0.00000 & 0 & 0.000 & 0.0000000 \\
\hline 17 & Schwan Lagoon DO & scan & 300 & 22 & 0 & 14 & 0.00000 & 0 & 0.000 & 0.0000000 \\
\hline 24 & Fisherman's Wharf Bo & scan & 804 & 7 & 0 & 115 & 0.00000 & 0 & 0.000 & 0.0000000 \\
\hline 24 & Monterey Harbor AO & scan & 804 & 9 & 0 & 89 & 0.00000 & 0 & 0.000 & 0.0000000 \\
\hline 24 & Moss Landing Harbor Jo & scan & 314 & 11 & 0 & 29 & 0.00000 & 0 & 0.000 & 0.0000000 \\
\hline 25 & Montara State Beach GO & scan & 1229 & 3 & 0 & 410 & 0.00000 & 0 & 0.000 & 0.0000000 \\
\hline 26 & Moss Landing Harbor Fo & scan & 1207 & 8 & 0 & 151 & 0.00000 & 0 & 0.000 & 0.0000000 \\
\hline 26 & Moss Landing Harbor GO & scan & 1207 & 5 & 0 & 241 & 0.00000 & 0 & 0.000 & 0.0000000 \\
\hline 26 & Salinas River Harbor CO & scan & 1207 & 15 & 0 & 80 & 0.00000 & 0 & 0.000 & 0.0000000 \\
\hline 27 & Pigeon Point BO & scan & 1104 & 23 & 0 & 48 & 0.00000 & 0 & 0.000 & 0.0000000 \\
\hline 28 & Bean Hollow B0 & scan & 66 & 11 & 0 & 6 & 0.00000 & 0 & 0.000 & 0.0000000 \\
\hline 28 & Waddell Creek AO & scan & 137 & 17 & 0 & 8 & 0.00000 & 0 & 0.000 & 0.0000000 \\
\hline 32 & Bean Hollow HO & scan & 804 & 10 & 0 & 80 & 0.00000 & 0 & 0.000 & 0.0000000 \\
\hline 32 & Gazos Creek Jo & scan & 402 & 10 & 0 & 40 & 0.00000 & 0 & 0.000 & 0.0000000 \\
\hline 32 & Pebble Beach Fo & scan & 1207 & 10 & 0 & 121 & 0.00000 & 0 & 0.000 & 0.0000000 \\
\hline 32 & Pebble Beach GO & scan & 804 & 8 & 0 & 101 & 0.00000 & 0 & 0.000 & 0.0000000 \\
\hline 32 & San Gregorio AO & scan & 402 & 5 & 0 & 80 & 0.00000 & 0 & 0.000 & 0.0000000 \\
\hline 32 & Waddell Creek AO & scan & 804 & 25 & 0 & 32 & 0.00000 & 0 & 0.000 & 0.0000000 \\
\hline 32 & Waddell Creek LO & scan & 402 & 15 & 0 & 27 & 0.00000 & 0 & 0.000 & 0.0000000 \\
\hline 34 & Ano Nuevo Cove Bch BO & scan & 91 & 15 & 0 & 6 & 0.00000 & 0 & 0.000 & 0.0000000 \\
\hline 34 & McClures Beach D0 & scan & 274 & 55 & 0 & 5 & 0.00000 & 0 & 0.000 & 0.0000000 \\
\hline 34 & North Beach & scan & 182 & 25 & 0 & 7 & 0.00000 & 0 & 0.000 & 0.0000000 \\
\hline 34 & South Beach & scan & 274 & 17 & 0 & 16 & 0.00000 & 0 & 0.000 & 0.0000000 \\
\hline 34 & Stinson Beach Co & scan & 114 & 15 & 0 & 8 & 0.00000 & 0 & 0.000 & 0.0000000 \\
\hline 36 & Bean Hollow J0 & scan & 804 & 10 & 0 & 80 & 0.00000 & 0 & 0.000 & 0.0000000 \\
\hline
\end{tabular}




\begin{tabular}{|c|c|c|c|c|c|c|c|c|c|c|}
\hline LOG\# & SEGMENT & $\begin{array}{l}\text { SEARCH } \\
\text { METHOD } \\
\end{array}$ & \begin{tabular}{|l} 
DISTANCE \\
(METERS)
\end{tabular} & $\begin{array}{c}\text { TIME } \\
\text { (MINS) }\end{array}$ & $\begin{array}{c}\# \\
\text { BIRDS } \\
\end{array}$ & RATE & $\begin{array}{c}\text { BIRDS/ } \\
\text { DISTANCE }\end{array}$ & BIRDS PIA & BIRDS/TIME & $\begin{array}{c}\text { BIRDS/DIST } \\
\text { TIME }\end{array}$ \\
\hline 36 & Lindamar C0 & scan & 1609 & 12 & 0 & 134 & 0.00000 & 0 & 0.000 & 0.0000000 \\
\hline 36 & Montara State Beach B0 & scan & 1609 & 10 & 0 & 161 & 0.00000 & 0 & 0.000 & 0.0000000 \\
\hline 36 & Pebble Beach 10 & scan & 804 & 26 & 0 & 31 & 0.00000 & 0 & 0.000 & 0.0000000 \\
\hline 36 & Rockaway A0 & scan & 804 & 15 & 0 & 54 & 0.00000 & 0 & 0.000 & 0.0000000 \\
\hline 36 & San Gregorio Go & scan & 804 & 10 & 0 & 80 & 0.00000 & 0 & 0.000 & 0.0000000 \\
\hline 36 & Waddell Creek LO & scan & 804 & 15 & 0 & 54 & 0.00000 & 0 & 0.000 & 0.0000000 \\
\hline 26 & Moss Landing Harbor $\mathrm{AO}$ & scan & 1609 & 25 & 1 & 64 & 0.00062 & 1 & 0.040 & 0.0000249 \\
\hline 34 & Stinson Beach $\mathrm{AO}$ & scan & 114 & 45 & 1 & 3 & 0.00877 & 1 & 0.022 & 0.0001949 \\
\hline LOG\# & SEGMENT & $\begin{array}{l}\text { SEARCH } \\
\text { METHOD }\end{array}$ & \begin{tabular}{|l|} 
DISTANCE \\
(METERS)
\end{tabular} & $\begin{array}{l}\text { TIME } \\
\text { (MINS) }\end{array}$ & \begin{tabular}{|c|}
$\#$ \\
BIRDS \\
\end{tabular} & RATE & $\begin{array}{c}\text { BIRDS/ } \\
\text { DISTANCE }\end{array}$ & BIRDS PIA & BIRDSTIME & $\begin{array}{c}\text { BIRDSIDIST } \\
\text { TIME }\end{array}$ \\
\hline 7 & Lovers Point BO & vehicle & 30 & 5 & 0 & 6 & 0.00000 & 0 & 0.000 & 0.0000000 \\
\hline 17 & Santa Cruz City Beach Fo & vehicle & 484 & 32 & 0 & 15 & 0.00000 & 0 & 0.000 & 0.0000000 \\
\hline 30 & Ocean Beach BO & vehicle & 35127 & 70 & 0 & 502 & 0.00000 & 0 & 0.000 & 0.0000000 \\
\hline 18 & Ocean Beach B0 & vehicle & 4613 & 11 & 2 & 419 & 0.00043 & 1 & 0.182 & 0.0000394 \\
\hline 11 & Half Moon Bay GO & vehicle & 6204 & 17 & 4 & 365 & 0.00064 & 1 & 0.235 & 0.0000379 \\
\hline
\end{tabular}




\section{APPENDIX C}

Map of Beach Segments Searched 


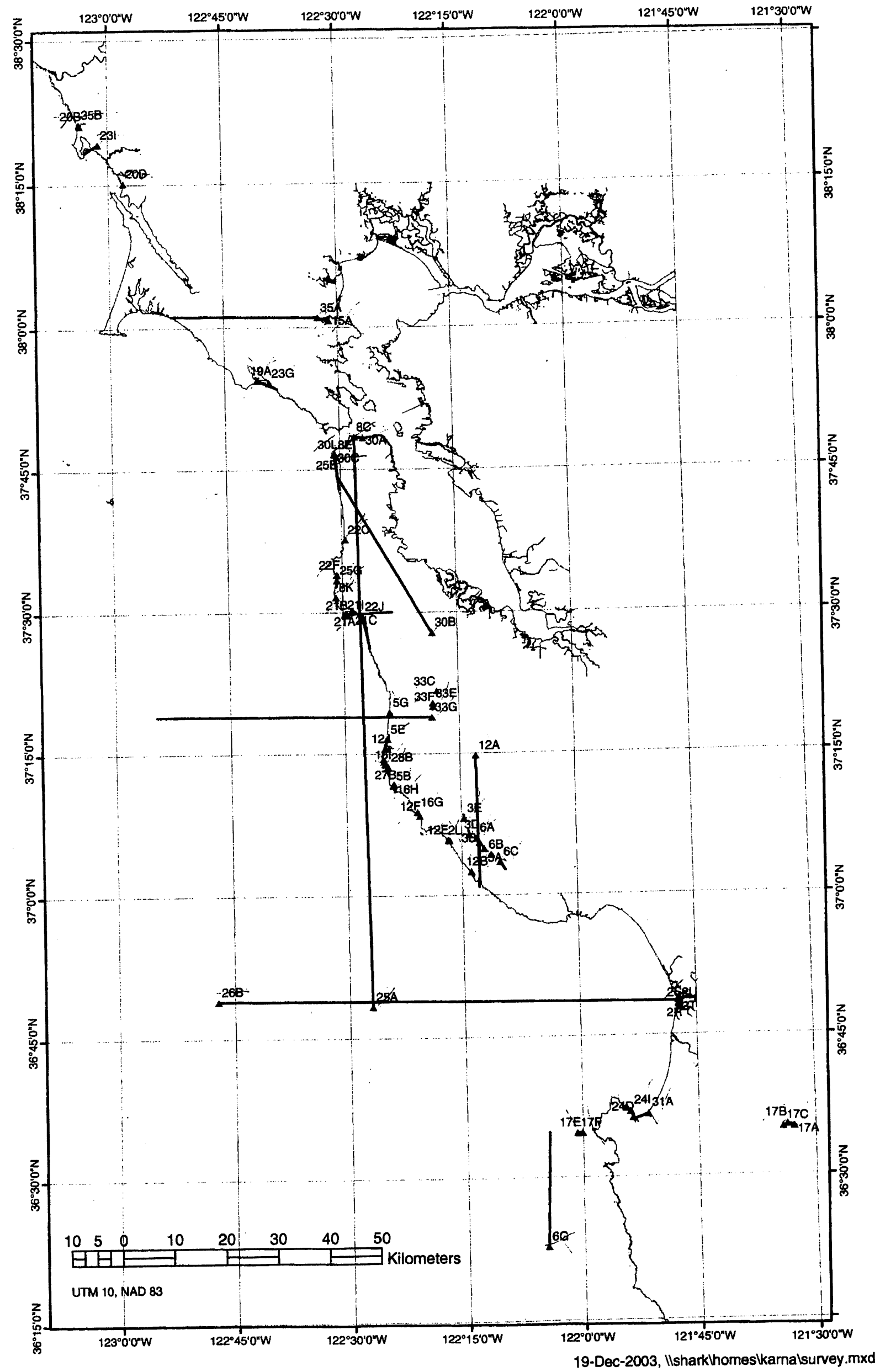

